\title{
DEMOCRACIA ROMANTIZADA, FRAGMENTAÇÃo POLÍTICA E O DECLÍNIO DO GOVERNO NORTE-AMERICANO*
}

RICHARD PILDES ${ }^{\dagger}$

RESUMO: A romantização democrática norte-americana contribui para a disfuncionalidade das instituições de seu governo, ou, ao menos, é o que alega este artigo. Três linhas de pensamentos que modelam esse argumento são desenvolvidas. Primeiro, para entender a paralisia do atual governo norte-americano, é tão importante focar o problema da "fragmentação política", quanto a extrema polarização dos partidos políticos. Por fragmentação, compreendo a difusão interna do poder político que se distancia das lideranças partidárias e se aproxima das mãos de seus membros individualmente, mas também a difusão externa do poder, distanciando-se dos partidos em direção a organizações nãopartidárias. A polarização política de hoje é um produto de um processo

* [N.T] Traduzido para o português, com a autorização do autor, por Aline Brayner e revisado por Igor de Lazari, do texto Romanticizing Democracy, Political Fragmentation, and the Decline of American Government, originalmente produzido em língua inglesa, apresentado na Palestra Ralph Gregory Elliot (2013-2014), da Yale Law School, e publicado no Yale Law Journal, Vol. 124, 3, 2014. Aline Brayner é Graduanda em Direito pela Universidade Federal do Rio de Janeiro (UFRJ) e Pesquisadora do Laboratório de Estudos Teóricos e Analíticos sobre Comportamento das Instituições (LETACI). Email: alinebrayner@outlook.com. Igor de Lazari é mestrando pelo Programa de PósGraduação em Direito (PPGD) da Universidade Federal do Rio de Janeiro (UFRJ) e Pesquisador do Laboratório de Estudos Teóricos e Analíticos sobre o Comportamento das Instituições (LETACI). E-mail: rogi.242006@hotmail.com.

${ }^{\dagger}$ Professor Sudler Family de Direito Constitucional da New York University School of Law. Eu sou grato por comentários recebidos na palestra e durante a apresentação dessas visões no Workshop da NYU. Eu também gostaria de agradecer Hélène Landemore e Nick Stephanopoulos por comentários. Pela excelente assistência na pesquisa, eu agradeço a Nabil Ansari, assim como à equipe de referências da biblioteca de NYU, particularmente a Gretchen Feltes. Eu também devo pelas discussões tidas com Senadores e membros da Câmara aposentados, todos os quais exigiram anonimato. 
histórico de longo prazo e possivelmente duradouro; como resultado, acordos que atravessam linhas partidárias são mais prováveis de vir de líderes de partidos, que possuem o forte incentivo de manter a legenda partidária atraente ao maior eleitorado possível. Mas líderes de partidos só conseguem fazer isso se puderem pressionar seus membros recalcitrantes a se juntar ao acordo; a fragmentação política torna isso mais difícil de se alcançar. Além disso, a revolução das comunicações e a captação de fundos online agora permite que os representantes funcionem mais como empresários independentes do que no passado. Segundo, a ímpar cultura democrática e o desenho institucional norte-americanos contribuem para a fragmentação política. Nosso sistema é muito mais individualista e populista, em sua estrutura, do que o de outras democracias maduras. Leis de financiamento de campanhas, por exemplo, são mais baseadas na ideia de um sistema de eleições individualista e centrado no candidato, do que naquela em que as organizações centrais da política - os partidos políticos - desempenham um papel central. Na particular versão norte-americana da "responsabilidade democrática", nossos mandatários estão sujeitos a eleições mais frequentes, contemplando-se as primárias, do que representantes eleitos em qualquer outro lugar; nós elegemos muito mais agentes, incluindo-se juízes e promotores, do que qualquer outro país; muitos de nossos esforços para reformas políticas perseguem um maior papel participativo de cidadãos individualmente. Grande parte das atuais propostas para mudar o financiamento de campanhas eleitorais, por exemplo, busca fortalecer "pequenos doadores" ou conceder vouchers a cidadãos, individualmente, que eles podem usar para financiar candidatos. Porém, há motivos para temer que tais práticas alimentarão a fragmentação política e dificultarão a governança efetiva, à medida que doações individuais tendem a desaguar em candidatos ideologicamente mais extremos e polarizados. Terceiro, uma direção distinta para reforma buscaria fortalecer as forças do centrismo e focar mais o poder de organizações do que o poder de indivíduos. Para resistir à fragmentação política, esforços para reforma podem procurar fortificar o papel de partidos políticos e líderes de partidos, de modo que membros 
individualmente terão menos do que um efetivo poder de veto. Este artigo sugere várias políticas específicas diferentes na área do financiamento de campanhas eleitorais que podem fazer isso ao conferir um papel mais relevante aos partidos políticos no sistema de financiamento de campanhas.

PalaVRas-Chave: Direito Constitucional; Teoria Democrática;

Partidos Políticos; Financiamento de Campanhas Eleitorais; Polarização.

ABSTRACT: American democratic romanticism contributes to the current dysfunctionality of the institutions of American government, or so this article argues. Three lines of thought are developed that shape this argument. First, to understand the paralysis of current American government, it is as important to focus on the problem of "political fragmentation" as on the extreme polarization of the political parties. By fragmentation, I mean both the internal diffusion of political power away from the party leadership into the hands of individual members, and the external diffusion of power away from the parties to non-party organizations. Today's political polarization is a product of long-term historical processes and likely to be enduring; as a result, deals across party lines are most likely to come from party leaders, who have the strongest incentive to make the party label attractive to the largest electorate. But party leaders can do so only if they can press their recalcitrant members to join the deal; political fragmentation makes that more difficult to achieve. And the communications revolution and online fundraising now enable individual officeholders to function more as independent entrepreneurs than in the past. Second, America's unique democratic culture and institutional design contribute to political fragmentation. Our system is much more individualistic and populist in structure than that of other mature democracies. Campaign finance laws, for example, are based on the idea of an individualistic, candidatecentered system of elections, rather than one in which the central organizations of politics - the political parties - play a central role. In the 
particular American version of "democratic accountability," our officeholders are subject to more frequent elections, including primaries, than elected officials elsewhere; we elect vastly more officials, including judges and prosecutors, than any other country; much of our political reform efforts seek a greater participatory role for the individual citizen. Many current proposals for changing campaign finance, for example, seek to empower "small donors," or to give individual citizens vouchers they can use to fund candidates. But reason exists for concern that doing so will fuel political fragmentation and make effective governance more difficult, to the extent individual donations are likely to flow to more ideologically extreme, polarizing candidates. Third, a different direction for reform would seek to empower the forces of centrism and to focus more on organizational power in politics than on individuals. To resist political fragmentation, reform efforts can seek to strengthen the role of political parties and party leaders, so that individual members will have less of an effective veto power. This article suggests several different specific policies in the campaign finance area that might do so by giving political parties a greater role in the campaign finance system.

KEYWORDS: Constitutional Law; Democratic Theory; Political Parties; Electoral Campaign Finance; Polarization. 


\section{SUMÁRIO:}

I. INTRODUÇão .......................................................................................272

II. FRAGMENTAÇÃo POLÍTICA …………………………………………......275

III. ROMANTISMO DEMOCRÁTICO...........................................................227

IV. AS CAUSAS DA POLARIZAÇão...........................................................287

V. PODER POLÍtICO, PARTIDOS POLÍTICOS.............................................301

VI. DECLÍNIO ESTRUTURAL NO PODER DOS LÍDERES PARTIDÁRIOS ....307

VII. UM SISTEMA DE FINANCIAMENTO DE CAMPANHA BASEADO EM PARTIDOS ..........................................................................311

VIII.TORNANDO AS NEGOCIAÇÕES POSSÍVEIS............................................323

IX. VISÕES MENOS ROMANTIZADAS DA DEMOCRACIA ...........................329

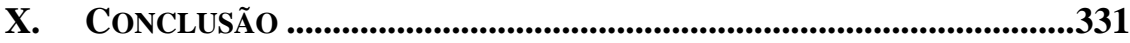

XI. REFERÊNCIAS.............................................................................................332

\section{TABLE OF CONTENTS:}

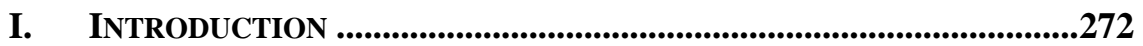

II. POLITICAL FRAGMENTATION...........................................................275

III. DEMOCRATIC ROMANTICISM ...........................................................277

IV. THE CAUSES OF POLARIZATION ..............................................................287

V. POLITICAL POWER, POLITICAL PARTIES .......................................301

VI. STRUCTURAL DECLINE IN THE POWER OF PARTY LEADERS .............307

VII. A PARTY-BASED CAMPAIGN FINANCE SYSTEM ....................................311

VIII.MAKING DEAL-MAKING POSSIBLE ................................................323

IX. LESS ROMANTICIZED VISIONS OF DEMOCRACY .................................329

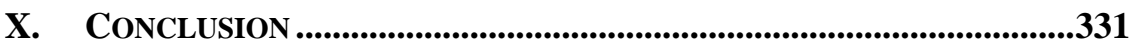

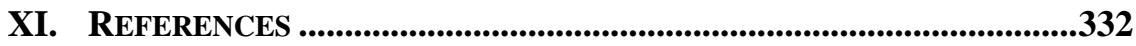




\section{INTRODUÇÃO}

Há muitos anos tenho interesse em desenvolver uma perspectiva mais institucionalista e mais realista sobre a dinâmica da democracia e do poder político, particularmente nos Estados Unidos. Nesse sentido, refiro-me à organização sistêmica do poder político e às formas pelas quais as doutrinas jurídicas e seus moldes, assim como as estruturas institucionais, determinam os modos pelos quais o poder político é efetivamente mobilizado, organizado e encorajado ou desencorajado. Esta perspectiva enfatiza, entre outros elementos, os processos dinâmicos através dos quais as coligações vencedoras são construídas ou destruídas nas esferas das eleições e da governança. A relação mutuamente influente entre essas esferas determina, em última instância, as formas pelas quais nossas instituições democráticas funcionam ou deixam de funcionar.

Esse foco na organização, estrutura e exercício do poder político nas eleições e na governança é o que, em minha opinião, caracteriza o "direito da democracia" - um campo sistemático de estudo nas escolas de direito nos últimos vinte anos. ${ }^{1}$ Para reforçar essa descrição inicial, eu compararia o enfoque do "direito da democracia" com aquelas abordagens ao direito e à teoria constitucional que se concentram na proteção e no desenvolvimento da dignidade, da autonomia ou da "personalidade" do indivíduo, e garantem a igualdade de tratamento dos grupos particularmente vulneráveis. Estas são as aspirações de Taking Rights Seriously, por exemplo - o título do livro que define a abordagem de alguém que tem estado muito em minha mente ultimamente, meu colega, falecido recentemente, Ronald Dworkin. ${ }^{2}$

No entanto, quero contrastar o meu foco na organização sistêmica do poder político às abordagens orientadas para os direitos aplicadas à

${ }_{1}^{1}$ Para meu desenvolvimento mais amplo dessa perspectiva, cf. PILDES, Richard. Foreword: The Constitutionalization of Democratic Politics. Harvard Law Review, Vol. 118, 29, 2004. A primeira edição do livro de casos The Law of Democracy: Legal Structure of the Political Process, de minha coautoria com meus amigos e colegas de trabalho Sam Issacharoff and Pam Karlan foi publicada em 1998. Cf. ISSACHAROFF, Samuel; KARLAN, Pamela; PILDES, Richard. The Law of Democracy: Legal Structure of the Political Process. Westbury, NY: Foundation Press, 1998. Ao longo deste ensaio, e em toda minha obra, eu permaneço profundamente em débito tanto a Sam, quanto a Pam. Para uma boa revisão histórica da matéria, cf. GERKEN, Heather. What Election Law Has to Say to Constitutional Law? Indiana Law Review, Vol. 44, 1, 2011.

2 DWORKIN, Ronald. Taking Rights Seriously. Cambridge, MA: Harvard University Press, 1977. 
própria democracia. ${ }^{3}$ Por abordagens voltadas para os direitos, refiro-me a abordagens que se concentram em interpretar e elaborar em termos normativos ou doutrinários, os valores gerais, amplos e políticos da democracia, como participação, deliberação, igualdade política e liberdade ou os direitos legais associados à associação política, à liberdade de expressão, ao voto, ou à igualdade política. Essas abordagens orientadas para os direitos geralmente prestam menos atenção às consequências estruturais ou sistêmicas - os efeitos sobre a organização do poder político - de institucionalizar concretamente esses ideais abstratos em contextos específicos. As perspectivas orientadas para os direitos também muitas vezes repousam, implicitamente, numa concepção de democracia que considera os cidadãos individuais como os atores políticos centrais. Podemos ver essas abordagens na doutrina constitucional, na defesa reformista sobre a democracia e na erudição sobre a democracia na teoria política, na filosofia e no direito. ${ }^{4}$ Minha

${ }^{3}$ Em Politics as Markets: Partisan Lockups of the Democratic Process, Sam Issacharoff e eu descrevemos esse foco na organização sistêmica do poder político enquanto uma perspectiva estrutural do direito da democracia. Cf. ISSACHAROFF, Samuel; PILDES, Richard. Politics as Markets: Partisan Lockups of the Democratic Process. Stanford Law Review, Vol. 50, 3, 1998. Em particular, nós enfatizamos o valor sistêmico da promoção de competitividade em políticas democráticas como um valor estrutural central que deve informar as leis da política. Cf. ISSACHAROFF, Samuel; PILDES, Richard. Politics as Markets: Partisan Lockups of the Democratic Process. Stanford Law Review, Vol. 50, 3, 1998, p. 646-648. Cf., ainda, PILDES, Richard. The Theory of Political Competition, Virginia Law Review, Vol. 85, 8, 1999 (elaborando a perspectiva estrutural). Para uma crítica da perspectiva estrutural e um endosso de uma perspectiva mais tradicional e orientada por direitos acerca desta questão, cf. HASEN, Richard. The Supreme Court and Election Law: Judging Equality from Baker v. Carr to Bush v. Gore. New York, NY: New York University Press, 2003, p. 143-156. Para uma revisão perspicaz do debate entre análises estruturais e orientadas por direitos, acerca de questões jurídicas concernentes à organização da democracia, cf. CHARLES, Guy-Uriel. Judging the Law of Politics. Michigan Law Review, Vol. 103, 6, 2005 (resenha de HASEN, Richard. The Supreme Court and Election Law: Judging Equality from Baker v. Carr to Bush v. Gore. New York, NY: New York University Press, 2003).

${ }^{4}$ Como eu já afirmei anteriormente, a aproximação da Corte de casos envolvendo reivindicações de direitos concernentes ao processo democrático, frequentemente, "é convencional porque importa, adentro do direito da democracia, os mesmos instrumentos dogmáticos, testes jurídicos, e formas de enquadramento das questões de áreas mais plenamente desenvolvidas do direito constitucional...". PILDES, Richard. Competitive, Deliberative, and Rights-Oriented Democracy. Election Law Journal: 
sugestão, no entanto, é que essas abordagens podem gerar doutrinas e políticas que minam a capacidade do sistema democrático de funcionar como um todo de maneira eficaz. Em vez desta orientação baseada em direitos, meu foco é sobre como o poder político se mobiliza, se organiza e funciona (ou se rompe). ${ }^{5}$

No presente artigo, adaptado de uma palestra que dei na Faculdade de Direito de Yale em novembro de 2013, vou ilustrar essa abordagem com um problema presente em nossas mentes, o que o título chama de “O Declínio do Governo Americano". Ao fazer essa declaração, quero apelar para um amplo consenso de tal declínio. Portanto, não me refiro especificamente a uma incapacidade de agir em áreas de conflito partidário em que uma das partes tem uma preferência política substantiva pelo status quo (política de mudança climática, por exemplo). Em vez disso, eu me refiro a arenas onde existe um amplo acordo

Rules, Politics, and Policy, Vol. 3, 4, 2004 (resenha de POSNER, Richard. Law, Pragmatism, and Democracy. Cambridge, MA: Harvard University Press, 2003). Para exemplos específicos dentro do direito constitucional, cf. PILDES, Richard. Foreword: The Constitutionalization of Democratic Politics. Harvard Law Review, Vol. 118, 29, 2004, p. 101-130. Para semelhantes críticas recentes da Corte por falhar ao reconhecer que a interpretação dos "direitos" da democracia devem derivar de uma concepção estrutural subjacente quanto ao propósito do sistema democrático como um todo, cf. HELLMANN, Deborah. Defining Corruption and Constitutionalizing Democracy. Michigan Law Review, Vol. 111, 8, 2013.

${ }_{5}^{5}$ Para exemplos dessa perspectiva aplicada à Voting Rights Act, em que eu enfatizo a importância de focar mais coalizões políticas vencedoras em formação capazes de exercer verdadeiro poder governamental do que o aumento da representação de grupos minoritários, cf. PILDES, Richard. Political Competition and the Modern VRA. In: David Epstein, et. al. (eds.). The Future of the Voting Rights Act. New York, NY: Russell Sage Foundation, 2006, p. 1-19; PILDES, Richard. Is Voting-Rights Law Now at War with Itself? Social Science and Voting Rights in the 2000s. North Carolina Law Review, Vol. 80, 5, 2002; e PILDES, Richard. The Politics of Race. Harvard Law Review, Vol. 108, 6, 1995 (resenha de DAVIDSON, Chandler; GROFMAN, Bernard. (eds.). Quiet Revolution in the South: the Impact of the Voting Rights Act, 19651990. Princeton, NJ: Princeton University Press, 1994). Para uma visão similar, cf. ISSACHAROFF, Samuel. Is Section 5 of the Voting Rights Act a Victim of Its Own Success? Columbia Law Review, Vol. 104, 6, 2004. Para visões dissidents, cf. GERKEN, Heather. Second-Order Diversity. Harvard Law Review, Vol. 118, 4, 2005; KANG, Michael. Race and Democratic Contestation. Yale Law Journal, Vol. 117, 5, 2008; e KARLAN, Pamela. Georgia v. Ashcroft and the Retrogression of Retrogression. Election Law Journal: Rules, Politics, and Policy, Vol. 3, 1, 2004. 
consensual de que o governo deve agir de alguma forma, mas onde o governo americano agora parece incapaz de fazê-lo - ou onde o governo age, mas somente depois de trazer o país ou o mundo à beira de um precipício: encerramento do governo, a dança regular na borda da faca do primeiro governo dos EUA padrão, e assim por diante. Eu não quero sugerir que o governo americano está em algum estado de crise extrema. A democracia americana enfrentou desafios muito mais dramáticos antes $^{6}$ e, como observadores democráticos de Tocqueville até hoje reconheceram, a democracia raramente é "tão ruim quanto parece" em qualquer momento em particular. ${ }^{7}$ É suficiente reconhecer uma séria disfunção, mesmo em áreas particulares, para motivar a busca por explicações mais profundas, bem como direções para possíveis caminhos adiante.

\section{FRAGMENTAÇÃO POLÍTICA}

Eu quero oferecer duas ideias principais sobre como pensar o declínio da capacidade de governança e eficácia dos Estados Unidos.

Em primeiro lugar, quero sugerir que não podemos entender como nossas instituições democráticas são projetadas e como elas funcionam sem reconhecer que uma sensibilidade e uma compreensão culturais exclusivamente americanas da democracia - que eu vejo como

6 Para uma consideração mobilizadora do poderoso desafio que estilos autoritários de governo tiveram de enfrentar, na década de 1930, para a democracia desejada nos Estados Unidos, e mais amplamente, cf. KATZNELSON, Ira. Fear Itself: The New Deal and the Origins of our Time. New York, NY: Liveright Publishing Corp., 2014, p. 3-58.

7 RUNCIMAN, David. The Confidence Trap: a History of Democracy in Crisis from World War I to the Present. Princeton, NJ: Princeton University Press, 2013, p. 2. Para uma discussão das visões de Tocqueville sobre como democracias deveriam ser entendidas para responder a crises, cf. RUNCIMAN, David. The Confidence Trap: a History of Democracy in Crisis from World War I to the Present. Princeton, NJ: Princeton University Press, 2013, p. 1-34. Em nota similar, enquanto reconhece que o governo norte-americano está atualmente passando por uma era de "disfunção sustentada", Jack Balkin alega que isso é melhor compreendido como um período de "transição constitucional", em que o novo "regime constitucional" substituirá, eventualmente, o presente e o novo não mais parecerá ser disfuncional. Cf. BALKIN, Jack. The Last Days of Disco: Why the American Political System Is Dysfunctional. Boston University Law Review, Vol. 94, 3, 2014. 
excessivamente romântica, particularmente nas formas que toma hoje demonstram uma boa parte das maneiras como projetamos e reformamos nossas instituições democráticas. Creio que essa concepção exclusivamente romântica da democracia contribuiu perversamente para o declínio de nossas instituições políticas formais. Isto será um dos meus temas: os perigos do romantismo democrático.

Em segundo lugar, ao diagnosticar as causas da capacidade limitada do governo para funcionar efetivamente, há uma tendência generalizada de focar no quão polarizados os dois partidos políticos dominantes tornaram-se (bem como sobre se a polarização é assimétrica entre os dois partidos). ${ }^{8}$ Muitos comentários sobre a polarização focam na dificuldade de encaixar partidos políticos americanos cada vez mais parlamentares numa constituição cuja arquitetura institucional é de um sistema de separação de poderes..$^{9}$ A preocupação compreensível que muitos têm hoje em dia é se em tempos de governo dividido - mas não só depois, dada a regra de obstrução do Senado, que permanece no local em questões políticas - a ausência de um "governo majoritário" poderá tornará muito difícil a geração de ação política necessária para a legislação.

Se a preocupação com a polarização for compreendida como uma governança, então talvez devamos refinar a preocupação, particularmente para os pragmáticos que procuram por direções potencialmente produtivas de reformas plausíveis. Para isso, devemos identificar a questão não como polarização política apenas, mas como uma questão de fragmentação política. Por "fragmentação", refiro-me à difusão externa do poder político, que se afasta dos partidos políticos como um todo, e à difusão interna do poder, ou seja, da liderança partidária para os membros do partido. Meu argumento é que, para os reformadores pragmáticos, a fragmentação política dos partidos (mais obviamente visível, no momento, do lado republicano, mas latente também no lado democrata) é um foco de atenção mais importante do que a polarização se quisermos explicar por que a dinâmica da competição partidária paralisa cada vez mais o governo americano. $\mathrm{O}$ shutdown do governo e padrão financeiro não eram um simples produto

${ }^{8}$ Cf., por exemplo, McCARTY, Nolan, et. al.. Polarization is Real (and Asymmetric).

Voteview Blog, May 16, 2012. Disponível em:

$<$ http://themonkeycage.org/2012/05/polarization-is-real-and-asymmetric/>. Acesso em: 14 de agosto de 2017.

${ }^{9}$ Em trabalho anterior, eu contribui para enquadrar a questão nesses termos. Cf., por exemplo, LEVINSON, Daryl; PILDES, Richard. Separation of Parties, Not Powers.

Harvard Law Review, Vol. 119, 8, 2006, p. 2316-2330. 
da polarização partidária; refletiam a incapacidade dos líderes partidários de trazer facções minoritárias recalcitrantes de seus partidos e membros individuais para fazerem os acordos que os líderes partidários acreditavam serem necessários. O problema não é que temos partidos parlamentares. Em vez disso, é possível que nossos partidos políticos não sejam parlamentares - o suficiente: os líderes partidários são agora incapazes de exercer o tipo de liderança partidária efetiva característica dos sistemas parlamentares.

Se esta análise é correta, partidos mais fortes - ou partidos mais fortes em certas dimensões - ironicamente podem ser o veículo mais eficaz para permitir os compromissos e acordos necessários para permitir uma governança mais eficaz, apesar da divisão partidária. Vou oferecer um rápido esboço de algumas propostas de políticas destinadas a reempoderar líderes dos partidos políticos, a fim de tornar o governo mais funcional. Mas as propostas específicas são menos importantes em si mesmas do que como ilustrações de uma direção de reforma que poderia permitir uma governança mais efetiva no contexto duradouro de partidos políticos altamente polarizados.

\section{ROMANTISMO DEMOCRÁTICO}

Deixe-me começar impressionando você sobre a singularidade das práticas americanas e instituições de democracia, tomadas em conjunto, em comparação com as de outras democracias maduras e estáveis.

As reformas da era Jacksoniana nos legaram os únicos juízes eleitos do mundo. ${ }^{10}$ De fato, elegemos mais de 500 mil representantes do

${ }^{10} \mathrm{Na}$ incomparável história norte-americana de juízes eleitos, cf. SHUGERMAN, Jed Handelsman. The People's Courts: Pursuing Judicial Independence in America. Cambridge, MA: Harvard University Press, 2012, p. 5, anotando que "quase ninguém no mundo jamais experimentou a eleição popular de juízes"; e CROLEY, Steven. The Majoritarian Difficulty: Elective Judiciaries and the Rule of Law. University of Chicago Law Review, Vol. 62, 2, 1995. Para uma crítica recente dos Judiciários eleitos, cf. SAMPLE, James, et. al. (eds.). The New Politics of Judicial Elections 2000-2009:

decade of change. Washington, DC: Justice at Stake Campaign, 2010. Para uma defesa, cf. BONNEAU, Chris; GANN HALL, Melinda. In Defense of Judicial Elections. New York, NY: Routledge, 2009. Sobre o papel central de promotores eleitos no níveis estadual e local no sistema de justiça criminal, cf. GARLAND, David. Peculiar Institution: America's Death Penalty in an Age of Abolition. Cambridge, MA: Belknap Press of Harvard University Press, 2010, p. 47-48; STUNTZ, William. The 
executivo e do legislativo, muito mais do que qualquer outro país per capita (um funcionário a cada 485 pessoas): elegemos comissários de seguros, comissários de drenagem, conselhos de hospitais, associações de faculdades comunitárias, conselhos escolares locais e assim por diante. ${ }^{11}$ Além disso, carecemos de instituições independentes para supervisionar o processo eleitoral, tais como tribunais eleitorais especializados, comissões de delimitação de fronteiras independentes e agências independentes - instituições comuns na maioria dos países democráticos. ${ }^{12}$ Isso deixa as autoridades partidárias, eleitas e, em sua maioria, locais em controle de grande parte da regulamentação e administração do processo eleitoral, por uma perversa crença de que fazê-lo torna o processo mais democraticamente responsável perante "nós". ${ }^{13}$

Nosso Estado administrativo, em geral, está muito mais sujeito ao controle democrático do que os de outros países democráticos bem estabelecidos. Embora tenha havido períodos em que abraçamos agências administrativas independentes baseadas em ideais de independência política e especialização, como na Era Progressista e no New Deal, a característica dominante e distinta do governo administrativo americano foi a ênfase no controle político (legislativo ou Executivo) sobre agências administrativas ou o que é muitas vezes chamado de "accountability democrática". ${ }^{14}$ De fato, o crescente ceticismo americano de "expertise" e

Collapse of American Criminal Justice. Cambridge, MA: Belknap Press of Harvard University Press, 2011.

${ }^{11}$ O Censo do Governo de 1992, publicado pelo Departamento de Comércio dos Estados Unidos, fixou o número de agentes eleitos em 513.200, o que traz um agente eleito para cada 485 habitante em 1992. Disponível em:

$<$ https://www.census.gov/prod/2/gov/gc/gc92 1 2.pdf $>$. Acesso em: 14 de agosto de 2017. Agentes federais e estaduais contam para apenas 3,8\% do total. Parece não haver uma versão mais atual deste Censo.

${ }^{12}$ Cf., por exemplo, LEHOUCQ, Fabrice Edouard. Institutionalizing Democracy:

Constraint and Ambition in the Politics of Electoral Reform. Comparative Politics, Vol. 32, 4, 2000; e STEPHANOPOULOS, Nicholas. Our Electoral Exceptionalism.

University of Chicago Law Review, Vol. 80, 2, 2013.

${ }_{13}$ PILDES, Richard. Disputing Elections. In: Arthur Jacobson; Michael Rosenfeld (eds.).

The Longest Night: Polemics and Perspectives on Election 2000. Berkeley, CA: University of California Review, 2002, p. 69; e TOKAJI, Daniel. Responding to Shelby County: A Grand Election Bargain. Harvard Law \& Policy Review, Vol. 8, 1, 2014.

${ }^{14}$ A clássica descrição dessa transformação é STEWART, Richard. The Reformation of American Administrative Law. Harvard Law Review, Vol. 88, 8, 1975, p. 1669, o qual 
pressão por um controle cada vez mais "popular" ou "democrático" de nossas instituições torna duvidoso, na minha opinião, que a força política poderia ser empacotada hoje para criar um sistema bancário central independente, como o Sistema de Reserva Federal criado em 1913, se estivéssemos enfrentando a questão pela primeira vez agora.

De acordo com uma reflexão do grau de controle político sobre a administração pública nos Estados Unidos, existem cerca de 1300 posições do governo federal que exigem a confirmação do Senado, desde a nomeação para a Suprema Corte até a nomeação dos quinze membros do Conselho Nacional de Deficiência, isso sem mencionar a grande quantidade de tempo que os administradores gastam após a nomeação, sujeitos às pressões políticas de uma série de comissões do Congresso. ${ }^{15}$ Como outro exemplo institucional, nossa cultura democrática produziu um sistema bancário extraordinariamente fragmentado durante a maior parte da história americana, de 1830 a 1990. Isso tornou os bancos americanos excepcionalmente instáveis e propensos a crises em relação aos sistemas bancários de alguns outros países democráticos (média de uma crise a cada década). ${ }^{16}$ A compreensão e a política democráticas tornaram nosso sistema bancário exclusivamente sujeito ao controle político local e popular, nossas leis geraram um sistema altamente desagregado e descentralizado de dezenas de milhares de bancos "unitários" (bancos locais individuais, sem ramos) que eram regulados esmagadoramente no nível estadual e, portanto, politicamente controlados por coalizões de banqueiros locais e populistas agrários. De fato, a principal história política dos sistemas bancários em diferentes países caracteriza o sistema bancário americano ao longo do período

\footnotetext{
"traça o desenvolvimento e a desintegração do modelo tradicional" do Direito

Administrativo e sua restituição com o "modelo representativo do interesse emergente" de legitimidade do Estado Administrativo norte-americano.

${ }^{15}$ Para dados sobre o número de posições indicadas presidencialmente e confirmadas pelo Senado (conhecidas como posições "PAS"), cf. LEWIS, David. The Politics of Presidential Appointments: Political Control and Bureaucratic Performance. Princeton, NJ: Princeton University Press, 2008, p. 22-23/81-89/100/203. Cf., também, CAREY, Maeve. Presidential Appointments, The Senate's Confirmation Process, and Changes Made in the 112th Congress. Congressional Research Service, CRS Report 41872, 2012, p. 7 (indicando que havia 1.200-1.400 posições PAS antes das mudanças legislativas de 2012, que eliminaram a confirmação do Senado para 163 dessas posições). ${ }^{16}$ CALOMIRIS, Charles; HABER, Stephen. Fragile by Design: the Political Origins of Banking Crises \& Scarce Credit. Princeton, NJ: Princeton University Press, 2014, p. 168/183/201-202.
} 
1830-1990 como "aleijado pelo populismo". ${ }^{17}$

As reformas da Era Progressista, como a exigência imposta pelo Estado de que os partidos políticos escolham seus candidatos através de eleições primárias, tornaram nossos partidos políticos mais sujeitos ao "controle popular" do que em praticamente qualquer outra democracia. ${ }^{18}$ Consideramos que votamos em candidatos individuais, e não em partidos políticos, e que os partidos devem escolher seus candidatos nas eleições primárias, inclusive para o cargo eleito mais poderoso do mundo. Mas as eleições primárias não são a norma em todo o mundo - os partidos e sua liderança escolhem seus padrinhos em muitas democracias. ${ }^{19}$

${ }^{17}$ CALOMIRIS, Charles; HABER, Stephen. Fragile by Design: the Political Origins of Banking Crises \& Scarce Credit. Princeton, NJ: Princeton University Press, 2014, p. 153-203. Uma estatística impressionante para ilustrar: “Em1914, havia 27.349 bancos nos Estados Unidos, 95\% dos quais não tinham sucursais!" CALOMIRIS, Charles; HABER, Stephen. Fragile by Design: the Political Origins of Banking Crises \& Scarce Credit. Princeton, NJ: Princeton University Press, 2014, p. 181. A proibição de ramificação, que impediu o surgimento de instituições financeiras com proporções nacionais, (como existentes em países com um sistema bancário mais estável, tais como o Canadá) significou que nossos bancos locais não poderiam diversificar amplamente o risco, inclusive cruzando regiões, e tornou as respostas coordenadas entre bancos, durante crises de liquidez, muito mais difíceis. As causas, no final da década de 2000, da pior crise financeira desde a Grande Depressão, após a era da consolidação bancária, iniciada na década de 1990, ainda é muito debatida. Para a visão de Calomiris e Haber sobre isso, cf. CALOMIRIS, Charles; HABER, Stephen. Fragile by Design: the Political Origins of Banking Crises \& Scarce Credit. Princeton, NJ: Princeton University Press, 2014, p. 203-256; para uma revisão recente de alguns livros sobre esse assunto, cf. LEVITIN, Adam. The Politics of Financial Regulation and the Regulation of Financial Politics: A Review Essay. Harvard Law Review, 127, 7, 2014. ${ }^{18}$ Cf. EPSTEIN, Leon. Political Parties in the American Mold. Madison, WI: University of Wisconsin Press, 1986, p. 159-160: “Em nenhum lugar do mundo ocidental democrático, os partidos pareceram tão malignos, ao menos para os cidadãos de classe média, como nos Estados Unidos".

19 Para um breve resumo do enfraquecimento gradual dos partidos políticos norteamericanos desde o Século XIX, cf. JUDIS, John. The Paradox of American Democracy: Elites, Special Interests, and the Betrayal of Public Trust. New York, NY: Pantheon Books, 2000, p. 5-9. Cf., também, SCARROW, Susan, et. al.. From Social Integration to Electoral Contestation: The Changing Distribution of Power within Political Parties. In: Russell Dalton; Martin Watterberg (eds.). Parties without Partisans: Political Change in Advanced Industrial Democracies. Oxford: Oxford University Press, 2002, p. 138141 (listando dados de dezessete democracias, das quais os Estados Unidos são o único 
De fato, nossos partidos são únicos em outras maneiras que refletem nossa compreensão incomum da soberania popular. Nossos partidos têm sido organizações relativamente "esqueléticas" que não exigem o pagamento regular das quotas dos partidos, em contraste com os partidos políticos na maioria dos outros países, assim como a maioria das organizações não partidárias. ${ }^{20}$ Para se "filiar" a um partido nos Estados Unidos basta marcar um " $x$ " em um formulário ou ganhar a votação do partido durante uma eleição primária. A contratação e a demissão de patrocinadores desempenharam um papel análogo ao papel desempenhado pelas cotas de outros países, mas concluímos que isso viola a Primeira Emenda. ${ }^{21} \mathrm{Na}$ ausência de dívidas e o poder da liderança

país permitindo regularmente que não-membros participem de seleção de candidatos e notando que "na seleção de partidos da maioria dos países, o processo permanece largamente desregulado pelas leis que governam cuidadosamente aspectos das eleições públicas"); RAHAT, Gideon. Candidate Selection: The Choice before the Choice. Journal of Democracy, Vol. 18, 1, 2007, p. 161-162 (mecanismos de seleção de candidatos que permitem a participação de todos os eleitores, mesmo aqueles externos ao partido, são utilizados, principalmente, nos Estados Unidos).

${ }^{20}$ EPSTEIN, Leon. Political Parties in the American Mold. Madison, WI: University of Wisconsin Press, 1986, p. 144-147. De fato, porque a Voting Rights Act se aplica a certas ações dos partidos políticos, cf. Morse v. Republican Party of Virginia, 517 U.S. 186 (1996), é concebível que uma cobrança de pagamento de dívida feita por um partido possa ser considerada ilegal imposto de votação. Se Morse sobrevive a decisões posteriores, tais como California Democratic Party v. Jones, 530 U.S. 567 (2000), continua incerto.

${ }^{21}$ Cf. Board of County Commissioners of Wabaunsee v. Umbehr, 518 U.S. 668 (1996) (banindo decisões de patrocinadores pela transferência e pela promoção de trabalhadores independentes); Rutan v. Republican Party of Illinois, 497 U.S. 62 (1990) (fazendo o mesmo para empregados públicos, justificando que "pertencem ao vencedor apenas aqueles despojos que podem ser constitucionalmente obtidos"); cf., ainda, Branti v. Finkel, 445 U.S. 507 (1980) (banindo demissão de patrocinadores onde afiliação partidária não foi exigida para o efetivo exercício da função); Elrod v. Burns, 427 U.S. 347 (1976) (banindo demissão de patrocinadores). Para uma visão dissidente sobre os casos patronais, cf. o argumento do Justice Scalia de que a proibição constitucional sobre o patronato "reflete uma visão ingênua da política e uma apreciação inadequada dos efeitos sistêmicos do patronato ao promover a estabilidade política e facilitar a integração social e política de grupos anteriormente impotentes." Rutan v. Republican Party of Illinois, 497 U.S. 62, 103 (1990), J. Scalia, dissentindo. Justice Scalia alegou em seguida: "Patronato estabiliza partidos políticos e evita excessiva fragmentação política - ambos os quais são resultados em que os Estados têm um forte interesse governamental. A força dos partidos exige esforços dos membros dissidentes, 
partidária de escolherem os candidatos dos partidos, nossos partidos sempre foram menos estruturados do que os das democracias europeias. A disciplina do controle partidário é particularmente firme em países que usam sistemas eleitorais de representação proporcional de fechada lista, nos quais os eleitores podem votar apenas para partidos, não para candidatos individuais. Mas os partidos políticos enfraquecidos não empoderam "o povo"; eles empoderam os interesses organizados que são mais capazes de tirar proveito de um sistema de partidos políticos que não têm força organizacional suficiente para combater as forças privadas. Em pelo menos vinte e três estados, ignoramos completamente a política institucional formal através de práticas de democracia direta, tais como iniciativas de votação, referendos e ferramentas de recall que nenhuma outra democracia usa tanto, especialmente desde o ressurgimento da democracia direta na América que começou em 1978 com o símbolo da "revolta do imposto de propriedade", a Proposição 13 da Califórnia. ${ }^{22}$

Um dos melhores relatos comparativos da maneira como as características únicas da democracia americana se combinam para afetar tanto as eleições como a governança é tratado no livro de Anthony King, Running Scared: Why America's Politicians Campaign Too Much and Govern

especialmente nos 'tediosos períodos entre eleições', para desempenhar suas tarefas, como organizar colégios eleitorais, registrar novos eleitores e lhes prover serviços. Mesmo o maior dos entusiastas de um programa político retrocederá diante deste árduo trabalho e é loucura pensar que convicção ideológica, por si só, motivará números suficientes para manter o partido ao longo dos anos. Aqui está o julgamento de um desses políticos, Jacob Arvey (mais conhecido como o promoter de Adlai Stevenson): Patronato é um 'mal necessário se você quer uma forte organização, porque o patronato permite a disciplina e, sem disciplina, não há organização partidária.'" Rutan v. Republican Party of Illinois, 497 U.S. 62, 104 (1990), J. Scalia, dissentindo, citando Elrod v. Burns, 427 U.S. 347, 385 (1976), J. Powell, dissentindo; e TOLCHIN, Michael; TOLCHIN, Susan. To the Victor: Political Patronage from the Clubhouse to the White House. New York, NY: Random House, 1972, p. 36. ${ }^{22}$ Cf. ISSACHAROFF, Samuel; KARLAN, Pamela; PILDES, Richard. The Law of Democracy: Legal Structure of the Political Process. 4th ed. Westbury, NY: Foundation Press, 2012, p. 935-938 (dando uma revisão da democracia direta); PERSILY, Nathaniel. The Peculiar Geography of Direct Democracy: Why the Initiative, Referendum, and Recall Developed in the American West. Michigan Law \& Policy Review, Vol. 2, 1, 1997 (descrevendo a predominância das formas plebiscitárias da democracia norte-americana, utilizadas no oeste norte-americano). 
Too Little. ${ }^{23}$ Usando as experiências concretas de candidatos e autoridades específicos eleitas nos Estados Unidos, na Grã-Bretanha e no Canadá, King identifica várias características do processo democrático americano que tornam os políticos americanos "mais vulneráveis, mais vezes, às vicissitudes da política eleitoral do que os políticos de qualquer outro país democrático". ${ }^{24}$ As características únicas que se combinam para criar essa vulnerabilidade extrema são os mandatos extremamente curtos na Câmara; a utilização de eleições primárias na dependência das eleições gerais; a fraqueza dos partidos políticos americanos, que exige que os candidatos americanos sejam muito mais dependentes de sua própria capacidade de arrecadar dinheiro e divulgar sua mensagem; e os altos custos das campanhas nos Estados Unidos em comparação com os de vários outros países democráticos. ${ }^{25}$

$\mathrm{O}$ fato de que a democracia americana exibe essas estruturas e características únicas diante de tantas instituições diferentes em tantos domínios diferentes não é acidente. Subjacente às nossas instituições e práticas está uma cultura política democrática singular que sempre se baseou numa visão e compreensão ideias de "soberania popular" e "autogoverno". Na verdade, creio que a "soberania popular" é invocada muito mais comumente nos Estados Unidos do que em qualquer outro lugar. Simplificando, eu diria que a cultura democrática americana tem tido, há muito tempo, uma maneira particularmente individualista de "Direito" do autogoverno. Esta visão e o design de nossas instituições políticas têm sido constitutivos e reforçadores; como esta compreensão única da soberania popular tem levado as estruturas institucionais mais sujeitas a controle popular inusitadamente direto, a existência de longa data dessas instituições tem ajudado a enraizar e validar os entendimentos culturais. Vou me referir para a característica da cultura democrática americana incorporada nas ideias e instituições que eu tenho descrito como a "concepção individualista de governo democrático".

Mais especificamente, nossa cultura enfatiza de forma única - eu diria, romantiza - o papel e o suposto poder dos indivíduos e a "participação" direta na dinâmica e os processos de "autogoverno". Esta cultura muitas vezes prevê uma forma individualizada de ação política, na qual os principais elementos democráticos são cidadãos individuais, muitas

${ }^{23}$ Cf. KING, Anthony. Running Scared: Why America's Politicians Campaign too much and Govern too little. New York, NY: Martin Kessler Books, 1997.

${ }^{24}$ KING, Anthony. Running Scared: Why America's Politicians Campaign too much and Govern too little. New York, NY: Martin Kessler Books, 1997, p. 3. ${ }^{25}$ KING, Anthony. Running Scared: Why America's Politicians Campaign too much and Govern too little. New York, NY: Martin Kessler Books, 1997, p. 29-30. 
vezes retratados em esplêndido isolamento, e uma política democrática que surge através da geração espontânea. Essa visão obscurece as formas como a participação deve ser mobilizada, organizada e agregada para ser eficaz; pior ainda, a atração dessa visão muitas vezes levou os reformistas e acadêmicos a deixar de apreciar a maneira como as "reformas" são prováveis trabalhar na prática, uma vez que os atores mais organizados e mobilizados aproveitarão as vantagens que estas reformas abrem. Como parte desse quadro romântico da democracia, desconfiamos unicamente das instituições intermediárias organizadas que estão entre o cidadão e o governo, como os partidos políticos.

Podemos observar elementos dessa imagem idealizada desde os Federalists Papers. Apesar das convicções brilhantes e realistas dos Federalists Papers, esses documentos concebem eleições e governo essencialmente em uma espécie de vácuo político. Eles não dão conta do papel crítico dos atores políticos intermediários na mobilização e organização dos eleitores nas eleições (na verdade, eles conceberam eleições como casos de aclamação, e não competições políticas competitivas). Do mesmo modo, não fornecem uma descrição da necessidade de grupos intermediários organizados dentro do governo eleito para permitir a ação necessária para que o governo funcione efetivamente. ${ }^{26}$ Como outros pensadores políticos do século XVIII, os Framers desdenhavam os partidos políticos; recuou quando o governo dividiu-se logo em dois campos federais e republicanos distintos e guerreando; e encarava esta divisão como um mal temporário necessário, não como uma característica permanente e legítima da democracia. ${ }^{27}$

${ }^{26}$ Cf. ISSACHAROFF, Samuel; KARLAN, Pamela; PILDES, Richard. The Law of Democracy: Legal Structure of the Political Process. 4th ed. Westbury, NY:

Foundation Press, 2012, p. 7/215; e ROSENBLUM, Nancy. On the Side of the Angels: an Appreciation of Parties and Partisanship. Princeton, NJ: Princeton University Press, 2008, p. 89-92.

${ }_{27}$ Como Richard Hofstadter famosamente afirmou, a "ideia raiz" do pensamento político inglês e norte-americano, nesse período, era de que partidos políticos eram "malignos". Cf. HOFSTADTER, Richard. The Idea of a Party System: the Rise of Legitimate Opposition in the United States, 1780-1840. Berkeley, CA: University of California Press, 1970, p. 9. Cf., em geral, LEONARD, Gerald. The Invention of Party Politics: Federalism, Popular Sovereignty, and Constitutional Development in Jacksonian Illinois. Chapel Hill, NC: University of North Carolina Press, 2002 (escrevendo sobre o cenário político no final do Século XVIII). Para uma descrição mais sintética do papel central e poderoso do "antipartidarismo" no pensamento político 
A visão de mundo na época do enquadramento da Constituição abrangeu cidadãos, eleições e governo - mas não o conjunto dos partidos políticos, caucuses e organizações que são tão essenciais para organizar políticas, poder nas esferas das eleições e da governação. É claro que a visão de representação política do século XVIII era mais elitista do que a nossa, mas sua cegueira a todas as organizações intermediárias críticas entre cidadãos, eleições e governo refletem um modo de pensar caracteristicamente americano sobre a democracia. Podemos ver isso também na política externa americana, na visão ingênua de que as eleições imediatas conferirão legitimidade e democracia significativa a lugares emergentes de passados não democráticos, sem considerar se os vários fundamentos da democracia, como a pluralidade de grupos políticos organizados competindo pelo poder, ou uma imprensa robusta e independente, tiveram uma chance de se desenvolver.

A concepção individualizada de governo democrático moldou de maneira generalizada, e continua a moldar, a democracia americana. Vemos isso em design institucional, críticas comuns à democracia e esforços reformistas para "melhorar" a democracia americana. A concepção é amplamente aceita, e se reconhecida, é muito menos questionada. Desde a era Jacksoniana, o apelo a mais "empoderamento popular" ou participação como a cura para a corrupção tem sido um tema cultural e político constante na democracia americana ${ }^{28}$ - mesmo enquanto lutamos para corrigir as disfunções que reformas anteriores nesse sentido trouxeram..$^{29}$ Por exemplo, em 1974, quando o Congresso

ocidental, cf. ROSENBLUM, Nancy. On the Side of the Angels: an Appreciation of Parties and Partisanship. Princeton, NJ: Princeton University Press, 2008.

${ }^{28}$ Cf. WILENTZ, Sean. The Rise of American Democracy: Jefferson to Lincoln. New York, NY: Norton, 2005. Entre outras coisas, Wilentz detalha a prática que o Presidente Andrew Jackson celebrou como "rotação no cargo", que, quando acabou se tornando menos apelativa, passamos a chamar de patronato e foi um esforço reformista para expurgar o governo de um "estabelecimento político interno". WILENTZ, Sean. The Rise of American Democracy: Jefferson to Lincoln. New York, NY: Norton, 2005, p. 315-317. Cf., ainda, HOWE, Daniel Walker. What Hath God Wrought: the

Transformation of America, 1815-1848. New York, NY: Oxford University Press, 2007, p. 488-498 (discutindo votação durante a administração Jackson).

${ }^{29}$ Para uma visão similar, cf. KING, Anthony. Running Scared: Why America's

Politicians Campaign too much and Govern too little. New York, NY: Martin Kessler Books, 1997, p. 172: “O paradoxo que tem resultado é óbvio. Ele é facilmente declarado. A história recente sugere que, quando um grande número de norteamericanos se torna insatisfeito com os trabalhos de seu governo, eles reivindicam mais democracia. Quanto mais eles reivindicam mais democracia, mais disso eles 
derrubou o antigo sistema de comitês do Congresso para diluir o poder dos presidentes das comissões - na época, democratas do sul conservadores - o resultado foi a proliferação de comitês e subcomitês. No entanto, alguns argumentaram que, minando o poder dos presidentes das comissões e difundindo o poder no Congresso de forma mais "democrática", o resultado seria o aumento o poder dos grupos de interesse privado para bloquear a legislação, expandindo ainda mais o número de vetos no sentido, diluindo, dessa forma, o poder político. ${ }^{30}$

Na verdade, o impulso central por trás de muitos de nossos esforços de reforma democrática não é criticar ou desafiar a concepção individualista da democracia, mas sim insistir em mais "participação" e outras formas de "empoderar" os cidadãos individuais como uma solução para nossos desafios democráticos. Exigimos que muitas de nossas instituições sejam escolhidas através de eleições, na visão de que, por exemplo, o controle "cidadão" manterá os funcionários mais próximos do bem comum, sem qualquer avaliação realista de como o processo eleitoral realmente funciona; com visões românticas sobre o quanto de interesse a maioria dos cidadãos terá (ou melhor, não terá) em participar dos processos de votação de instituições de nível inferior; e sem considerar a possibilidade de que os interesses privados organizados poderão dominar eleições de baixa participação. Essa abordagem é antiga. Por exemplo, não só escolhemos comissões escolares em muitas partes dos Estados Unidos, mas as políticas da Era Progressista pediram que estas (e outras) eleições locais fossem realizadas num calendário separado das eleições gerais, de modo que a tomada de decisão local seria "mais pura" e não englobada em questões políticas mais amplas. ${ }^{31}$ No entanto, se o comparecimento às eleições da diretoria escolar é extremamente baixo, é ainda menor quando essas eleições são realizadas fora do ciclo; não surpreendentemente, o único interesse que está sempre

conseguem. E, quanto mais eles conseguem disso, mais insatisfeitos ficam com os trabalhos de seu governo. E, quanto mais eles ficam insatisfeitos com os trabalhos do governo, mais eles reivindicam por democracia. E, quanto mais eles reivindicam mais democracia, mais disso eles ganham. E, quanto mais eles ganham disso, mais insatisfeitos ficam... e assim segue o ciclo infindavelmente se repetindo."

${ }^{30}$ Cf. FRUM, David. The Transparency Trap: Why Trying to Make Government More Accountable Has Backfired. The Atlantic, Aug. 13, 2014. Disponível em: $<$ http://www.theatlantic.com/magazine/archive/2014/09/the-transparencytrap/375074>. Acesso em: 14 de Agosto de 2017.

${ }^{31}$ ANZIA, Sarah. Timing \& Turnout: How Off-Cycle Elections Favor Organized Groups. Chicago, IL: University of Chicago Press, 2014, p. 167. 
bem representado nas eleições do conselho escolar, não importa quando são realizadas, é o dos professores, que têm a participação mais direta nas políticas do conselho escolar. Talvez também não surpreendentemente, $\mathrm{o}$ trabalho empírico recente "é notavelmente claro" ao demonstrar que quanto menor a participação em tais eleições, maior influência eleitoral e política os professores tem - e, como resultado, os salários dos professores tornam-se maiores..$^{32}$ Nossa cultura parece sofrer de uma disfunção democrática, e para uns a solução é um maior "empoderamento" do cidadão, para outros, devemos enfrentar as consequências ruins dessa solução prévia, apenas para tentar outra maneira de garantir mais transparência e controle cidadão.

Quero rechaçar um pouco essa cultura e essa visão romântica do autogoverno individual que a sustenta.

\section{As CAUSAS DA POLARIZAÇÃo}

Para começar a fazer isso, passarei agora à minha análise das razões pelas quais nossas instituições políticas se tornaram tão paralisadas nos últimos anos.

É sabido que nossa era de governança é constituída pelo que eu chamei de "partidos políticos hiperpolarizados". ${ }^{33}$ Por todas as medidas convencionais, os partidos no governo estão mais polarizados do que em qualquer outro momento desde o final do século XIX. ${ }^{34}$ Tenha em mente que a polarização partidária não é necessariamente ruim, ou de todo ruim, de uma perspectiva democrática mais ampla. A polarização

32 ANZIA, Sarah. Timing \& Turnout: How Off-Cycle Elections Favor Organized Groups. Chicago, IL: University of Chicago Press, 2014, p. 166.

${ }^{33}$ Cf. PILDES, Richard. Why the Center Does Not Hold: The Causes of Hyperpolarized Democracy in America. California Law Review, Vol. 99, 2, 2011.

${ }^{34}$ Cf. McCARTY, Nolan, et. al.. Polarized America: the Dance of Ideology and Unequal Riches. Cambridge, MA: The MIT Press, 2006, p. 15-70; ROHDE, David. Parties and Leaders in the Postreform House. Chicago, IL: University of Chicago Press, 1991, p. 13-16; SINCLAIR, Barbara. Party Wars: Polarization and the Politics of National Policy Making. Norman, OK: University of Oklahoma Press, 2006, p. 3-35; STONECASH, Jeffrey, et. al.. Diverging Parties: Social Change, Realignment, and Party Polarization. Boulder, CO: Westview Press, 2003, p. 18; BARBER, Michael; McCARTY, Nolan. Causes and Consequences of Polarization. In: Jane Mansbridge; Cathie Jo Martin (eds.). Negotiating Agreement in Politics. Washington, DC: American Political Science Association, 2013, p. 19-20. 
política, do meu ponto de vista, é uma preocupação primordial na medida em que afeta a capacidade de governança. Outros podem se incomodar com uma cultura política caracterizada por divisão, falta de discordância civil, etc., mas minha preocupação dominante são as consequências da polarização para uma governança efetiva. De fato, a polarização pode muito bem envolver conflitos trágicos entre os domínios do voto e da governança, um conflito muito mais geral na prática democrática do que a teoria democrática reconheceu. Como os defensores dos partidos políticos há muito tempo argumentam, os partidos políticos coerentes e fortemente diferenciados aumentam a participação dos eleitores, tornando o voto mais significativo - a legenda do partido político é mais representativa - e permitem, dessa forma, que os eleitores responsabilizem mais significativamente aqueles que foram eleitos. ${ }^{35}$ Como resultado, a polarização partidária tem benefícios eleitorais distintos; não é uma questão que só traz custos e nenhum benefício. Portanto, devemos considerar a polarização partidária como um problema significativo apenas se e quando seus custos forem suficientemente substanciais para superar esses benefícios eleitorais. Evitar que o governo tome medidas eficazes, mesmo quando exista um amplo acordo quanto ao fato de que o governo deve agir de alguma forma, sinaliza que os custos da polarização superam seus benefícios substancialmente suficientes para justificar a busca de medidas que possam atenuar esses custos, incluindo medidas de design institucional.

Para entender quais as medidas que poderiam ser mais eficazes - e para justificar o meu argumento de que a nossa busca deve mover-se em uma direção diferente do que a que é tipicamente sugerida por aqueles preocupados com a extrema polarização partidária - eu preciso começar explicando as causas e sugerir "curas" para o nosso mundo de partidos políticos hiperpolarizados. $O$ que causou a dramática polarização partidária de nossa era? A polarização não é, em minha opinião, produto de forças recentes ou relativamente contingentes ou de personalidades individuais.

Argumentamos que a hiperpolarização dos tempos de hoje é esmagadoramente um produto de forças históricas e estruturais de longo

${ }^{35}$ Cf. RANNEY, Austin. The Doctrine of Responsible Party Government: Its Origins and Present State. Urbana, IL: University of Illinois Press, 1954. Cf., em geral, GARRETT, Elizabeth. Voting with Cues. University of Richmond Law Review, Vol. 37, 4, 2003 (descrevendo como eleitores colhem significados de rótulos de partidos políticos e outros sinais). 
prazo. ${ }^{36}$ Essas forças foram lançadas em movimento com a Era dos Direitos Civis dos anos 1960, particularmente com a Voting Rights Act, como afroamericanos (e muitos brancos pobres) iniciaram o processo de ter acesso ao sufrágio universal. ${ }^{37}$ É fácil esquecer que, desde a década de 1890 até a Era dos Direitos Civis, todo o Sul dos Estados Unidos era um monopólio de partido único, criado artificialmente, pelo Partido Democrático. ${ }^{38} \mathrm{O}$ processo de acabar com esse monopólio político artificial começou em 1965, mas os efeitos totais dessa mudança não ocorreram de um dia para o outro; foram várias décadas de processos dinâmicos e de esforço para que Partido Democrata no Sul se movesse em direção à esquerda política, para que crescesse um Partido Republicano forte e competitivo, e para que os brancos conservadores mudassem preferência partidária para o Partido Republicano para as eleições do Senado, para a Câmara e para eleições locais. ${ }^{39}$

Somente nos anos 1990, notavelmente, vemos o tipo de sistema político bipartidário no Sul que o resto do país teve ao longo do século XX. ${ }^{40}$ Em minha opinião, o regime de redistribuição racial da Voting Rights Act contribuiu para este processo. A Voting Rights Act se firmou pela primeira vez na redistribuição de distritos dos anos 1990, como resultado das emendas de 1982 à Seção 2 da Voting Rights Act e, talvez mais importante ainda, da decisão de Thornburg v. Gingles, de 1986, da Suprema Corte. ${ }^{41}$ A redistribuição de distritos pós-1990 mudou a representação política do Partido Democrata no Sul em direção à sua ala mais liberal, reduzindo drasticamente o número de democratas brancos moderados no sul, e facilitou o surgimento de muitos distritos mais

${ }^{36}$ Cf. PILDES, Richard. Why the Center Does Not Hold: The Causes of Hyperpolarized Democracy in America. California Law Review, Vol. 99, 2, 2011, p. 287-297.

37 PILDES, Richard. Why the Center Does Not Hold: The Causes of Hyperpolarized Democracy in America. California Law Review, Vol. 99, 2, 2011, p. 287-288.

38 PILDES, Richard. Why the Center Does Not Hold: The Causes of Hyperpolarized Democracy in America. California Law Review, Vol. 99, 2, 2011, p. 297.

${ }^{39}$ Cf. PILDES, Richard. Democracy, Anti-Democracy and the Canon. Constitutional Commentary, Vol. 17, 2, 2000, p. 295/301-304; e PILDES, Richard. Why the Center Does Not Hold: The Causes of Hyperpolarized Democracy in America. California Law Review, Vol. 99, 2, 2011, p. 288/292-293.

${ }^{40}$ Cf. BLACK, Earl; BLACK, Merle. The Rise of Southern Republicans. Cambridge, MA: Harvard University Press, 2002 (representando a falta de Republicanos no Sul até o Século XX).

${ }^{41}$ Cf. 42 U.S.C. $\$ 1973$ (2012); e Thornburg v. Gingles, 478 U.S. 30 (1986) (sustentando que um plano de reorganização de distritos resultando em diluição de eleitores negros violava a Seção 2 da Voting Rights Act). 
conservadores e republicanos. ${ }^{42}$

Através deste conjunto revolucionário de mudanças históricas, as duas partes políticas, tanto a nível nacional como estadual, tornaram-se "purificadas" em entidades muito mais ideologicamente coerentes. Os eleitores agora se encaixam nos dois partidos de maneira geral e correta, por ideologia, de modo que quase todos os liberais são agora democratas, e todos os conservadores agora são republicanos ${ }^{43}$ Isso simplesmente não aconteceu durante a maior parte do século passado.

Se você aceitar minha opinião sobre isso, então se segue que a estrutura partidária altamente polarizada de nossa política democrática não deve ser vista como uma aberração. Deve ser entendido como o "novo normal". Em vez de ser o produto de características contingentes de nossas instituições atuais ou de nosso momento político presente, é o resultado de processos históricos profundos e de longo prazo. Em outras palavras, a polarização deve ser aceita como um fato suscetível de persistir por algum tempo, não algo que possamos projetar.

No entanto, grande parte da energia intelectual e reformista tem sido gasta na busca de soluções reformistas para uma extrema polarização partidária. Essa energia tem sido direcionada para restaurar o "centro de desaparecimento" na democracia americana. ${ }^{44}$ Tendo em vista os remédios recomendados para a polarização que descrevo a seguir, tornase necessário explorar brevemente por que certas soluções para a

42 Em 1991, o último ano antes da reorganização dos distritos, a delegação parlamentar do Sul consistia em setenta e dois Democratas brancos, cinco Democratas negros e trinta e nove Republicanos brancos; uma década após, sob os distritos criados em 1992, havia trinta e sete Democratas brancos, dezesseis Democratas negros e setenta e um Republicanos brancos (e um independente). Cf. BLACK, Earl; BLACK, Merle. The Rise of Southern Republicans. Cambridge, MA: Harvard University Press, 2002, p. 13; Cf., ainda, PILDES, Richard. The Politics of Race. Harvard Law Review, Vol. 108, 6, 1995, p. 1364-1365 (descrevendo as mudanças ocorridas após a reorganização dos distritos). Obviamente, havia significativas mudanças seculares que eram o mais importante conjunto de forças dividindo a ascensão do Republicanismo no Sul, mas a mudança extrema, e quase da noite para o dia, poucos ano após a reorganização dos distritos, na década de 1990, acelerou essas forças seculares.

${ }^{43}$ LEVENDUSKY, Matthew. The Partisan Sort: How Liberals became Democrats and Conservatives became Republicans. Chicago, IL: Chicago University Press, 2009, p. 38-77.

${ }^{44}$ Cf., por exemplo, ABRAMOWITZ, Alan. The Disappearing Center: Engaged Citizens, Polarization, and American Democracy. New Haven, CT: Yale University Press, 2010, p. 139-157. 
polarização provavelmente não serão úteis e, por que tais "correções" podem até ser perversas, se o objetivo é permitir um conjunto mais efetivo de instituições políticas capazes de superar a paralisia atual.

As "correções" para a polarização podem ser categorizadas em duas formas. A primeira envolve mudanças nas estruturas institucionais das eleições, que mudarão o rol de candidatos e governadores para representar uma massa crítica de funcionários mais centristas capazes de superar divisões partidárias. Estas propostas de design institucional incluem aquelas que foram oferecidas - primárias abertas; comissões independentes para realizar a redistribuição de distritos, talvez com instruções para maximizar a concorrência; mudanças nas regras legislativas internas - e as menos conhecidas: eliminação de leis que proíbem candidaturas de "maus-perdedores" 45; mudança para a votação instantânea; ou mesmo, mais radicalmente, abolindo totalmente as primárias e retornando a um sistema de seleção de candidatos pelos líderes partidários.

Do ponto de vista institucional, as duas correções que receberam maior atenção estão acabando com a germinação e abertura das eleições primárias a um eleitorado mais amplo do que apenas os membros do partido. Essas mudanças podem ser desejáveis por muitas razões, mas ao determinar se as mudanças de projeto institucional nessas áreas são suscetíveis de fazer uma contribuição significativa para reduzir a polarização partidária, não devemos ser muito otimistas sobre esta perspectiva à medida que mais evidências empíricas crescem. ${ }^{46}$ Continuo

${ }^{45}$ Para uma crítica das proibições a candidaturas de maus-perdedores, cf. KANG, Michael. Sore Loser Laws and Democratic Contestation. Georgetown Law Review, Vol. 99, 4, 2011.

${ }^{46}$ Sobre gerrymandering, grande parte da discussão tende a confundir a questão do aumento de "cadeiras seguras" para um partido ou outro, o que tem ocorrido, com gerrymandering enquanto a causa desse aumento das cadeiras seguras. Muitos estudos empíricos concluem, agora, que o aumento da concentração geográfica de Democratas em zonas urbanas, e seus isolamentos geográficos em cidades universitárias e outras áreas, são as principais causas para tal aumento das cadeiras seguras. Cf., por exemplo, McCARTY, Nolan, et. al.. Polarized America: the Dance of Ideology and Unequal Riches. Cambridge, MA: The MIT Press, 2006; McCARTY, Nolan, et. al.. Does Gerrymandering Cause Polarization? American Journal of Political Science, Vol. 53, 3, 2009; CHEN, Jowei; RODDEN, Jonathan. Don't Blame the Maps. The New York Times, Jan. 24, 2014. Disponível em: <http://www.nytimes.com/2014/01/26/opinion/sunday/its-the-geography-stupid.htmll>. Acesso em: 14 de agosto de 2017. O estudo mais abrangente, até então, que foca apenas eleições para legislaturas estaduais, não analisando o Congresso, examina tanto os 
a ser mais otimista de que mudanças na estrutura das eleições primárias poderiam fazer a diferença, mas há pouca evidência empírica sistemática para apoiar essa esperança. ${ }^{47}$

A segunda categoria de reformas, sobre a qual eu gostaria de focar mais, visa reduzir a polarização no governo, capacitando o "povo" de forma mais eficaz. A ideia é que maior participação do cidadão será uma solução para a disfunção política e a polarização. Esta ideia é baseada no pressuposto de que a polarização partidária não está em nós, mas em nossos partidos políticos; a polarização em nossa política é uma corrupção ou distorção da política mais moderada e centrista que teríamos se pudéssemos encontrar formas de dar ao povo mais controle direto ou influência sobre eleições e governança. A ideia é parte de um desejo ou visão recorrente em toda a história política americana. Mas há boas razões para desconfiar dessa ideia e até pensar que os esforços institucionais para refletir o empoderamento popular tornariam a polarização pior, não melhor.

Enquanto trabalhos acadêmicos anteriores sugeriam que "o público"

efeitos dentro dos Estados que mudam seu sistema primário, quanto o comportamento de legisladores estaduais selecionados por diferentes estruturas de eleições primárias. O estudo revela não haver impacto provocado por diferentes estruturas de eleições primárias sobre o partidarismo daqueles eleitos. Cf. McGHEE, Eric, et. al.. A Primary Cause of Partisanship? Nomination Systems and Legislator Ideology. American Journal of Political Science, Vol. 58, 2, 2014.

${ }^{47}$ Temos apenas evidências anedóticas, neste estágio, de formas mais recentes de primárias, como as primárias dos "dois melhores", recentemente usadas na Califórnia e em Washington, e a análise dos dados tendem a estar em tensão entre si até agora. Compare KOUSSER, Thad, et. al.. Reform and Representation: Assessing California's Top-Two Primary and Redistricting Commission. Working Paper, 2013. Disponível em:

$<$ http://www.columbia.edu/ jhp2121/workingpapers/ReformAndRepresentation.pdf $>$. Acesso em: 14 de Agosto de 2017 (concluindo que, para a delegação parlamentar da Califórnia, o hiato entre as ideologias do eleitor e do legislador, efetivamente, expandiu de 2010 para 2012, após a Califórnia ter adotado as primárias dos “dois melhores" e reorganizado os distritos); com GROSE, Christian. The Adoption of Electoral Reforms and Ideological Change in the California State Legislature. Los Angeles, CA: Schwarzenegger Institute of University of Southern California, 2014. Disponível em: $<$ http://www.schwarzeneggerinstitute.com/images/SIAdoption\%20of\%20Electoral\%20Reforms\%20Report.pdf >. Acesso em: 14 de agosto de 2017 (concluindo que a legislatura da Califórnia se tornou mais moderada e menos polarizada após estas reformas surtirem efeito). 
era mais centrista do que aqueles que ocupavam cargos públicos, trabalhos mais recentes revelam que a polarização no governo não é tão obviamente uma distorção ou corrupção das visões menos polarizadas do público maior. Alan Abramowitz mostrou que os "cidadãos politicamente engajados" são tão polarizados quanto os partidos no governo. ${ }^{48}$ Ser "engajado" nesse sentido significa pouco mais do que participar das formas mais básicas de participação democrática, tais como: votação; tentando persuadir um amigo ou vizinho a votar; exibindo um adesivo de para-choque ou placa de rua; dar dinheiro; ou participar de uma reunião de campanha. As descobertas de Abramowitz, portanto, colocam um sério desafio à ideia de que mais participação se traduzirá em menos polarização. ${ }^{49}$

Shanto Iyengar e seus coautores descobriram que os partidários estão hoje muito mais desconfortáveis do que no passado com seus filhos se casando com aqueles que se identificam com outros partidos. ${ }^{50} \mathrm{E}$, embora os cidadãos em geral não sejam tão ideologicamente extremos quanto partidários, estamos altamente divididos em termos partidários atualmente; $92 \%$ dos republicanos são mais conservadores do que o democrata médio, enquanto $94 \%$ dos democratas são mais liberais do que o republicano médio (vinte anos atrás, os números eram $64 \%$ e $70 \%$, respectivamente). ${ }^{51}$

48 ABRAMOWITZ, Alan. The Disappearing Center: Engaged Citizens, Polarization, and American Democracy. New Haven, CT: Yale University Press, 2010.

${ }^{49}$ As descobertas de Abramowitz sobre cidadãos politicamente engajados foram, recentemente, replicadas no maior estudo do Pew Research Center, que concluiu que "com medidas sobre medidas - sejam votações primárias, redação de cartas a agentes, participação voluntária ou doação para campanha - os mais politicamente polarizados são mais envolvidos ativamente na política, amplificando as vozes que são as menos dispostas a ver os partidos se encontrando pelo caminho" PEW RESEARCH CENTER. Political Polarization in the American Public: How Increasing Ideological Uniformity and Partisan Antipathy Affects Politics, Compromise, and Everyday Life. 2014. Disponível em: <http://www.people-press.org/2014/06/12/politicalpolarization-in-the-american-public $>$. Acesso em: 14 de agosto de 2017.

${ }^{50}$ Cf. IYENGAR, Shanto, et. al.. Affect, Not Ideology: A Social Identity Perspective on Polarization. Public Opinion Quarterly, Vol. 76, 3, 2012, p. 415-418 (concluindo que dados demonstram "que, tanto Republicanos, quanto Democratas, desgostam cada vez mais de seus oponentes").

${ }^{51}$ Cf. PEW RESEARCH CENTER. Political Polarization in the American Public: How Increasing Ideological Uniformity and Partisan Antipathy Affects Politics, Compromise, and Everyday Life. 2014. Disponível em: $<$ http://www.peoplepress.org/2014/06/12/political-polarization-in-the-american-public $>$. Acesso em: 14 de 
A porcentagem dos que são consistentemente liberais ou conservadores, em vez de ter uma mistura de tais pontos de vista, dobrou de $10 \%$ para $21 \%$ nas últimas duas décadas. ${ }^{52}$ Como Marc Hetherington e outros relatam, aqueles que se identificam com um partido expressam muito mais sentimentos negativos sobre o outro partido do que no passado. ${ }^{53}$ Um importante estudo recente do Pew Research Center conclui que, em 1994, apenas 17\% dos republicanos e 16\% dos democratas tinham uma visão "muito avessa" sobre as visões do partido oposto, enquanto atualmente $43 \%$ dos Republicanos e 38\% dos Democratas tem essa aversão às visões do outro. ${ }^{54}$ Outros cientistas sociais sugerem que o público é ainda mais extremo em seus pontos de vista políticos do que os políticos ou, pelo menos, do que aqueles cujas opiniões são categorizadas

agosto de 2017. Sobre a diferença entre extremismo político e classificação política ao longo das linhas partidárias, cf. FIORIAN, Morris. Americans Have Not Become More Polarized. The Washington Post, Jun. 23, 2014. Disponível em:

$<$ http://www.washingtonpost.com/blogs/monkey-cage/wp/2014/06/23/americans-havenot-become-more-politically-polarized $>$. Acesso em: 14 de agosto de 2017 (criticando o relatório do Pew Research Center, como se tivesse descaracterizado seus resultados). 52 PEW RESEARCH CENTER. Political Polarization in the American Public: How Increasing Ideological Uniformity and Partisan Antipathy Affects Politics, Compromise, and Everyday Life. 2014. Disponível em: $<$ http://www.peoplepress.org/2014/06/12/political-polarization-in-the-american-public $>$. Acesso em: $14 \mathrm{de}$ agosto de 2017.

${ }^{53}$ HETHERINGTON, Marc; RUDOLPH, Thomas. Why Don't Americans Trust the Government? Because the Other Party Is in Power. The Washington Post, Jan. 30, 2014. Disponível em: $<$ https://www.washingtonpost.com/news/monkeycage/wp/2014/01/30/why-dont-americans-trust-the-government-because-the-otherparty-is-in-power/?utm term=.fff2eee3a2d9>. Acesso em: 14 de agosto de 2017; cf., ainda, HAIDT, Jonathan; HETHERINGTON, Marc. Look How Far We've Come Apart. The New York Times, Sept. 17, 2012. Disponível em: $<$ http://campaignstops.blogs.nytimes.com/2012/09/17/look-how-far-weve-come-apart $>$. Acesso em: 14 de agosto de 2017.

${ }^{54}$ PEW RESEARCH CENTER. Political Polarization in the American Public: How Increasing Ideological Uniformity and Partisan Antipathy Affects Politics, Compromise, and Everyday Life. 2014. Disponível em: $<$ http://www.peoplepress.org/2014/06/12/political-polarization-in-the-american-public >. Acesso em: $14 \mathrm{de}$ agosto de 2017. 
como "moderadas" são, de fato, ideologicamente polarizadas demais. ${ }^{55}$ Além disso, cidadãos, ativistas e dirigentes eleitos agora veem mais problemas em termos unidimensionais e partidários. Como Carsey e Layman afirmam: "Os dados são claros: em todas as três principais áreas de interesse doméstico - bem-estar social, raça e cultura - tem havido um aumento constante na distância entre cidadãos democratas $\mathrm{e}$ republicanos, Ativistas". ${ }^{56} \mathrm{Na}$ política estadual, vemos um padrão semelhante ao do Congresso. Em média, as legislaturas estaduais estão se tornando significativamente mais polarizadas. ${ }^{57}$

Se o envolvimento político correlaciona-se com o aumento da polarização, de acordo com a pesquisa de Abramowitz, então devemos ser céticos de que encontrar maneiras de aumentar a participação popular irá reduzir a polarização. Além disso, a participação não brota espontaneamente, como cogumelos depois de uma chuva. A participação tem que ser energizada, organizada, mobilizada e canalizada em direções efetivas - tudo o que requerem as próprias organizações e os partidários, e que a participação "cidadã" está destinada a contornar. Além disso, o envolvimento político pode não apenas envolver indivíduos que se auto selecionam para o partidarismo, mas também pode ser uma experiência que gera polarização. Além disso, apesar de todo o cinismo sobre a política de hoje, "os americanos [agora] estão mais interessados na política, mais bem informados sobre os assuntos públicos e mais politicamente ativos do que em qualquer outro momento do último meio século". ${ }^{58} \mathrm{~A}$ cada vez mais nós estamos envolvidos nas formas idealizadas que cidadãos democráticos são pensados para ser. E nós somos partidários. Causa e efeito são difíceis de separar aqui. Mas você conhece

${ }_{55}$ Cf., por exemplo, BROOCKMAN, David. An Artificial “Disconnect"? Assuming Americans Are Reliably Ideological Masks Public Support for Policies More Extreme than Politicians Pursue. Manuscrito não publicado, 2014 (arquivado com o autor). ${ }^{56}$ CARSEY, Thomas; LAYMAN, Geoffrey. Our Politics Is Polarized on More Issues than Ever Before. The Washington Post, Jan. 17, 2014. Disponível em: $<$ http://www.washingtonpost.com/blogs/monkey-cage/wp/2014/01/17/our-politics-ispolarized-on-more-issues-than-ever-before >. Acesso em: 14 de agosto de 2017. ${ }^{57}$ Cf., por exemplo, SHOR, Boris; McCARTY, Nolan. The Ideological Mapping of American Legislatures. American Political Science Review, Vol. 105, 3, 2011, p. 546547; e McCARTY, Nolan, et. al. Geography and Polarization. 2013, p. 2. Disponível em: <http://www.stanford.edu/ jrodden/wp/geo polar apsa2013 V4.pdf $>$. Acesso em: 14 de agosto de 2017 (descobrindo, em parte, que muitos dos distritos aparentemente moderados são, na verdade, internamente polarizados). ${ }^{58}$ ABRAMOWITZ, Alan. The Disappearing Center: Engaged Citizens, Polarization, and American Democracy. New Haven, CT: Yale University Press, 2010, p. 19. 
muitas pessoas politicamente engajadas que não são partidárias, fora de grupos como a League of Women Voters, cuja adesão caiu quase pela metade desde 1969, de acordo com Putnam $?^{59} \mathrm{O}$ extremismo em nome da moderação não é um vício, mas também não levanta um monte de dinheiro ou angaria um monte de voluntários. Devemos ser cautelosos em romantizar um público mais engajado como um veículo que nos salvará do governo partidário hiperpolarizado.

Apelar por mais "participação" como uma cura para a polarização reduz-se, portanto, a uma espécie estranha de esperança de que, quando os não engajados políticos se engajarem, eles não se comportarão como aqueles que já são engajados politicamente. Eles passarão intocados pelo mecanismo da democracia, mas permanecerão os mesmos inocentes e politicamente desinformados como quando começaram. Mas a sua participação terá de ser mobilizada, organizada, dirigida e pelo menos modestamente informada. Isso não os fará agir da mesma maneira que os cidadãos que já estão envolvidos?

Permitam-me que torne esse ponto concreto direcionando-o para a questão específica e crucial do financiamento de campanha. Eu mostrarei como certas propostas que focalizam em encorajar mais participação dos cidadãos são prováveis ter a consequências indesejadas e obstruir a governança eficaz.

Vou declarar a minha preferência desde o início: prefiro um sistema de financiamento público, mas não o tipo de financiamento público centrado em candidatos individuais que existe nos Estados Unidos (nos poucos lugares onde o temos).$^{60}$ Sugerem um sistema de financiamento público no qual mais ênfase e mais fluxo de dinheiro se orientam para os partidos políticos do que para os candidatos individuais. Voltarei brevemente a esta proposta.

Contudo, a fim de manter o tema do "empoderamento" de uma maior participação cidadã, alguns defensores do financiamento público sugeriram que o financiamento de campanhas não é feito pelo Estado, como no financiamento público em todo o mundo, mas sim através de

${ }^{99}$ PUTNAM, Robert. Bowling Alone: America's Declining Social Capital. Journal of Democracy, Vol. 6, 1, 1995, p. 69.

${ }^{60} \mathrm{Cf}$. NATIONAL CONFERENCE OF STATE LEGISLATURES. Overview of State

Laws on Public Financing. 2013. Disponível em:

$<$ http://www.ncsl.org/research/elections-and-campaigns/public-financing-ofcampaigns-overview.aspx>. Acesso em: 14 de agosto de 2017. 
vouchers individuais fornecidos a todos nós. ${ }^{61}$ Uma proposta distintamente americana, pois reflete, creio eu, a peculiar e radicalmente individualista cultura da democracia americana, juntamente com nossa desconfiança característica de formas mais organizadas de poder político.

Contudo, verifica-se que os doadores individuais são mais ideologicamente extremos e mais polarizados do que os não doadores como acabamos de discutir, os politicamente engajados estão mais polarizados do que o público em geral. ${ }^{62} \mathrm{Na}$ verdade, os doadores são mais ideológicos do que os doadores "partidários ativos", definidos como aqueles que se identificam com um partido político e se envolvem em

${ }^{61}$ A primeira proposta de esquema de voucher para financiamento de campanhas de que tive conhecimento na literatura jurídica é HASEN, Richard. Clipping Coupons for Democracy? An Egalitarian/Public Choice Defense of Campaign Finance Vouchers. California Law Review, Vol. 84, 1, 1996, p. 5. Esquemas de voucher também são endossados em ACKERMAN, Bruce; AYRES, Ian. Voting with Dollars: a New Paradigm for Campaign Finance. New Haven, CT: Yale University Press, 2002, p. 181221; e LESSIG, Lawrence. A Reply to Professor Hasen. Harvard Law Review, Vol. 126, 2, 2013, p. 66.

${ }^{62}$ Essa descoberta tem sido documentada em diversos estudos. Cf., por exemplo, FRANCIA, Peter, et. al.. The Financiers of Congressional Elections: Investors, Ideologues, and Intimates. New York, NY: Columbia University Press, 2003; BARBER, Michael; McCARTY, Nolan. Causes and Consequences of Polarization. In: Jane Mansbridge; Cathie Jo Martin (eds.). Negotiating Agreement in Politics. Washington, DC: American Political Science Association, 2013, p. 15-17 (mostrando que doadores são mais extremos do que não-doadores em cada levantamento anual), p. 15-17 (mostrando que doadores permanecem mais ideológicos, mesmo após controles serem adicionados para formas não-monetárias de participação); BAFUMI, Joseph; HERRON, Michael. Leapfrog Representation and Extremism: A Study of American Voters and Their Members in Congress. American Political Science Review, Vol. 104, 3, 2010; BARBER, Michael. Ideological Donors, Contribution Limits, and the Polarization of State Legislatures. Working Paper. 2013. Disponível em: $<$ http://citeseerx.ist.psu.edu/viewdoc/download?doi=10.1.1.668.8067\&rep=rep1\&type= pdf $>$. Acesso em: 14 de agosto de 2017. Tanto pequenos doadores (abaixo de 200 dólares), quanto grandes (acima de 200 dólares), têm muito mais preferências políticas bimodais - ambos estão na direita ou na esquerda, e não no centro - comparados com não-doadores. Cf. LA RAJA, Raymond; SCHAFFNER, Brian. Want to Reduce Polarization? Give Parties More Money. The Washington Post, Jul. 21, 2014. Disponível em: $<$ http://www .washingtonpost.com/blogs/monkeycage/wp/2014/07/21/want-to-reduce-polarization-give-parties-more-money $>$. Acesso em: 14 de agosto de 2017. 
atividades mais políticas do que o mero ato de votar. ${ }^{63}$ Além disso, os doadores de campanhas individuais também são ideologicamente mais extremos do que a maioria dos outros doadores, como os PACs e os partidos políticos. ${ }^{64}$ Os PACs tendem a se concentrar nos candidatos moderados, e nos situacionistas; os doadores individuais se concentram em candidatos ideologicamente mais polarizados. Em geral, os grupos que doam tendem a financiar moderados e os situacionistas, enquanto os doadores ideológicos favorecem desafiadores e os candidatos mais extremos. ${ }^{65}$ Em outras palavras, o dinheiro ideologicamente mais extremo para as campanhas vem de doadores individuais. Além disso, trabalhos recentes concluem que os padrões de votação dos senadores acompanham mais de perto as preferências políticas de seus doadores individuais, e não os dos eleitores no estado ou até mesmo os copartidários do Estado - e isso empurra os senadores para os polos ideológicos. ${ }^{66}$ Os senadores democratas são mais liberais, os republicanos mais conservadores do que os seus eleitores, mas esses políticos refletem

${ }^{63}$ BARBER, Michael. Ideological Donors, Contribution Limits, and the Polarization of State Legislatures. Working Paper. 2013, p. 12-13. Disponível em:

$<$ http://citeseerx.ist.psu.edu/viewdoc/download?doi=10.1.1.668.8067\&rep=rep1\&type= pdf $>$. Acesso em: 14 de agosto de 2017. Para um resumo dos estudos mostrando que doadores individuais vêm dos polos ideológicos da distribuição preferências gerais por políticas públicas, cf. STEPHANOPOULOS, Nicholas. Aligning Campaign Finance Law. Virginia law Review, Vol. 101, 5, 2015.

${ }^{64}$ STEPHANOPOULOS, Nicholas. Aligning Campaign Finance Law. Virginia law Review, Vol. 101, 5, 2015. Para uma visão dissidente, cf. MALBIN, Michael. Small Donors: Incentives, Economies of Scale, and Effects. Forum, Vol. 11, 3, 2013, p. 397, apontando que, entre incumbentes, os maiores $5 \%$ dos pequenos doadores foram distribuídos aleatoriamente em termos ideológicos dentro dos partidos.

${ }_{65}$ BONICA, Adam. Ideology and Interests in the Political Marketplace. American Journal of Political Science, Vol. 57, 2, 2013. Sobre a diferença entre as estratégias de grupos de interesse para financiamento de campanhas que são baseadas em acesso e aquelas buscando substituir candidatos pelos mais preferidos, cf. ISSACHAROFF, Samuel; PETERMAN, Jeremy. Special Interests After Citizens United: Access, Replacement, and Interest Group Response to Legal Change. Annual Review of Law and Social Science, Vol. 9, 1, 2013.

${ }^{66}$ BARBER, Michael. Representing the Preferences of Voters, Partisans, and Donors in the U.S. Senate. Working Paper. 2014, p. 18. Disponível em:

$<$ http://citeseerx.ist.psu.edu/viewdoc/download?doi=10.1.1.668.1643\&rep=rep1\&type= pdf $>$. Acesso em: 14 de agosto de 2017. Este estudo examina senadores incumbentes para reeleições em 2012 e "senadores", neste texto, refere-se a esse grupo. 
o ponto de vista de suas doações individuais.

Além disso, as campanhas dos candidatos tornaram-se dramaticamente mais dependentes dos doadores individuais nas últimas décadas do que em todas as outras fontes combinadas, como os partidos políticos e os PACs, mesmo quando nossos candidatos e partidos se tornaram cada vez mais polarizados. Em outras palavras, à medida que nosso sistema de financiamento de campanha se democratizou, nossa política tornou-se mais polarizada. Em 1990, as contribuições individuais para campanhas forneceram cerca de $25 \%$ do dinheiro da campanha, e os PACs forneceram cerca de metade; Hoje, os indivíduos são, de longe, a maior fonte de dinheiro direto para campanhas (cerca de $61 \%$ para o Congresso) e as contribuições de PAC representam menos de $25 \% .{ }^{67}$

Aqui está outro fato a ser mantido em mente ao procurar entender os indivíduos, a polarização e o dinheiro: a maioria das contribuições individuais vem agora de doadores fora do estado. ${ }^{68}$ Também não surpreende que os doadores fora do estado sejam os ideologicamente mais extremos de todos os doadores. Considere o tipo de indivíduos que provavelmente darão dinheiro de fora do estado para as campanhas de Elizabeth Warren e Ted Cruz, em oposição aos senadores mais moderados ou desafiadores sobre os quais a maioria dos doadores fora

${ }^{67}$ BARBER, Michael. Representing the Preferences of Voters, Partisans, and Donors in the U.S. Senate. Working Paper. 2014, p. 23. Disponível em:

$<$ http://citeseerx.ist.psu.edu/viewdoc/download?doi=10.1.1.668.1643\&rep=rep1\&type= pdf>. Acesso em: 14 de agosto de 2017. Números semelhantes são fornecidos no site Open Secrets, que rastreiam contribuições de campanhas. Disponível em:

$<$ https://www.opensecrets.org/resources/dollarocracy/04.php $>$. Acesso em: $14 \mathrm{de}$ agosto de 2017. Barber e McCarty colocaram o aumento na porcentagem das receitas de campanha oriundas de doadores individuais para os candidatos da Câmara, durante aproximadamente este mesmo período, passando de cerca de $50 \%$ para cerca de 75\%. BARBER, Michael; McCARTY, Nolan. Causes and Consequences of Polarization. In: Jane Mansbridge; Cathie Jo Martin (eds.). Negotiating Agreement in Politics. Washington, DC: American Political Science Association, 2013, p. 31. ${ }^{68} \mathrm{Um}$ estudo coloca a porcentagem de doações de fora do estado para os senadores titulares nas eleições de 2012 em aproximadamente $60 \%$ e conclui que os titulares geralmente aumentam de dez a quinze pontos percentuais mais dinheiro de doadores fora do estado, em relação ao total de suas doações, do que conseguem seus adversários. BARBER, Michael. Representing the Preferences of Voters, Partisans, and Donors in the U.S. Senate. Working Paper. 2014, p. 12. Disponível em: $<\underline{\text { http://citeseerx.ist.psu.edu/viewdoc/download?doi=10.1.1.668.1643\&rep=rep1\&type= }}$ pdf $>$. Acesso em: 14 de agosto de 2017.

3 JOURNAL OF INSTITUTIONAL STUDIES 1 (2017) 
do estado provavelmente sabem um pouco ou quase nada. ${ }^{69}$ Muitos eleitores individuais em todo o país provavelmente enviarão seu dinheiro para Missouri para Claire McCaskill ou para Tennessee para Lamar Alexander? A democratização das contribuições das campanhas através de vouchers pode, ironicamente, alimentar as chamas da polarização política, em comparação com os sistemas de financiamento público financiados de forma mais tradicional, através de receitas gerais.

Os proponentes de vouchers podem acreditar que os efeitos polarizadores de doações individuais desaparecerão uma vez que "todas as pessoas" tenham o poder de doar através de vales. Mas isso negligencia as dinâmicas de ação coletiva que influenciam toda a atividade política. As pessoas têm de se tornar motivadas e engajadas o suficiente para optar por doar e procurar informações relevantes para doações informadas - assim como elas devem votar - e informar e motivar os potenciais doadores levarão organização política e mobilização. Os que estão mais informados e motivados são provavelmente partidários e, portanto, os grupos mais capacitados para aproveitar essas novas oportunidades políticas - como em outras aberturas - também são mais partidários.

Eu digo tudo isso para não escolher propostas de voucher em particular, mas para ilustrar um ponto maior. A menos que atendamos às formas em que o poder político é realmente mobilizado, organizado, exercido e empacotado, então as propostas de políticas baseadas em uma visão individualista da política ou em ideais abstratos democráticos não fundamentados como "participação" ou "igualdade" pode contribuir perversamente para minar nossa capacidade institucional de governar.

Se quisermos adotar o financiamento público de maneiras menos propensas a alimentar a polarização partidária, as formas tradicionais de financiamento público através de receitas gerais, baseadas em doações individuais, poderiam ser mais apropriadas.

Passo agora a uma visão diferente: uma análise institucionalmente e organizacionalmente centrada na relação entre eleições, governança e poder político.

${ }^{69}$ Contribuições de pequenos doadores, inferiores a 200 dólares, por exemplo, contavam, em um resumo de 2013, como 64\% dos colaboradores dos mais polarizados Republicanos, tais como Michele Bachmann e Allen West, mas apenas 5\% das contribuições aos líderes de partidos, como Eric Cantor. Cf. KLEIN, Ezra. Small Donors May Make Politics Even Worse. Minnesota Lawyer. 2013. Disponível em: $<$ http://minnlawyer.com/2013/05/10/ezra-klein-small-donors-may-make-politics-evenworse/>. Acesso em: 14 de agosto de 2017. 


\section{PODER POLÍTICO, PARTIDOS POLÍTICOS}

Ao pensar sobre como permitir uma ação democrática eficaz através de nossas instituições políticas, devemos nos concentrar menos nos cidadãos individuais e mais nas entidades organizacionais atuais ou possíveis, que possuam incentivos mais poderosos para agregar a mais ampla gama de interesses à política democrática - e para forçar o compromisso, negociação e acomodação entre esses interesses. O poder organizacional inevitavelmente existe nas democracias; pode não ser desejável, mas é crucial para que a democracia possa funcionar. Das várias entidades organizacionais que existem ou que eu posso imaginar, os partidos políticos impulsionados pela necessidade de recorrer ao mais vasto eleitorado, continuam a serem os agregadores mais amplos de interesses diversos.

Esta proposição pode soar irônica, à luz do quão polarizados os partidos tornaram-se. Mas o incentivo eleitoral demonstra que ela permanece verdadeira. Os superpoderosos precisam juntar coalizões suficientemente amplas para controlar um, dois ou três das nossas instituições políticas nacionais e isso continua a ser a única força capaz de reunir diferentes gamas de interesses em duas grandes coligações e, ao fazê-lo, inevitavelmente, força o compromisso entre esses interesses. Quando os eleitores afro-americanos no sul foram autorizados a votar em três décadas depois da Guerra Civil, houve um efetivo trabalho interracial apesar das atitudes culturais da era sobre a raça. ${ }^{70}$ Os incentivos eleitorais e o desejo de manejar as ferramentas do poder político proporcionam grandes motivações para o compromisso dos grupos em busca de coalizões vencedoras. Nos sistemas eleitorais, os dois partidos políticos dominantes servem como o veículo principal para estes tipos de compromisso.

Não vejo outra possibilidade no horizonte. Recentemente, surgiram propostas para formar uma candidatura múltipla dos PAC que iria arrecadar e doar dinheiro para candidatos "moderados". ${ }^{71}$ Se essas

${ }^{70} \mathrm{Cf}$. GILMORE, Glenda Elizabeth. Gender and Jim Crow: Women and the Politics of White Supremacy in North Carolina, 1896-1920. Chapel Hill, NC: University of North Carolina, 1996, p. 78; KOUSSER, Joseph Morgan. The Shaping of Southern Politics: Suffrage Restriction and the Establishment of the One-Party South, 1880-1910. New Haven, CT: Yale University Press, 1974, p. 183; e PILDES, Richard. Democracy, AntiDemocracy and the Canon. Constitutional Commentary, Vol. 17, 2, 2000, p. 313-314. ${ }^{71}$ Cf., por exemplo, GLUECK, Katie. King Launches PAC. The Global Politico, Dec. 16, 2013. Disponível em: <http://www.politico.com/story/2013/12/peter-king-pac-2016election-101204.html>. Acesso em: 14 de agosto de 2017 (descrevendo o PAC de King 
entidades saírem do terreno, sou cético quanto à sua eficácia.

Mas, claro, a organização de uma candidatura múltipla que, par excellence, já existe é o partido político. De fato, as contribuições dos candidatos feitas por organizações de partidos políticos tendem a capacitar as forças do centro; partidos doam duas vezes mais aos candidatos no meio do processo ideológico espectro como para aqueles nos extremos. ${ }^{72}$ Contribuições de campanha baseadas em partidos

como um "veículo que o permitirá [a ele] percorrer o país para tentar encontrar Republicanos com a mesma opinião que não apoiam o desligamento do governo..."); HERNANDEZ, Raymond. Bloomberg Starts 'Super PAC,' Seeking National Influence. The New York Times, Oct. 27, 2012. Disponível em: $<$ http://www.nytimes.com/2012/10/18/nyregion/bloomberg-forming-super-pac-toinfluence-2012-races.html>. Acesso em: 14 de agosto de 2017 (descrevendo o objetivo do PAC de Bloomberg no sentido de "eleger candidatos de ambas os partidos que [Bloomberg] acredita que se concentrarão na resolução de problemas"); STRAUSS, Daniel. Super PAC to Defend Moderate Republicans against Tea Partiers. Talking Points Memo, Dec. 4, 2013. Disponível em: $<$ http://talkingpointsmemo.com/dc/defending-main-street-republicans $>$. Acesso em: 14 de agosto de 2017. Para o surgimento de PACs no nível estadual, cf. COOPER, Brad. New PAC Supports Moderate Kansas Republicans. The Wichita Eagle, Aug. 1, 2012. Disponível em: < $<$ http://www.kansas.com/2012/08/01/2432145/new-pac-supportsmoderate-kansas.html>. Acesso em: 14 de agosto de 2017 (relatando que o Republicano presidente do Senado "juntou-se a um par improvável com o trabalho organizado"); DAVE, Paresh. SEIU California Launches Republican PAC to Back Moderates. The Sacramento Bee, Jun. 9, 2011. Disponível em: $<$ http://blogs.sacbee.com/capitolalertlatest/2011/06/seiu-california-republicanpac.html>. Acesso em: 14 de agosto de 2017 (descrevendo os esforços de sindicatos da Califórnia para formar um PAC Republicano); HOEY, Dennis. Eliot Cutler to Launch PAC for Moderates. Portland Press Herald, Mar. 30, 2011. Disponível em: $<$ http://www.pressherald.com/news/cutler-to-launch-pac-for-moderates 2011-0330.html >. Acesso em: 14 de agosto de 2017 (descrevendo a formação de um PAC por Cutler para "candidatos 'de qualquer faixa' que estejam dispostos em trabalhar através das linhas partidárias"); e WHACK, Errin. Bolling Launches PAC to Recruit Mainstream Republicans in Virginia. The Washington Post, May 15, 2013. Disponível em: $<$ http://www.washingtonpost.com/local/va-politics/bolling-announces-launch-ofpac-to-recruit-mainstream-republicans-in-virginia/2013/05/15/81b1a2bc-bd6c-11e289c9-3be8095fe767 story.html>. Acesso em: 14 de agosto de 2017.

${ }^{72}$ LA RAJA, Raymond; SCHAFFNER, Brian. Do Party-Centered Campaign Finance Laws Increase Funding for Moderates and Challengers? Working Paper. 2014, p. 8/14; cf., ainda, GIERZYNSKI, Anthony; BREAUX, David. The Financing Role of Parties. In: 
tendem a ser uma forma de moderação em relação às contribuições individuais.

No entanto, é aqui que o problema da fragmentação política torna-se agudo. Os partidos, como todas as organizações, são entidades complexas compostas por muitos componentes, às vezes conflitantes, incluindo funcionários eleitos, líderes organizacionais, eleitores partidários, facções, e assim por diante. Entre essas forças, são os líderes eleitos do partido que têm os incentivos mais fortes para internalizar os incentivos eleitorais nacionais para amplas coalizões. O sucesso dos líderes do partido depende, em grande medida, de tornar a marca do partido tão ampla quanto mais atraente possível.

Lá, sugiro, reside o problema. A fragmentação política drenou os líderes eleitos partidários de grande parte do poder de controlar, unificar e disciplinar os membros de seu próprio partido. Por "fragmentação", quero dizer, tanto a difusão do poder nas eleições longe das campanhas formais como dos partidos políticos - e ainda mais importante, a difusão do poder no governo longe da liderança dos principais partidos políticos para suas facções mais extremas. Enquanto alguns caracterizaram as partes hoje como "redes"73, eu acredito que "politicamente fragmentado" captura melhor a estrutura.

Joel Thompson; Gary Moncrief (eds.). Campaign Finance in State Legislative Elections. Washington, DC: Congressional Quarterly Inc., 1998, p. 185/195-200 (descobrindo que partidos se dedicam mais fortemente a candidatos não-incumbentes em corridas competitivas).

${ }^{73}$ Cf., por exemplo, MASKET, Seth. Mitigating Extreme Partisanship in an Era of Networked Parties: an Examination of Various Reform Strategies. Center for Effective Public Management at Brookings Institution. 2014. Disponível em:

$<$ http://www.brookings.edu/ /media/research/files/papers/2014/03/20masket/masket mitigating-extreme-partisanship-in-an-era-of-networked-parties.pdf $>$. Acesso em: 14 de agosto de 2017. A ideia de partidos como redes de atores, no entanto, implica muito mais coordenação e ação unificada do que o caso. Como Masket reconhece, "o conceito de hierarquia não se encaixa bem no partido moderno". MASKET, Seth. Mitigating Extreme Partisanship in an Era of Networked Parties: an Examination of Various Reform Strategies. Center for Effective Public Management at Brookings Institution. 2014, p. 3. Disponível em: $<$ http://www.brookings.edu/ /media/research/files/papers/2014/03/20masket/masket mitigating-extreme-partisanship-in-an-era-of-networked-parties.pdf $>$. Acesso em: 14 de agosto de 2017. Esse é precisamente o meu ponto de vista, e é por isso que acredito que a "fragmentação política" descreve melhor a situação, particularmente na medida em que nosso propósito é entender a disfunção do governo. 
Nos recentes ciclos eleitorais, nos tornamos muito conscientes da fragmentação refletida na explosão das organizações Super PACs - 527 e 501(c) -, que procuram influenciar eleições e políticas. Muitas dessas organizações têm interesses políticos e ideológicos muito mais restritos do que os partidos como um todo. Ao mesmo tempo, os líderes do partido também têm menos capacidade para forçar os membros do partido a adotar a linha do partido. Os membros da Câmara e do Senado são muito mais capazes de funcionar como empresários independentes e agentes gratuitos. Como Moisés Naím documentou em uma ampla gama de organizações públicas e privadas, o "poder" organizacional está se desmembrando. ${ }^{74}$

Uma representação específica desse fenômeno é o poder sem precedentes que os senadores em seu primeiro ano de mandato têm em relação aos líderes de seus partidos e consequentemente sobre a nossa política. Os líderes do Partido Republicano podem ter entendido que fechar o governo e ameaçar o descumprimento seria destrutivo para os interesses do partido (eles não permitiram que o mesmo erro fosse feito duas vezes). Entretanto, hoje eles têm dificuldade para impedir que um ou alguns senadores em particular, ou uma facção minoritária, façam exatamente isso. É impossível imaginar uma figura tão poderosa como Lyndon Johnson, desempenhando o tipo de papel que Ted Cruz conseguiu desempenhar, em seu primeiro ano no Senado.

Para aqueles que pensam que esse tipo de fragmentação política é um problema apenas de um lado, eu discordo.$^{75}$ As mesmas forças estruturais

${ }^{74}$ Cf., em geral, NAÍM, Moisés. The End of Power: From Boardrooms to Battlefields and Churches to States, Why Being in Charge Isn't What It Used to Be. New York, NY: Basic Books, 2013.

${ }^{75}$ A fragmentação é uma questão diferente do tema muito discutido da polarização assimétrica; a última é a afirmação de que o Partido Republicano se moveu muito mais para a direita do que o Partido Democrata tem para a esquerda durante o período de intensa polarização partidária. Medido por padrões de votação nominal, há de fato evidências de que o Partido Republicano se moveu mais à direita desde a década de 1980 do que o Partido Democrata se moveu para a esquerda. Cf., por exemplo, HACKER, Jacob; PIERSON, Paul. Off Center: The Republican Revolution and the Erosion of American Democracy. New Haven, CT: Yale University Press, 2005, p. 5-7. Estudos que medem a ideologia de outras maneiras, contudo, concluem que os democratas do Congresso, desde 1980, moveram-se um pouco mais para a esquerda do que os republicanos do Congresso mudaram para a direita. Cf., por exemplo, BAILEY, Michael. Is Today's Court the Most Conservative in Sixty Years? Challenges and Opportunities in Measuring Judicial Preferences. Journal of Politics, Vol. 75, 3, 
estão em ação e o mesmo tipo de fragmentação está latente no Partido Democrata. Essas divisões irão se tornar evidentes sob o conjunto certo de circunstâncias. As forças do populismo econômico - centradas mais diretamente a partir de então sobre Elizabeth Warren, que já supostamente exerceram um veto efetivo sobre a escolha de seu próprio presidente para presidir o Federal Reserve $e^{76}$ - batalham com as forças mais os mais centristas dentro do Partido Democrata. Por enquanto, a presença de um presidente democrata em exercício exerce uma força unificadora suficiente para suprimir esses conflitos, mas uma vez que essa presença seja removida, poderemos ver uma fragmentação política mais aberta dentro do Partido Democrata.

Se você aceitar minha conclusão de que a polarização intensa dos partidos do governo é provavelmente um fato duradouro, a questão deve então mudar para o seguinte: de onde são as fontes de compromisso e negociação, acordos, pragmatismo e afins que provavelmente irão surgir em uma estrutura polarizada como essa? ${ }^{77}$ A polarização e o governo dividido tornam necessárias as capacidades e atitudes relacionadas ao

2013; e BONICA, Adam. Mapping the Ideological Marketplace. American Journal of Political Science, Vol. 58, 2, 2014.

${ }^{76}$ Cf. SCHEIBER, Noam. Hillary's Nightmare? A Democratic Party That Realizes Its Soul Lies with Elizabeth Warren. New Republic, Nov. 10, 2013. Disponível em: $<$ http://www.newrepublic.com/article/115509/elizabeth-warren-hillary-clintonsnightmare>. Acesso em: 14 de agosto de 2017: "Por seu lado, o governo Obama parece considerar Warren com sua devida cautela especial. Considere-se a campanha bemsucedida para bloquear a nomeação que se esperava de Larry Summers para a Direção da Federal Reserve. Brown e Merkley desempenharam papéis críticos para deter o impulso de Summers e emanar o voto 'não' entre os colegas Democratas. Mas a contribuição de Warren é difícil de exagerar. 'Elizabeth fez algo que só ela podia fazer', diz uma fonte próxima ao processo de seleção do presidente do Fed[eral Reserve], 'que foi lidar com a administração sobre o assunto e deixar claro que, se eles insistissem em avançar, todo o peso de sua capacidade poderia ser trazido à tona'. Isso 'foi uma ordem diferente de magnitude', diz a fonte, aludindo à enorme arrecadação de fundos de Warren - 42 milhões de dólares arrecadados para sua candidatura no Senado, metade disso online - e a seu magnetismo mediático. Um assessor de Warren não discute isso, dizendo apenas que 'ela passou suas preocupações para a Casa Branca'”.

77 Essas fontes de compromisso são ainda mais importantes se, como sugere a recente e abrangente análise em GROSSMANN, Matt. Artists of the Possible: Governing Networks and American Policy Change since 1945. New York, NY: Oxford University Press, 2014, a formulação de políticas for primariamente direcionada não por fatores externos, tais como eventos, opinião pública, ou cobertura da mídia, e sim pela agenda interna e pela negociação dentro do Congresso e entre Congresso e Casa Branca. 
compromisso - e, claro, mais difíceis. Em minha opinião, os líderes de partido eleitos são as fontes mais prováveis do tipo de compromisso político e pragmatismo necessário para reverter o declínio do governo americano.

Em parte, esse é um problema de números: as negociações entre três a cinco líderes são mais fáceis de conduzir do que as negociações em que as novas facções ou indivíduos surgem. Em parte, isso ocorre porque a confiança nas negociações, que é essencial para a negociação, é estabelecida por repetidos atores nas relações contínuas de negociação regular. Em segundo lugar, meu foco nos líderes de partidos eleitos decorre de uma crença empírica, refletida em estudos acadêmicos, de que os líderes partidários no Congresso tendem a serem "intermediários" ideológicos de seus partidos. ${ }^{78}$ Eles têm incentivos mais fortes para forjar compromissos, Amplos círculos eleitorais dentro de seus partidos e porque eles têm mais responsabilidade pessoal e culpa pelo fracasso de sua "instituição" funcionar efetivamente. ${ }^{79}$

${ }^{78}$ Cf. COX, Gary; McCUBBINS, Mathew. Legislative Leviathan: Party Government in the House. Berkeley, CA: University of California Press, 1993, p. 125-134; e KIEWIET, Roderick; McCUBBINS, Mathew. The Logic of Delegation: Congressional Parties and the Appropriations Process. Chicago, IL: Chicago University Press, 1991.

${ }^{79}$ Um artigo intrigante argumenta que, em meados da década de 1990, os líderes da maioria e da minoria da Câmara deixaram de ser os "intermediários" ideológicos que haviam sido durante muitas décadas e tornaram-se figuras ideológicas mais extremas do que os membros médios de seus caucuses. Cf. HEBERLIG, Eric, et. al.. The Price of Leadership: Campaign Money and the Polarization of Congressional Parties. Journal of Politics, Vol. 68, 4, 2006. A causa dessa mudança, afirmaram os autores, foi a importância crescente do dinheiro da campanha a partir de meados da década de 1990 (sob as estruturas legais existentes que determinavam os canais através dos quais o dinheiro poderia permissivamente fluir, eu acrescentaria), o que levou os membros a valorizar mais a capacidade dos líderes partidários de arrecadar fundos - e a disposição de redistribuí-los a outros membros e ao partido - do que uma representatividade ideológica. Como os extremistas ideológicos tendem a angariar mais fundos do que os moderados, essa mudança nas prioridades tem fortalecido as lideranças ideologicamente mais extremas da maioria e da minoria na Câmara. Esse resultado, líderes parlamentares que são extremos em relação a seus membros, no entanto, como refletido na Figura 1, baseia-se apenas em duas figuras na Câmara ao longo de três Congressos, o $104^{\circ}$ ao 107º, de 1994 a 2000 (quando Newt Gingrich se tornou o Presidente). HEBERLIG, Eric, et. al.. The Price of Leadership: Campaign Money and the Polarization of Congressional Parties. Journal of Politics, Vol. 68, 4, 2006, p. 993. Minha própria impressão casual é que, após os primeiros anos de 
Mas os líderes partidários só podem desempenhar esse papel se tiverem as ferramentas e a influência para trazerem seus caucuses na direção que esses líderes acreditam que melhor posiciona o partido como um todo. Finalmente, então, deixe-me explicar por que eles perderam essa influência.

O problema não é que os líderes individuais estejam agora "fracos". Parte da tendência americana de individualizar a política é focalizar as personalidades como a causa da ação política ou da inação política. As personalidades importam muito, mas a estrutura também. Tanto George W. Bush quanto Barack Obama fizeram campanha e tentaram governar através de acordos entre os partidos, mas ambos descobriram que a estrutura dos partidos hiperpolarizados no Congresso tornava este objetivo extremamente difícil..$^{80}$ Além disso, mudanças estruturais mais amplas, incluindo as mudanças legais, desarmaram os líderes partidários das ferramentas que anteriormente tinham usado para unificar seus membros em torno de negócios que eram pensados como de interesse do partido como um todo. Quais mudanças institucionais e estruturais podem retomar algumas das capacidades cruciais que permitem uma liderança partidária eficaz e, assim, também possibilitar uma governança eficaz?

\section{DECLÍNIO ESTRUTURAL NO PODER DOS LÍDERES PARTIDÁRIOS}

Os líderes de partido uma vez tiveram influência maior sobre seus membros através do poder de atribuições do comitê. Essas atribuições eram valiosas porque eram meios de trabalhar em questões substantivas que um membro se preocupava, formas de elevar o perfil e a estatura do membro e maneiras de levantar dinheiro para as eleições subsequentes.

Entretanto, duas mudanças importantes tornaram as atribuições dos

adaptação ao novo mundo do dinheiro da campanha, os líderes partidários nos anos subsequentes voltaram-se, na maior parte, a refletir mais o centro de seus caucuses do que os extremos. O livro subsequente sobre estas questões não atualiza as informações relativas à polarização das lideranças eleitas, tanto na Câmara, quanto no Senado, com relação ao membro médio do cáucus relevante. Cf. HEBERLIG, Eric; LARSON, Bruce. Congressional Parties, Institutional Ambition, and the Financing of Majority Control. Ann Arbor, MI: University of Michigan Press, 2012.

${ }^{80}$ Cf. PILDES, Richard. Why the Center Does Not Hold: The Causes of Hyperpolarized Democracy in America. California Law Review, Vol. 99, 2, 2011, p. 282-287. 
comitês menos significativas quando se trata da capacidade de levantar fundos e aumentar o status público e a visibilidade, pelo menos para os políticos que se veem como ascendentes (isto é, a maioria deles): a revolução das comunicações e o atual sistema de financiamento de campanhas. Os senadores politicamente ambiciosos, cada vez mais, veem o Senado como um passo rápido para uma campanha presidencial, particularmente devido ao sucesso do presidente Obama. De fato, permanecer no Senado por mais que um período curto pode ser considerado como um passivo na busca de um cargo superior, uma vez que um mandato mais longo significa uma maior necessidade de tomar posições em questões divididas, que inevitavelmente alienarão alguns potenciais eleitores.

A primeira mudança é uma questão cultural que todos nós reconhecemos: a revolução nas comunicações e na tecnologia da informação. De acordo com o relato de Moisés Naím, esta revolução é a principal força que desencadeia o desmantelamento geral da autoridade e da eficácia organizacional em setores públicos e privados..$^{81}$ Os titulares de cargos individuais agora têm capacidade para atingir grandes públicos, intensamente motivados, de potenciais eleitores e doadores de campanha de maneiras que não era possível antes; Eles são capazes de construir uma marca pessoal além do rótulo do partido. $\mathrm{O}$ senador Ted Cruz, por exemplo, passa mais tempo no Twitter e na televisão, incluindo a TV fechada, e discursos televisionados no chão na era pós-CSPAN, do que ele se encontra com líderes do Partido Republicano? O que Lyndon Johnson poderia ter feito que se compare a isso? Os líderes do partido não controlam e não podem desligar esses novos canais de acesso à comunicação direta com eleitores e doadores de campanha. Ao mesmo tempo que esses canais permitem que os funcionários individuais atinjam, eles também permitem uma maior influência populista para atingir os interesses partidários, uma vez que estes podem ser mais facilmente mobilizados. Obviamente, não há como diminuir essa evolução das comunicações.

A segunda força por trás dos líderes de partido de alavancagem reduzida sobre seus membros envolve mudanças legais. Aqui vou focar apenas na forma como mudamos o financiamento eleitoral a partir dos anos 70. Adotamos a estrutura reguladora mais agressiva da história americana para controlar o dinheiro nas eleições nacionais no início dos anos 70, na sequência de Watergate. $\mathrm{O}$ sistema que criamos era um

${ }^{81}$ Cf. NAÍM, Moisés. The End of Power: From Boardrooms to Battlefields and

Churches to States, Why Being in Charge Isn't What It Used to Be. New York, NY:

Basic Books, 2013. 
sistema de financiamento centrado no candidato, em contraste com os sistemas centrados no partido que são usados em grande parte da Europa. ${ }^{82}$ As emendas da Federal Election Campaign Act de $1974^{83}$ impuseram limites de contribuição e limites de gastos em campanhas em geral, e também tratavam os partidos políticos da mesma forma que os PACs corporativos e sindicais: os comitês partidários não podiam dar mais de US\$ 5 mil aos candidatos. Além disso, as contribuições individuais para as partes eram limitadas a US\$ 25.000 por ano ${ }^{84}$ Quando a Suprema Corte anulou os limites de gastos nesta lei em Buckley v. Valeo ${ }^{85}$, o Tribunal não fez praticamente nenhuma consideração em relação ao regulamento da lei de política partidária - nem em relação às restrições às doações dos partidos aos candidatos, nem aos limites das contribuições individuais para os partidos.

Então, no início dos anos 2000, acrescentamos a segunda grande mudança no nosso sistema de financiamento eleitoral: a campanha de McCain-Feingold financiava "reformas". Antes desse momento, os partidos políticos levantaram quase metade do seu dinheiro no que se chamava Soft Money. ${ }^{86}$ Sem se aprofundar em detalhes, o soft money

82 A Tillman Act de 1907 proibia que bancos e corporações nacionais contribuíssem para as campanhas nacionais, mas foi fracamente aplicada. A Hatch Act de 1940 iniciou com a concepção de regras de financiamento eleitoral mais baseadas em candidatos, colocando um limite de contribuição de 5.000 dólares em doações para partidos e um limite de 3.000.000 de dólares sobre o quanto os comitês nacionais de partidos poderiam arrecadar e gastar por ano. A Federal Election Campaign Act de 1971 limitou o montante que os candidatos (e suas famílias) poderiam dar às suas próprias campanhas; colocou limites sobre o quanto as campanhas poderiam gastar para o tempo da mídia; endossou a estrutura do PAC para corporações e sindicatos; impôs requisitos amplos e significativos de divulgação; e majorou (temporariamente, como se verificou) os limites sobre contribuições e gastos do partido. Para um breve resumo dessa história, cf. WALLISON, Peter; GORA, Joel. Better Parties, Better Government: a Realistic Program for Campaign Finance Reform. Washington, DC: AEI Press, 2009, p. 30-34.

${ }^{83}$ Cf. Public Law, No. 93-443 (1974).

${ }^{84}$ Os números em dólares destas restrições foram majorados pelas emendas de 1976. Cf. Amendments to Federal Election Campaign Act of 1971, Public Law, No. 94-283, 90 Stat. 475, 487 (1976).

${ }^{85}$ Cf. Buckley v. Valeo, 424 U.S. 1 (1976).

${ }^{86}$ Nos anos 1990, quando o soft money entrou em cena, proporcionou cerca de um terço das receitas dos partidos nacionais; pelo ciclo eleitoral de 1999-2000, que aumentou para $40 \%$ do total da renda nacional do partido. Cf. BRIFFAULT, Richard. Soft Money, Issue Advocacy, and the U.S. Campaign Finance Law. Elections Canada, May, 2002. 
envolveu contribuições para os partidos políticos que não estavam sujeitos aos limites da lei federal de financiamento de campanha. ${ }^{87}$ Esse soft money, que foi usado para ações de construção de partido (anúncios de televisão, positivos e negativos, referentes a candidatos específicos), foi totalmente divulgado e transparente quando o Congresso o eliminou. Algumas dessas contribuições foram em grandes quantidades; cerca da metade vem de indivíduos, o resto de corporações e sindicatos. ${ }^{88}$

Do ponto de vista dos reformadores, o soft money estava corrompendo. A solução de "purificação" no McCain-Feingold era proibir que os partidos recebessem qualquer soft money. A partir daí, todo o dinheiro dado aos partidos ficou sujeito a limites de contribuição. $O$ fato de o Congresso estar disposto a cortar o fluxo de dinheiro mole para os partidos foi por si só um sinal da natureza centrada no candidato do nosso sistema de financiamento e da dependência reduzida dos candidatos (especialmente dos que já ocupam cargos) nos partidos para atingir seu sucesso eleitoral. ${ }^{89}$ Mas o resultado prático agora parece ter

Disponível em:

<http://www.elections.ca/content.aspx?section=res\&dir=eim/issue5\&document=p3\&la

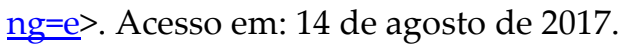

${ }^{87}$ Para uma completa explicação dos detalhes técnicos concernentes ao soft money, cf. BRIFFAULT, Richard. Soft Money, Issue Advocacy, and the U.S. Campaign Finance Law. Elections Canada, May, 2002. Disponível em:

<http://www.elections.ca/content.aspx?section=res\&dir=eim/issue5\&document=p3\&la

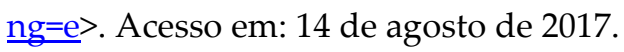

${ }^{88}$ Cf. BRIFFAULT, Richard. Soft Money, Issue Advocacy, and the U.S. Campaign Finance Law. Elections Canada, May, 2002. Disponível em: <http://www.elections.ca/content.aspx?section=res\&dir=eim/issue5\&document=p3\&la ng=e>. Acesso em: 14 de agosto de 2017 ("O tamanho do soft money também aumentou. Em 1997-1998, havia 390 indivíduos ou organizações - incluindo-se corporações empresariais, sindicatos, tribos nativas americanas e grupos ideológicos - que davam 100.000 dólares ou mais para as contas de soft money dos partidos políticos nacionais. Em 1999-2000, havia mais de mil doadores de 100.000 dólares ou mais em soft money, e 50 doadores de 1 milhão de dólares ou mais em soft money."). Ao total, na década anterior a McCain-Feingold, de 1991 a 2002, 51,5\% do dinheiro doado aos comitês partidários nacionais veio de indivíduos, do lado Democrata, e $48 \%$, do lado Republicano. Disponível em: $<$ https://www.opensecrets.org/parties/softsource.php $>$. Acesso em: 14 de agosto de 2017.

${ }^{89}$ Cf. BAUER, Robert. Of Fragmentation and Networks, and the State of Political Parties. More Soft Money Hard Law, Feb. 19, 2014. Disponível em: 
sido o de diminuir os partidos políticos já enfraquecidos como uma forma de fortalecer as eleições e criar incentivos para que esse partido soft money flua para grupos independentes. Mesmo "o jogo de caça" das eleições, a atividade eleitoral do partido por excelência, é cada vez mais financiada fora dos partidos. ${ }^{90}$

No mesmo momento em que os legisladores conseguiram se promover e arrecadar dinheiro independentemente dos partidos, os partidos foram dramaticamente desarmados em relação a outros grupos. Pior ainda, as "reformas" ao financiamento de campanhas ativamente encorajaram o fluxo de dinheiro dos partidos para organizações que apoiavam causas mais restritas e sectárias. É por isso que os senadores, em seu primeiro ano, agora podem exercer tanto poder dentro e sobre seus partidos quanto os mais antigos, incluindo a liderança do partido.

\section{UM SISTEMA DE FINANCIAMENTO DE CAMPANHA BASEADO EM PARTIDOS}

Uma vez que não podemos desfazer a revolução das comunicações, quero sugerir três propostas de mudanças legais destinadas a dar aos partidos políticos - e tão importante quanto a sua liderança eleita - mais influência nas eleições e, portanto, sobre como seus membros governam. Mudanças legais podem não ser necessárias para fortalecer a liderança partidária; é possível que processos orgânicos, impulsionados por incentivos eleitorais nacionais, o façam. ${ }^{11}$ Mas se as mudanças legais se

$<$ http://www.moresoftmoneyhardlaw.com/2014/02/fragmentation-networks-statepolitical-parties $>$. Acesso em: 14 de agosto de 2017.

${ }^{90}$ Cf., por exemplo, EGGEN, Dan. Outside Groups Plan To Focus on Air War, Ground Game in 2012 Election Fight. The Washington Post, Apr. 20, 2012. Disponível em: $<$ http://www.washingtonpost.com/politics/outside-groups-plan-to-focus-on-air-warground-game-in-2012-election-fight/2012/04/20/gIQAw6beWT story.html >. Acesso em: 14 de agosto de 2017.

${ }^{91}$ Cf., por exemplo, BALL, Molly. How the GOP Establishment Tea-Partied the Tea Party. The Atlantic, Nov. 6, 2013. Disponível em:

$<$ http://www.theatlantic.com/politics/archive/2013/11/how-the-gop-establishment-teapartied-the-tea-party/281208>. Acesso em: 14 de agosto de 2017; KING, JR., Neil. GOP Pushes Back on Tea Party. The Wall Street Journal, Oct. 9, 2013. Disponível em: $<$ https://www.wsj.com/articles/gop-pushes-back-on-tea-party-1381361910>. Acesso em: 14 de agosto de 2017; LIPTON, Eric, et. al.. Business Groups See Loss of Sway over House G.O.P.. The New York Times, Oct. 9, 2013. Disponível em: 
revelarem necessárias, eu ofereço estas três sugestões iniciais. As duas primeiras mudanças são modestas, a terceira mais dramática. As especificidades de qualquer uma dessas propostas são menos importantes (e não desenvolvidas aqui em detalhes) do que a reorientação conceitual geral que tenho em mente: capacitar os partidos políticos e seus líderes de modo que as forças agregadoras da democracia sejam poderosas e vantajosas, dentro do processo democrático.

Essas propostas se concentram em mudar nossas políticas de financiamento de campanha para dar um papel maior aos partidos políticos. Como Ray LaRaja e Brian Schaffner demonstraram recentemente, os estados que têm mais leis de financiamento de campanha "centradas no partido" tendem a ter legislaturas menos polarizadas do que aqueles que tentam impor restrições significativas sobre os meios pelos quais os partidos políticos podem apoiar os candidatos. $^{92}$ Eles concluem que os partidos tendem a usar seus recursos financeiros para apoiar candidatos moderados mais do que outras fontes de dinheiro da campanha; de acordo com as estruturas de incentivo que descrevi acima, os candidatos eleitos que controlam as organizações partidárias internalizam as eleições vencedoras em detrimento da pureza ideológica. A evidência empírica mostra que os partidos, mais do que grupos de discussão e outros comitês políticos, tendem a concentrar seu dinheiro em candidatos moderados e não em candidatos ideólogos. Como resultado, LaRaja e Schaffner argumentam que dar mais liberdade

$<$ http://www.nytimes.com/2013/10/10/us/business-groups-see-loss-of-sway-overhouse-gop.html?pagewanted=all>. Acesso em: 14 de agosto de 2017; ROBERTSON, Campbell. Byrne Wins Republican Runoff in Alabama House Race. The New York Times, Nov. 5, 2013. Disponível em: $<$ http://www.nytimes.com/2013/11/06/us/politics/tea-party-republican-loses-alabamarunoff.html>. Acesso em: 14 de agosto de 2017 (relatando que o forte apoio das empresas auxiliou o vencedor a derrotar o candidato apoiado pelo Tea Party em uma primária Republicana); e WEISMAN, Jonathan. In Mississippi, It's G.O.P. vs. Tea Party. The New York Times, Mar. 26, 2014. Disponível em: $<$ http://www.nytimes.com/2014/03/27/us/politics/mississippi-senate-race-boils-downto-gop-vs-tea-party.html $>$. Acesso em: 14 de agosto de 2017 (descrevendo os atores da hegemonia Republicana que trabalham para apoiar o Senador Thad Cochran contra um desafio do Tea Party).

${ }^{92}$ Cf. LA RAJA, Raymond; SCHAFFNER, Brian. Want to Reduce Polarization? Give Parties More Money. The Washington Post, Jul. 21, 2014. Disponível em: $<\underline{\text { http://www }}$ .washingtonpost.com/blogs/monkey-cage/wp/2014/07/21/want-to-reduce-polarizationgive-parties-more-money>. Acesso em: 14 de agosto de 2017. 
aos partidos políticos no sistema de financiamento de campanha resulta em legislaturas menos polarizadas. ${ }^{93}$

O sistema federal de financiamento de campanha impõe limites sobre o quanto os partidos políticos podem contribuir diretamente para as campanhas de seus candidatos. ${ }^{94}$ Mas as regras de financiamento de campanha também tratam as despesas de campanha de um ator que são coordenadas com a campanha de um candidato como equivalente a uma contribuição direta para aquela campanha. Além disso, embora as regras sejam mais generosas em termos de dólares para as partes ${ }^{95}$, essas regras tratam de forma similar as despesas coordenadas dos partidos, além desses montantes como contribuições proibidas para a campanha do candidato. $\mathrm{O}$ medo é que os gastos do partido, em coordenação com seu candidato, sejam um canal para que os indivíduos contornem os limites de contribuição que existem em doações diretas para a campanha e que as proibições sobre a afetação de contribuições dos partidos para candidatos específicos não são suficientes para resolver esta preocupação. ${ }^{96}$ O medo é que o gasto do partido em coordenação com seu

${ }^{93}$ LA RAJA, Raymond; SCHAFFNER, Brian. Want to Reduce Polarization? Give Parties More Money. The Washington Post, Jul. 21, 2014. Disponível em: $<$ http://www .washingtonpost.com/blogs/monkey-cage/wp/2014/07/21/want-to-reduce-polarizationgive-parties-more-money >. Acesso em: 14 de agosto de 2017.

${ }^{94}$ Para uma descrição e análise gerais de como as leis de financiamento de campanha regulam o financiamento ligado aos partidos políticos, cf. BRIFFAULT, Richard. The Political Parties and Campaign Finance Reform. Columbia Law Review, Vol. 100, 3, 2000; e PERSILY, Nathaniel. Soft Parties and Strong Money. Election Law Journal, Vol. $3,2,2004$

${ }_{95}$ Em 2013, um partido poderia fazer 46.600 dólares em despesas coordenadas com um candidato da Câmara num estado com mais de um membro da Câmara (93.100 dólares em Estados com apenas um membro da Câmara); para o Senado, o montante depende do tamanho da população do Estado e varia de números como 9.000 dólares, em Maine, a 1.425.000 dólares, em Nova York. Veja o site da FEC para estes números. Disponível em: $<$ https://www.fec.gov/updates/2013-coordinated-party-expenditurelimits/>. Acesso em: 14 de agosto de 2017.

${ }_{96}$ Cf. 2 U.S.C. $\$ 441 a$ (d)(3)(B)(4) (2012); 11 C.F.R. $§ 109.21$ (d)(1)-(3) (2012). Cf., ainda, BAUER, Robert. The Right to "Do Politics" and Not Just To Speak: Thinking About the Constitutional Protections for Political Action. Duke Journal of Constitutional Law \& Public Policy, Vol. 9, 1, 2013 (argumentando que a coordenação envolve interesses associativos que têm pouca preocupação na jurisprudência de financiamento de campanha); HASEN, Richard. Super PAC Contributions, Corruption, and the Proxy War over Coordination. Duke Journal of Constitutional Law \& Public Policy, Vol. 9, 2, 2014; SMITH, Bradley. Super PACs and the Role of "Coordination" in Campaign 
candidato seja um canal para que os indivíduos contornem os limites de contribuição que existem em doações diretas para a campanha e que a proibição de destinar contribuições de partidos para candidatos específicos não seja suficiente para resolver esta preocupação.

O efeito (e intenção) é usar a lei de financiamento de campanha para tentar construir mais um muro entre os partidos políticos e seus candidatos quando se trata de gastar dinheiro em eleições. Na verdade, a Comissão Eleitoral Federal queria ir ainda mais longe e tratar qualquer dinheiro gasto por um partido para apoiar um candidato como uma contribuição direta para o candidato, o que significaria que este dinheiro estaria sujeito a bonificações de contribuição. A Suprema Corte parou esse esforço afirmando que os gastos dos partidos políticos que são independentes são tão protegidos pela Primeira Emenda como gastos independentes por qualquer outra entidade. ${ }^{97}$ Mas ainda vivemos com os constrangimentos residuais que a Suprema Corte endossou: impor limites à capacidade dos partidos políticos de coordenar gastos eleitorais com seus candidatos. ${ }^{98}$ De fato, a Suprema Corte rejeitou qualquer opinião de que deveria ser aplicado um escrutínio mais rigoroso aos limites das despesas coordenadas dos partidos do que a de qualquer

Finance Law. Willamette Law Review, Vol. 49, 4, 2013 (observando que "ainda há muito pouca análise da teoria da coordenação e das despesas independentes, por tribunais ou comentaristas" em todos os anos desde Buckley v. Valeo, 424 U.S. 1 (1976)); BAUER, Robert. Coordinating with a Super PAC, Raising Money for It, and the Difference between the Two. More Soft Money Hard Law, Jan. 27, 2014. Disponível em: $<$ http://www.moresoftmoneyhardlaw.com/2014/01/coordinating-super-pacraising-money-difference-two>. Acesso em: 14 de agosto de 2017.

${ }_{97}$ Colorado Republican Federal Campaign Committee v. Federal Election Commission, 518 U.S. 604, 615-616 (1996).

98 Cf. Federal Election Commission v. Colorado Republican Federal Campaign Committee, 533 U.S. 431 (2001) (mantendo as limitações sobre os gastos coordenados de partidos); Colorado Republican Federal Campaign Committee v. Federal Election Commission, 518 U.S. 604 (1996) (em uma decisão de pluralidade, eliminando as limitações sobre as despesas independentes de partidos). A FEC havia inicialmente adotado a posição de que "todas as despesas do comitê [de um partido] que são atribuíveis a uma eleição individual devem ser consideradas como coordenadas". Colorado Republican Federal Campaign Committee v. Federal Election Commission, 518 U.S. 604 (1996), Brief for Respondent, p. 30; cf. Colorado Republican Federal Campaign Committee v. Federal Election Commission, 518 U.S. 604 (1996), Brief for Respondent, p. 28-30 (trazendo o mesmo argumento). 
outra entidade..$^{99}$

Minha primeira proposta, portanto - e pode parecer surpreendente é permitir que os partidos trabalhem mais diretamente com seus candidatos e coordenar os gastos do partido com as campanhas. Os doadores devem continuar a não ter a possibilidade de reservar as doações para candidatos específicos ${ }^{100}$, e podem levantar preocupações sobre a eficácia dessas proibições de afetação das doações, mas a questão da corrupção potencial deve ser vista em termos comparativos: num mundo em que os indivíduos podem contribuir com quantidades ilimitadas de Super PACs de promoção de questões, incluindo Super PACs dedicados a um candidato específico ou questão específica ${ }^{101}$, será que estamos limitando melhor as contribuições aos partidos ou a sua capacidade de se engajar em gastos coordenados com os candidatos? Os partidos, afinal, são constituídos por numerosos interesses e muitos doadores, incluindo grandes doadores; os partidos diluem o papel do dinheiro reunindo tantos interesses e doadores. Esta diluição está longe de ser completa, é claro, mas, novamente, é provavelmente melhor do que as alternativas. Em vez de tratar a cooperação entre partidos e candidatos como veículos potenciais através dos quais os indivíduos podem corromper candidatos, devemos reconhecer que, no equilíbrio, as despesas coordenadas pelo partido têm, pelo menos, a virtude de vincular de maneira mais eficaz os partidos e os candidatos. Esse vínculo ajudaria a reavivar um papel mais central dos comitês nacionais de campanha dos partidos no sucesso de seus candidatos e, por sua vez, daria aos líderes de partidos mais força sobre os candidatos.

Minha segunda modesta proposta é aumentar significativamente os montantes de dinheiro que podem ser doados para partidos políticos para fins eleitorais. É importante reconhecer, embora seja complexo de desvendar, como a proibição da McCain-Feingold sobre as contribuições de soft money afetou o dinheiro total disponível para os partidos e, portanto, o papel dos partidos, em relação a outras entidades, no processo democrático. Deixe-me oferecer apenas dois fatos rápidos para ilustrar como a proibição desta lei sobre soft Money afetou imediatamente o financiamento eleitoral. McCain-Feingold, pelo menos tanto ou mais do

${ }^{99}$ Cf. Federal Election Commission v. Colorado Republican Federal Campaign Committee, 533 U.S. 431, 456 (2001).

1002 U.S.C. $\S 441 a(a)(8)$ (2012) estipula que as contribuições de um indivíduo ou de um PAC que "sejam de alguma forma afetadas ou direcionadas de outra forma por um intermediário ou condutor" a um candidato "serão tratadas como contribuições de tal pessoa para tal candidato."

${ }^{101}$ Cf. BRIFFAULT, Richard. Super PACs. Minnesota Law Review, Vol. 96, 5, 2012. 
que Citizens United, explica o papel das entidades não partidárias no modo como as nossas eleições são realizadas atualmente.

Na primeira eleição após a promulgação da lei, em 2004, os partidos políticos pareciam poder efetivamente substituir o soft money que haviam perdido por meio de esforços crescentes e bem sucedidos para arrecadar mais dinheiro de mais indivíduos, em parte porque McCain-Feingold também levantou a quantia de dinheiro que os indivíduos podiam doar para os partidos. ${ }^{102}$ Mas a lei também logo encorajou um aumento dramático nos gastos de grupos fora da estrutura do partido. A partir de 2002, quando a lei foi adotada, até 2008 - bem antes de Citizens United foi decidido em janeiro de 2010 - a despesa independente por entidades não partidárias explodiu, crescendo cerca de $1122 \%$ naqueles 6 anos (ou 555\% a partir de 2000, a eleição presidencial antes da lei). ${ }^{103}$ Nas eleições de 2012, as despesas não-partidárias cresceram apenas $207 \%$ em relação às eleições de 2008, embora as eleições de 2012 tivessem sido altamente competitivas até o fim. ${ }^{104} \mathrm{O}$ dinheiro que estava indo para os partidos e não poderia mais simplesmente fluir agora para gastos independentes daqueles que eram antes dados aos partidos. Paralelamente, as despesas dos partidos políticos parecem ter tido um impacto significativo. ${ }^{105}$

Tenha isso em mente na próxima vez que você ouvir Citizens United castigado como "a raiz de todo o mal" sobre o dinheiro na política. Esse ponto de vista é errado, por muitas razões para enfrentar aqui, e os Citizens United se tornaram um poste de chicote muito conveniente para aqueles que se preocupam com um papel excessivo do dinheiro nas eleições americanas. ${ }^{106} \mathrm{Na}$ verdade, os Citizens United desempenharam

${ }^{102}$ Cf. PILDES, Richard. Foreword: The Constitutionalization of Democratic Politics.

Harvard Law Review, Vol. 118, 29, 2004, p. 144-145.

${ }^{103}$ Cf. Disponível em: <https://www.opensecrets.org/outsidespending/cycle tots.php $>$.

Acesso em: 14 de agosto de 2017.

${ }^{104}$ Esses números são calculados a partir de dados fornecidos pelo OpenSecrets.org e incluem gastos não-partidários para gastos independentes, comunicações eleitorais e custos de comunicação no total ao longo desses anos.

${ }_{105}$ Cf., por exemplo, KELNER, Robert; LA RAJA, Raymond. McCain-Feingold's

Devastating Legacy. The Washington Post, Apr. 11, 2014. Disponível em:

$<$ https://www.washingtonpost.com/opinions/mccain-feingolds-devastatinglegacy/2014/04/11/14a528e2-c18f-11e3-bcec-

$\underline{b 71 e e 10 e 9 b c 3}$ story.html?utm term=.37d3d3181f5c $>$. Acesso em: 14 de agosto de 2017.

106 Francis Barry fornece uma breve explicação de algumas dessas razões: “Este direito mais amplo de se engajar em advocacia expressa tem dado aos doadores ricos uma outra opção além de enviar grandes cheques. Esses cheques, no entanto, são cada vez 
um papel secundário na recente explosão de dinheiro não partidário. Em parte, porque a lógica de Buckley tornou inevitável que a Primeira Emenda proibisse limites sobre doações a entidades não partidárias que se envolviam apenas em gastos eleitorais independentes. ${ }^{107}$ Reformas como a proibição do soft money de McCain-Feingold criou pelo menos um forte incentivo para o aumento das forças centrípetas e fragmentárias na democracia, tal como o fizeram os Citizens United. Em um mundo em que o potencial poço de dinheiro se torna efetivamente ilimitado para influenciar os resultados eleitorais, porque Buckley v. Valeo faz todo tipo de limitações de gastos inconstitucionais, restrições ao fluxo de dinheiro para candidatos e as campanhas inevitavelmente levam esse dinheiro a fluir através de outros canais, como ocorreu nas inundações bem antes dos Citizens United. ${ }^{108}$ Para aqueles que continuam preocupados com o fluxo de dinheiro para os partidos políticos, podemos debater limites apropriados de montantes e fontes. Mas se tivermos limites nos montantes que podem ser doados a partidos de fontes apropriadas, então

mais enviados a grupos que não foram afetados pelas decisões de Citizens United e Speechnow: organizações do 501(c) que, como os velhos PACs furtivos, não precisam divulgar seus doadores. Governadas mais pela Internal Revevue Service do que pela Federal Election Commission, a atividade eleitoral desses grupos é mais restrita do que a dos comitês políticos, mas a supervisão sempre foi branda. De 2004 a 2012, as despesas de organizações do 501(c) cresceram quase 500 por cento, para 334 milhões de dólares de menos de 60 milhões. No mesmo período, a despesa total de 527 grupos caiu $65 \%$, para 151 milhões de dólares, de 431 milhões. Parte do dinheiro faltante foi indubitavelmente para as organizações do 501(c) e uma outra parte dele foi para os Super PACs, que levantaram 609 milhões de dólares em 2014. Mas vamos colocar estes números no contexto. A despesa total dos comitês políticos que aceitam contribuições ilimitadas (Super PACs e os do 527) cresceu 76\% entre 2004 e 2012. Entretanto, as contribuições totais dos dois principais partidos dos candidatos presidenciais cresceram 72\%, passando de 696 milhões de dólares, em 2004, para 1,2 bilhões em 2012." BARRY, Francis. Forget the Dictionary, Super PACs aren't New. Bloomberg View, Mar. 21, 2014.

${ }^{107}$ Um estudo recente sobre a despesa independente a nível estadual, tanto antes, como depois de Citizens United, concluiu que a decisão "não teve grande influência direta nos gastos das empresas, apesar das expectativas públicas". HAMM, Keith, et. al. Independent Spending in State Elections: Vertically Networked Political Parties Have Been the Real Story. Working Paper. 2014, p. 1. Disponível: $<$ http://www.cfinst.org/pdf/state/hamm-kettler-malbin-glavin state-indep-spdg 20062010 webversion.pdf $>$. Acesso em: 14 de agosto de 2017.

108 Cf., em geral, ISSACHAROFF, Samuel; KARLAN, Pamela. The Hydraulics of Campaign Finance Reform. Texas Law Review, Vol. 77, 7, 1999. 
esses limites devem ser estabelecidos em níveis altos para encorajar um papel mais efetivo para os partidos nas eleições e, portanto, na governança.

Nesse sentido, tanto aumentar as cotas para as doações a partidos, quanto para os gastos com o partido, coordenado com os seus candidatos, levanta a preocupação de que os doadores possam usar os partidos para corromper as pessoas no cargo, fazendo depender os eleitos de grandes contribuições para os partidos - doações que são então passadas para candidatos específicos que estão cientes da fonte final dos gastos ou contribuições da participação. A minha proposta final, mais extrema, leva, portanto, à sua conclusão natural, a ideia subjacente de estruturar o sistema de financiamento das campanhas para apoiar um papel mais amplo dos partidos políticos, de forma a abordar esta questão da corrupção. Poderíamos considerar uma mudança para as eleições publicamente financiadas, mas com a importante reviravolta de que elas sejam financiadas significativamente pelos partidos políticos, ao invés de ter os candidatos individuais como o destinatário exclusivo ou esmagador dos fundos. Nas experiências limitadas de financiamento público nos estados, o dinheiro atravessa esmagadoramente os candidatos, e não os partidos - refletindo a típica concepção americana da democracia baseada no individualismo. ${ }^{109}$

O financiamento público através dos partidos atingiria mais diretamente o objetivo de colocar maior alavancagem nas mãos dos líderes partidários. Seria também, talvez não por acaso, trazer o nosso sistema de financiamento das eleições para mais perto do sistema mais

${ }^{109}$ Quatorze Estados fornecem financiamento público aos candidatos, que concordam, em troca, com os limites de suas despesas de campanha. Na maioria dos Estados, os fundos públicos compõem uma parcela do financiamento de um candidato, mas os candidatos podem continuar a levantar o dinheiro regulado de fontes privadas; em Estados de "eleição limpa", os candidatos que aceitam financiamento público não podem levantar quaisquer fundos privados adicionais. Dez Estados fornecem pequenas quantias de dinheiro para os partidos políticos, geralmente para ajudar a financiar as convenções do partido; essas subvenções "geralmente não são grandes". Cf., em geral, NATIONAL CONFERENCE OF STATE LEGISLATURES. Overview of State Laws on Public Financing. 2013. Disponível em:

$<$ http://www.ncsl.org/research/elections-and-campaigns/public-financing-ofcampaigns-overview.aspx>. Acesso em: 14 de agosto de 2017 (fornecendo uma visão geral de financiamento público estadual e campanhas). 
comum utilizado em outras democracias bem estabelecidas. ${ }^{110}$ Naturalmente, se fomentássemos ou exigíssemos que o dinheiro fluísse através dos principais partidos políticos, seria ainda mais importante centrar-se na forma como a liderança dos partidos se constitui e, dado o significado muito maior que os partidos teriam, as maneiras pelas quais esses líderes de partido são escolhidos iriam mudar (especialmente para o partido que não controla a presidência). Com base nos pontos de vista aqui delineados, talvez as organizações partidárias em curso, a Convenção Nacional Democrática e a Convenção Nacional Republicana precisassem ser colocadas sob o controle da liderança do partido eleito no governo, pelo menos para as determinações de como usar os fundos da campanha. Líderes nacionais eleitos do partido (um grupo de vários membros de tais líderes pode ser apropriado) continuam a ser os mais propensos a internalizar os incentivos para fazer o partido atraente para um amplo eleitorado. Mas fixar os detalhes é menos importante do que gerar discussão sobre essa direção geral para os esquemas de financiamento público.

É possível, é claro, que os desenvolvimentos orgânicos possam mover a dinâmica política nessa direção sem mudanças políticas formais. O ciclo eleitoral de meados de 2014, por exemplo, viu surgir, para o Senado, um Super PAC excepcionalmente bem financiado no lado democrata, o Senate Majority PAC, que é financiado por bilionários individuais que fazem grandes contribuições (sendo a maior de US\$ 5 milhões) e uniões trabalhistas. ${ }^{111}$ Bem como os amplos objetivos eleitorais de um partido

${ }_{110}$ A maioria dos países da Europa Ocidental concede subsídios anuais aos partidos políticos, normalmente baseados tanto no número de votos recebidos, quanto no número de lugares legislativos ocupados pelo partido, ou em alguma combinação dos dois. Para uma descrição dos arranjos de financiamento público em cinco desses países, cf. NASSMACHER, Karl-Heinz. Party Funding in Continental Western Europe. In: Reginald Austin; Maja Tjernström (eds.). Funding of Political Parties and Election Campaigns. Stockholms: International Institute for Democracy and Electoral Assistance, 2003, p. 117/122-126. Informações sobre quais países usam financiamento público como parte de seu sistema de finanças políticas estão disponibilizadas em OHMAN, Magnus. Political Finance Regulations around the World: an Overview of the International IDEA Database. Stockholm: International Institute for Democracy and Electoral Assistance, 2012.

${ }^{111}$ Cf. GOLD, Matea. Top Harry Reid Advisers Build Big-Money Firewall To Protect Senate Democrats. The Washington Post, Sept. 16, 2014. Disponível em: <https://www.washingtonpost.com/politics/top-harry-reid-advisers-build-big-moneyfirewall-to-protect-senate-democrats/2014/09/16/991381b6-3cdf-11e4-9587-

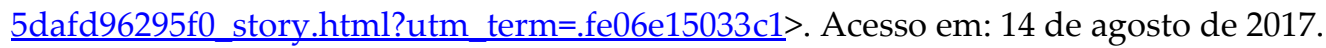


político, o objetivo deste Super PAC é preservar a maioria democrata no Senado. ${ }^{112} \mathrm{O}$ partido, portanto, gastou grandes quantias para tentar preservar os assentos de senadores vulneráveis, porém competitivos, que por sua vez significam os senadores mais centristas do Partido Democrata, provenientes de estados azuis ou vermelhos, como o senador Pryor do Arkansas, o senador Hagan da Carolina do Norte e o senador Begich do Alasca. ${ }^{113}$

Este PAC se comporta como um partido político no sentido de que seu objetivo não é apoiar os puristas ideológicos, mas em termos mais pragmáticos e eleitoralmente orientados, apoiar os candidatos vulneráveis do partido, independentemente de uma ideologia específica. Dado o relato teórico e empírico que eu forneci anteriormente, não deveria surpreender que os organizadores e líderes deste PAC tenham fortes conexões profissionais com o líder da maioria do Senado, Harry M. Reid $^{114}$, ou que o presidente Obama tenha falado tenha falado em dois dos

112 GOLD, Matea. Top Harry Reid Advisers Build Big-Money Firewall To Protect Senate Democrats. The Washington Post, Sept. 16, 2014. Disponível em: <https://www.washingtonpost.com/politics/top-harry-reid-advisers-build-big-moneyfirewall-to-protect-senate-democrats/2014/09/16/991381b6-3cdf-11e4-9587-

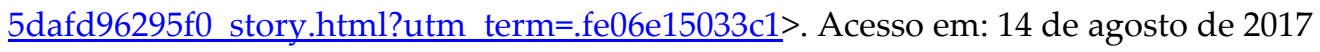
("A equipe do PAC da maioria no Senado se reuniu no início de 2011, assombrada por derrotas apertadas de senadores Democratas no ano anterior em Estados como Illinois e Pensilvânia").

${ }^{113}$ GOLD, Matea. Top Harry Reid Advisers Build Big-Money Firewall To Protect Senate Democrats. The Washington Post, Sept. 16, 2014. Disponível em: <https://www.washingtonpost.com/politics/top-harry-reid-advisers-build-big-moneyfirewall-to-protect-senate-democrats/2014/09/16/991381b6-3cdf-11e4-9587-

5dafd96295f0 story.html?utm term=.fe06e15033c1>. Acesso em: 14 de agosto de 2017 ("Quando o Senador Mark Pryor foi golpeado com anúncios na primavera passada... o [PAC da maioria no Senado] bateu de volta no desafiante Republicano de Pryor... O PAC da maioria no Senado e a Patriot Majority gastaram milhões defendendo o Senador Kay Hagan... No Alasca, o PAC da maioria do Senado proporcionou a maior parte do financiamento para... um Super PAC, apoiando o Senador Mark Begich."). ${ }^{114}$ GOLD, Matea. Top Harry Reid Advisers Build Big-Money Firewall To Protect Senate Democrats. The Washington Post, Sept. 16, 2014. Disponível em: $<$ https://www.washingtonpost.com/politics/top-harry-reid-advisers-build-big-moneyfirewall-to-protect-senate-democrats/2014/09/16/991381b6-3cdf-11e4-95875dafd96295f0 story.html?utm term=.fe06e15033c1>. Acesso em: 14 de agosto de 2017 (descrevendo o PAC como "liderado por um quarteto de estrategistas políticos com próximos laços com o Senador Reid"). 
maiores PAC arrecadatórios. ${ }^{115}$ Embora o senador Reid não controle formalmente este PAC, pode-se especular confortavelmente que se este PAC (como o maior gastador externo do lado democrata) conseguir permitir a eleição de senadores democratas, o senador Reid Poderia muito bem acabar com uma maior capacidade de "persuadir" os senadores a seguir as posições da liderança. Se PACs semelhantes, estreitamente ligados à liderança, surgem em ambos os lados nas duas casas do Congresso, os líderes partidários podem muito bem acabar com maior alavancagem sobre os membros da base dependentes desta fonte de financiamento.

Essas grandes contribuições para as entidades "não partidárias" de gastos independentes estão fluindo para o Partido Democrata, e não para os órgãos da própria organização partidária (como o Comitê Democrático de Campanha do Senado), porque a lei atual não permite que os partidos políticos aceitem doações não limitadas que serão usadas apenas para se engajarem em gastos independentes. Mas o litígio atual está desafiando essa restrição de motivos da Primeira Emenda, com base no argumento de que os partidos políticos, como outras entidades, devem ser capazes de aceitar doações ilimitadas se forem usadas apenas para o direito constitucionalmente protegido do partido de se engajar em gastos independentes. ${ }^{116}$ Há poucas dúvidas de que, se as organizações do Partido Democrata pudessem aceitar essas contribuições ilimitadas e independentes, então uma entidade como a PAC maioria do Senado desapareceria da noite para o dia, e todo ou quase todo esse dinheiro fluirá para a organização partidária apropriada (Mais Super PACs orientados ideologicamente continuariam a existir). Além disso, se esse litígio for bem-sucedido, isso reduziria significativamente a importância das questões que eu criei sobre os limites das despesas coordenadas pelo partido ou sobre o limite nas bonificações de doações para os partidos em dinheiro que será usado para contribuições para campanhas, e não para gastos independentes. Se os partidos políticos tivessem o direito

115 GOLD, Matea. Top Harry Reid Advisers Build Big-Money Firewall To Protect Senate Democrats. The Washington Post, Sept. 16, 2014. Disponível em: <https://www.washingtonpost.com/politics/top-harry-reid-advisers-build-big-moneyfirewall-to-protect-senate-democrats/2014/09/16/991381b6-3cdf-11e4-9587-

5dafd96295f0 story.html?utm term=.fe06e15033c1>. Acesso em: 14 de agosto de 2017 (anotando que Obama "encabeçou dois arrecadadores para o Super PAC neste verão"). 116 Cf. Republican National Committee, et. al. v. Federal Electoral Commission, No. 1:14-cv00853 (D.D.C., May 23, 2014), Plaintiffs' Complaint for Declaratory and Injunctive Relief. Disponível em: $<$ http://www.fec.gov/law/litigation/rnc rnc complaint.pdf $>$. Acesso em: 14 de agosto de 2017. 
constitucional de receber contribuições ilimitadas dedicadas apenas para gastos de partido independente em nome de candidatos, então provavelmente veríamos uma inversão significativa do fluxo de dinheiro de Super PAC para os partidos.

A recente decisão da Suprema Corte no caso McCutcheon já poderia dar um suave empurrão nessa direção. ${ }^{117}$ Essa decisão deixou limites de contribuição intactos sobre o montante que um indivíduo poderia doar para qualquer candidato em particular ou para um partido político, mas invalidou limites sobre o valor total de dinheiro que um indivíduo (dentro destes limites) poderia dar a um grupo de candidatos ou organizações partidárias. Antes da decisão, um indivíduo não podia dar mais do que US\$ 123.200 no total para candidatos e organizações partidárias.118 A decisão desencadeou a formação de mais comissões conjuntas de arrecadação de fundos, que permitem que um grupo de candidatos possa coletar dinheiro coletivamente e aceitar uma única doação, que é então dividida legalmente entre os candidatos; além de permitir que organizações de partidos políticos, como uma organização partidária nacional e um número de organizações de partidos estaduais, façam a mesma coisa. ${ }^{119}$ Apesar das afirmações sobre o adicional de dinheiro que $\mathrm{McC}$ utcheon iria liberar através desses veículos, ainda não está claro, nesta fase, quanto dinheiro esses comitês conjuntos de captação de recursos serão capazes de arrecadar. ${ }^{120}$ Mas se os comitês conjuntos de arrecadação de fundos partidários se revelarem de grande importância prática, então o efeito de $M c C u t c h e o n$ provavelmente seria dar mais dinheiro para os partidos políticos, e não para organizações não partidárias, que nunca estiveram sujeitas a limites de contribuição como esses. Se isso ocorrer, $\mathrm{McC}$ utcheon acabaria por ser a primeira decisão da

117 McCutcheon v. Federal Election Commission, 134 S.Ct. 1434 (2014).

${ }_{118}$ McCutcheon v. Federal Election Commission, 134 S.Ct. 1434, 1443 (2014).

119 MAYERSOHN, Andrew. Gather Ye Contributions, In Bulk. OpenSecrets.Org:

Center for Responsive Politics, Aug. 21, 2014. Disponível em:

$<$ https://www.opensecrets.org/news/2014/08/gather-ye-contributions-in-bulk/>. Acesso em: 14 de agosto de 2017.

${ }^{120}$ MAYERSOHN, Andrew. Gather Ye Contributions, In Bulk. OpenSecrets.Org:

Center for Responsive Politics, Aug. 21, 2014. Disponível em:

$<$ https://www.opensecrets.org/news/2014/08/gather-ye-contributions-in-bulk/>. Acesso em: 14 de agosto de 2017; BIERSACK, Robert. McCutcheon Decision: Add Some More Zeroes to That Check. OpenSecrets.Org: Center for Responsive Politics, Apr. 2, 2014. Disponível em: $<$ http://www.opensecrets.org/news/2014/04/mccutcheon-decision-addsome-more-z>. Acesso em: 14 de agosto de 2017. 
Suprema Corte nesse campo, com o efeito prático de criar incentivos para que o dinheiro fluísse para os partidos e não para grupos não partidários. Qualquer outra coisa que pudesse ser dita sobre a decisão, seria, portanto, encorajar, em certa medida, as forças que induzem a centralização do financiamento através dos partidos - enfatizadas neste aspecto. ${ }^{121}$

Certamente, ainda há razão para se preocupar com o papel de grandes doações de indivíduos ou entidades individuais nas eleições americanas. Mas só começamos a tentar regulamentar o papel do dinheiro nas eleições nacionais de forma abrangente ${ }^{122}$ na década de 1970. Além disso, quase meio século de esforço usando essa abordagem mostrou que é extremamente difícil limitar a quantidade de dinheiro até que tenhamos um sistema de financiamento privado e uma compreensão da Primeira Emenda que impeça limitações sobre o gasto eleitoral - uma restrição da Primeira Emenda atribuível a Buckley v. Valeo ${ }^{123}$, e não a qualquer outra decisão mais recente. À luz desta realidade, a melhor política que podemos conseguir é, provavelmente, criar incentivos para encorajar este dinheiro a ser canalizado em uma direção e não em outra. Devemos usar esses incentivos para canalizar esse dinheiro para que ele flua através dos partidos políticos em um grau muito maior do que atualmente acontece.

\section{TORNANDO AS NEGOCIAÇÕES POSSÍVEIS}

Concentrei-me nas leis de financiamento de campanha apenas como um ponto de partida para meu tema maior: a necessidade de revigorar a capacidade dos líderes partidários de desempenhar um papel de liderança unificador. Se transformarmos os esforços de reforma nessa direção, em vez dos caminhos mais defendidos, então outras sugestões podem começar a surgir em mente.

Por exemplo, uma governança eficaz requer inevitavelmente negociações, em particular no nosso sistema de separação de poderes.

${ }^{121}$ Para uma visão similar, cf. PERSILY, Nathaniel. Bringing Big Money Out of the Shadows. The New York Times, Apr. 2, 2014. Disponível em:

$<$ http://www.nytimes.com/2014/04/03/opinion/bringing-big-money-out-of-theshadows.html>. Acesso em: 14 de agosto de 2017.

122 Para uma breve história da regulação do financiamento de campanhas, cf. ISSACHAROFF, Samuel; KARLAN, Pamela; PILDES, Richard. The Law of

Democracy: Legal Structure of the Political Process. 4th ed. Westbury, NY: Foundation Press, 2012, p. 332-334.

${ }^{123}$ Buckley v. Valeo, 424 U.S. 1 (1976). 
Mas há pouco no trabalho acadêmico sobre a democracia, ou até mesmo em relatos populares da democracia, que sequer abordam questões relacionadas à negociação, como os ambientes institucionais ou condições estruturais que permitem negociações efetivas entre os líderes políticos. Como as leis e as políticas poderiam facilitar essas estruturas e condições?

Parte de nossa romantização da democracia se refletiu em uma ênfase extrema em maior transparência como uma solução para nossas ansiedades democráticas. Em nossa cultura, é difícil defender a necessidade de sigilo nas negociações. Mas compare o ambiente em que as negociações internacionais bem-sucedidas ainda funcionam hoje (pelo menos antes da WikiLeaks) às maneiras pelas quais nossas leis e cultura de transparência transformaram o ambiente no qual as negociações domésticas sobre a política ocorrem.

Depois que o Governo de 1976 no Sunshine Act exigiu que as reuniões do comitê do Congresso fossem públicas, as pesquisas de senadores logo concluíram que esses requisitos de reunião aberta eram a maior causa de um declínio na capacidade de negociar e de fazer tradeoffs politicamente difíceis. ${ }^{124}$ Hoje, Temos o infeliz Federal Advisory Committee Act ${ }^{125}$, que amplia esses requisitos de reuniões abertas mesmo para órgãos que apenas dão conselhos ao governo federal e amarram esses grupos consultivos por pouco benefício público significativo. Se as negociações entre os líderes são uma chave para a governança efetiva, particularmente em tempos polarizados, então precisamos de um senso menos moralista e mais realista das condições nas quais as negociações efetivamente ocorrem.

Uma condição estrutural para a negociação produtiva na teoria e na prática é provavelmente a presença de atores políticos de longo prazo que irão interagir ao longo de negociações múltiplas. Os jogos de barganha individuais são notoriamente mais propensos à retenção estratégica e manipulação de informações, uma vez que não há ameaça de sanção

124 EHRENHALT, Alan. Special Report: The Individualist Senate. Congressional Quarterly Weekly Report, Sep. 4, 1982, p. 2177-2178 ("A maioria dos Senadores parece concordar que [os recentes requisitos de reunião aberta] tornaram a negociação e o sacrifício político infinitamente mais difíceis."). Cf., ainda, BINDER, Sarah; LEE, Frances. Making Deals in Congress. In: Jane Mansbridge; Cathie Jo Martin (eds.). Negotiating Agreement in Politics. Washington, DC: American Political Science Association, 2013, p. 58/63-64 (explicando como a transparência aumenta os incentivos a legisladores para que mantenham postura e torna mais difícil a análise de soluções mais amplas)

${ }^{125}$ Federal Advisory Committee Act, Public Law No. 92-463, 86 Stat. 770 (1972) (codificado como emenda a 5 U.S.C. app. §\$1-16 (2013)). 
futura em outras negociações. No plano político, isso sugere que, independentemente das desvantagens para as incumbências de longo prazo, uma vantagem que os membros do Congresso com mais tempo de serviço provavelmente terão é maior conhecimento informacional sobre o que o outro lado mais valoriza e o que ele pode se dar ao luxo de negociar; quais as ameaças são realistas e quais são blefes; e a capacidade de trocar questões em tempo e espaços políticos - uma habilidade que pode permitir um compromisso produtivo. ${ }^{26}$ Mais uma vez, a presença de atores de longo prazo é uma condição estrutural que tende a favorecer o papel dos líderes partidários, uma vez que eles tendem a ter atuado por mais tempo, juntamente com outros membros mais antigos.

Esta é mais uma razão por que as mudanças que dão poder aos recémchegados ao Congresso também podem dificultar a elaboração de acordos entre linhas partidárias. É certo que assentos homogêneos e seguros podem render uma longa série de mandatos para os candidatos que podem recorrer a polos mais extremos do espectro sem um custo eleitoral; mais uma vez, enfrentamos trocas entre valores democráticos. Mas a importância de repetir os atores para uma efetiva negociação democrática nos órgãos legislativos traz uma desvantagem para outra "reforma" populista romântica, mas contraproducente, do processo democrático: o movimento por limites de mandato (especialmente os curtos) para os legisladores estaduais. É o esforço para eleger mais "legisladores cidadãos". ${ }^{127}$ No entanto, os limites de mandato parecem não ter qualquer efeito sobre a composição dos eleitos para o cargo. ${ }^{128} \mathrm{O}$ esforço de fazer um mandato com tempo limitado também foi projetado para tornar os legisladores mais responsáveis perante o público. No entanto, o efeito dos limites de mandato é "enfraquecer o poder legislativo em relação ao executivo"129; capacitar o pessoal legislativo, que pode investir no desenvolvimento a longo prazo de competências de

${ }^{126}$ Cf. WARREN, Mark; MANSBRIDGE, Jane. Deliberative Negotiation. In: Jane Mansbridge; Cathie Jo Martin (eds.). Negotiating Agreement in Politics. Washington, DC: American Political Science Association, 2013, p. 104-106.

127 Para o papel retórico do "cidadão legislador" na defesa de limitação dos mandatos, cf. CAREY, John, et. al.. The Effects of Term Limits on State Legislatures: A New Survey of the 50 States. Legislative Studies Quarterly, Vol. 31, 1, 2006, p. 116. A Suprema Corte sustentou que as limitações legal dos mandatos para agentes federais são inconstitucionais em U.S. Term Limits, Inc. v. Thornton, 514 U.S. 779 (1995).

${ }^{128}$ CAREY, John, et. al.. The Effects of Term Limits on State Legislatures: A New Survey of the 50 States. Legislative Studies Quarterly, Vol. 31, 1, 2006, p. 113-117.

${ }^{129}$ CAREY, John, et. al.. The Effects of Term Limits on State Legislatures: A New Survey of the 50 States. Legislative Studies Quarterly, Vol. 31, 1, 2006, p. 129-130. 
formulação de políticas; para estimular os grupos de interesse, sobre os quais os legisladores menos experientes se tornam mais dependentes da informação; e para forçar os legisladores a adotar horizontes de tempo mais curtos, que estão em tensão com o longo prazo, e repetir as interações que levam a uma efetiva negociação política e à resolução de problemas. ${ }^{130}$

Uma segunda condição estrutural para a negociação efetiva entre divisões políticas, conforme sugerido acima, é a capacidade de certas etapas do processo de discussão e negociação acontecerem fora do olhar do público. De fato, ao contrário da ênfase popular na onipresente importância da transparência total, estudos sobre essa questão agora levam os principais relatórios de ciências sociais a emitir declarações tão fortes que "a evidência empírica sobre os benefícios deliberativos das interações de portas fechadas parece incontestável". ${ }^{131}$ Talvez as razões disso sejam óbvias, mas merecem uma breve menção, dada a maior ênfase que os benefícios "democráticos" da transparência têm recebido nas últimas décadas. Quando a plateia para uma negociação é pública, os partidos são encorajados a se posicionar para os seus próprios eleitores e, por vezes, a defender o princípio, recusando compromissos. Quando as negociações ocorrem em arenas menos públicas, os partidos geralmente se sentem livres para assumir maiores riscos em revelar suas posições, as questões sobre as quais têm preferências mais intensas, as questões sobre as quais podem dar e os benefícios que devem obter em troca de quaisquer compromissos que façam. Da mesma forma, as negociações funcionam como parte de pacotes de compensações, mas revelar qualquer compromisso potencial isoladamente, antes que todo o pacote de compromissos de compensação tenha sido acordado, pode facilmente destruir qualquer acordo potencial. É por essa razão que, naturalmente, uma táctica eficaz para desmantelar as negociações é fugir aos detalhes de uma possível dimensão de compromisso antes de se ter resolvido toda a gama de disposições. As negociações abertas podem por si mesmas fomentar a polarização, razão pela qual as negociações de paz são frequentemente realizadas em segredo. ${ }^{132}$

${ }^{130}$ Para o estudo mais abrangente dos efeitos das limitações de mandatos, cf., em geral, KOUSSER, Thad. Term Limits and the Dismantling of State Legislative

Professionalism. Cambridge, MA: Cambridge University Press, 2005.

${ }^{131}$ WARREN, Mark; MANSBRIDGE, Jane. Deliberative Negotiation. In: Jane Mansbridge; Cathie Jo Martin (eds.). Negotiating Agreement in Politics. Washington, DC: American Political Science Association, 2013, p. 108.

132 Para uma abordagem recente do papel do sigilo nas negociações de Camp David, durante o governo Carter, que produziram o tratado de paz entre Israel e Egito, cf. 
A exigência de maior transparência tem sido impulsionada, naturalmente, por preocupações genuinamente democráticas, incluindo preocupações com negócios corruptos - que não levam devidamente em conta toda a gama de interesses apropriados - ou preocupações de que interesses importantes afetados não irão ser ouvidos. Uma forma de reformular os custos e os benefícios da transparência para a democracia poderia, portanto, centrar-se menos na exigência de plena transparência dos processos e mais em pedir para a transparência das razões e propósitos que explicam e justificam os resultados. ${ }^{133}$

A adoção da Constituição fornece um exemplo: enquanto as negociações na Convenção Constitucional foram mantidas em segredo, houve um sólido debate público de ratificação, no qual as justificativas de várias disposições e os argumentos contra foram amplamente testados em um processo aberto e prolongado. ${ }^{134}$ Naturalmente, qualquer decisão de permitir um espaço maior para a negociação democrática privada seria, ela própria, uma decisão que, na maioria dos contextos, teria de ser feita publicamente e ser publicamente justificada - embora existam alguns contextos em que mesmo o fato de que a negociação está ocorrendo pode ter que permanecer secreto inicialmente para ter qualquer chance de sucesso.

Além disso, isolar os processos de negociação de monitoramento público constante a um grau maior exigiria que os formuladores de políticas gerassem confiança no próprio processo de negociação. Isso pode, por sua vez, exigir a divulgação pública dos participantes no processo, a fim de assegurar que todos os interesses relevantes estejam representados, mas sem necessariamente revelar as propostas substanciais detalhadas e passo a passo no próprio processo de negociação. Há muitas questões controversas em jogo, com certeza, ao defender um espaço maior para menos espaços de negociação de políticas públicas. No entanto, precisamos começar a levar a sério a realidade de que a transparência total pode estar em considerável tensão com os

WRIGHT, Lawrence. Thirteen Days in September: Carter, Begin, and Sadat at Camp

David. New York, NY: Alfred A. Knopf, 2014.

${ }^{133}$ Esta é uma recomendação que faz o Grupo de Trabalhos sobre Negociações da Associação Americana de Ciência Política. WARREN, Mark; MANSBRIDGE, Jane. Deliberative Negotiation. In: Jane Mansbridge; Cathie Jo Martin (eds.). Negotiating Agreement in Politics. Washington, DC: American Political Science Association, 2013, p. 108-112.

${ }^{134}$ Cf., em geral, MAIER, Pauline. Ratification: the People Debate the Constitution, 1787-1788. New York, NY: Simon \& Schuster, 2010 (revendo o papel extensivo desempenhado pelo "We The People" nos debates de ratificação dos Estados). 
defensores de negociações produtivas e, portanto, uma governança democrática efetiva em tempos polarizados.

Uma terceira implicação de se afastar do modelo romantizado de governança democrática é a seguinte. Em poucos anos, aprendemos que o fim das metas eliminou um dos benefícios mais diretos que a liderança partidária poderia conferir aos membros recalcitrantes para gerar seu apoio a grandes legislações. ${ }^{135}$ Uma visão de democracia menos romântica e menos purista talvez também deva aceitar que certos tipos de pagamentos públicos paralelos - o logrolling é um exemplo, é claro são necessários para permitir o compromisso e a negociação necessários para que o governo funcione mais ou menos de maneira efetiva. A negociação bem-sucedida tira proveito de diferentes intensidades de preferências; os membros do Congresso que são moderadamente opostos ou indiferentes à legislação podem ter fortes preferências pelos benefícios

${ }^{135}$ Cf., por exemplo, HELDERMAN, Rosalind. Boehner Faces a Political Cliff over Budget Fracas in Washington. The Washington Post, Dec. 22, 2012. Disponível em: $<$ http://www.washingtonpost.com/politics/boehner-faces-a-political-cliff-over-budgetfracas-in-washington/2012/12/22/8301c280-4acd-11e2-9a42-d1ce6d0ed278 story.html>. Acesso em: 14 de agosto de 2017 (descrevendo como foi difícil para Boehner derrubar a legislação de "precipício fiscal" em parte por causa da eliminação de afetações); PALETTA, Damian. Breakdown Is New Norm in Spending Showdowns. The Wall Street Journal, Oct. 1, 2013. Disponível em: $<$ http://online.wsj.com/news/articles/SB10001424052702303643304579107683112139054> . Acesso em: 14 de agosto de 2017 (explicando como a "revolta pública" contra as afetações significa que a passagem de emendas prevendo despesas não será mais desobstruída); STEINHAUER, Jennifer. Last Shutdown a Lesson Lost on Capitol Hill. The New York Times, Sept. 28, 2013. Disponível em: $<$ http://www.nytimes.com/2013/09/29/us/politics/last-shutdown-a-lesson-lost-oncapitol-hill.html>. Acesso em: 14 de agosto de 2017 (atribuindo a falha do Congresso em aprovar qualquer emenda orçamentária antes do encerramento parcial da proibição das afetações); e SULLIVAN, Sean; BLAKE, Aaron. House GOP to Look at Immigration against Backdrop of Deep Divisions. The Washington Post, Jul. 9, 2013. Disponível em: $<$ http://www.washingtonpost.com/politics/house-gop-to-look-atimmigration-against-backdrop-of-deep-divisions/2013/07/09/9f1fd7e6-e8a6-11e2-8f22de4bd2a2bd39 story.html >. Acesso em: 14 de agosto de 2017 (líderes partidários citando a perda das afetações como uma contribuição à redução na unidade de seu partido). O clássico estudo do papel dos "pork barrel projects" na construção de eficientes coalizões majoritárias no Congresso é EVANS, Diana. Greasing the Wheels: Using Pork Barrel Projects to Build Majority Coalitions in Congress. Cambridge, MA: Cambridge University Press, 2004. 
concentrados do que os projetos públicos em seu estado ou distritos oferecem. A proibição de trazer certas dimensões da política para a dinâmica de negociação pode dificultar tradeoffs e compromissos produtivos.

\section{VISÕES MENOS ROMANTIZADAS DA DEMOCRACIA}

Deixe-me voltar para onde eu comecei. Por muitos anos, a pesquisa de direito privado tem se concentrado nas consequências de suas regras para a dinâmica do poder privado em contextos como as do mercado. $\mathrm{O}$ meu objetivo e o que eu considero como o objetivo do "direito da democracia" é fazer o mesmo com o direito público, no contexto das eleições democráticas e da governança.

Esta abordagem recomenda que pensemos em termos de medidas que encorajem as forças de autoridade centralizada dentro dos partidos políticos e desencorajem as forças de fragmentação política. Os partidos mais fortes provavelmente irão continuar a ser o veículo mais eficaz para permitir os compromissos e negócios que são necessários tendo em vista a atual polarização dos partidos no governo. Dito de outra forma, o problema não é que tenhamos partidos parlamentares; é, em minha opinião, que nossos partidos políticos não são parlamentares - não o suficiente.

Os obstáculos a quaisquer mudanças nessa linha não serão meramente interesses enraizados. Para ultrapassar estes obstáculos, será igualmente necessário e importante enfrentar frontalmente duas poderosas tendências culturais que gerarão resistência às eleições financiadas publicamente através dos partidos e outras medidas que visem o re-empoderamento dos líderes políticos.

A primeira é a ideologia excepcional e distinta dos EUA de "participação popular". Qualquer mudança no sistema democrático que visa capacitar os líderes políticos será lançada em termos de conflito maniqueísta entre "o povo" e "as elites". A compreensão americana da democracia sempre invocou uma retórica da "soberania popular", que é muito mais populista do que em outras democracias ocidentais. Mas é cada vez mais evidente, pelo menos em nossa época, que a participação muito maior permitida pela revolução da comunicação gera polarização e fragmentação. Em vez de ver uma implacável expansão das reformas participativas como a cura para o que afeta a democracia, devemos começar a reconhecer uma troca talvez trágica entre o desejo de tornar o governo mais responsável, através de medidas como o aumento da participação popular e a capacidade do governo para funcionar de 
maneira mais eficaz. No passado, por exemplo, apoiei sistemas de financiamento de eleições públicas e privadas, como o sistema usado na cidade de Nova Iorque, e agora está sendo adotado em outros lugares. Mas, pelas razões que discuti anteriormente, fiquei preocupado que os sistemas só exacerbariam a polarização e a fragmentação. De fato, um estudo recente descobriu que nos sistemas de financiamento público de "dinheiro limpo", como os sistemas que combinam o dinheiro público com as contribuições privadas, as posições dos candidatos afastam-se do centro ideológico das preferências de política pública, uma vez que o sistema monetário foi adotado. ${ }^{136} \mathrm{O}$ mecanismo envolvido, como sugere o estudo, é a necessidade dos candidatos recorrerem a doadores individuais ideologicamente extremos para se qualificarem para fundos públicos. Outros estudos não chegam a tais conclusões ${ }^{137}$, e é muito cedo para tirar conclusões sobre se os sistemas de financiamento público baseados em doadores individuais contribuirão para a polarização. Contudo, devemos estar atentos à possibilidade de que o façam e não devemos dar por certo que os sistemas de financiamento público baseados em doadores refletirão inevitavelmente e automaticamente a distribuição real das preferências políticas entre o eleitorado geral.

Em segundo lugar, os esforços para capacitar a liderança partidária correrão para a desconfiança característica e única dos Estados Unidos nos partidos políticos. Parte da compreensão culturalmente distintiva da "soberania popular" nos Estados Unidos tem sido uma visão romanticamente individualista da democracia: uma visão que vê intermediários organizacionais entre cidadãos e governo, como os partidos políticos, como uma corrupção da verdadeira democracia. Além disso, se os partidos devem ser tolerados, então eles devem ser colocados sob o controle do "povo", tanto quanto possível; daí a Era Progressista, criação antipartidária da eleição primária obrigatória. Portanto, uma defesa ideológica robusta dos partidos políticos, bem como da liderança partidária e política, terá de ser empreendida de forma voluntária e direta, a fim de mobilizar o apoio para qualquer conjunto de medidas

${ }^{136}$ Cf. HALL, Andrew. How the Public Funding of Elections Increases Candidate Polarization. Working Paper. 2014, p. 20-21. Disponível em:

$<$ http://www.andrewbenjaminhall.com/Hall publicfunding.pdf $>$. Acesso em: 14 de agosto de 2017.

${ }^{137}$ Cf. MASKET, Seth; MILLER, Michael, Does Public Election Funding Create More Extreme Legislators? Evidence from Arizona and Maine. Working Paper. 2014.

Disponível em: < https://430327f0-a-62cb3a1a-s-

sites.googlegroups.com/site/millerpolsci/docs/extremismweb.pdf $>$. Acesso em: 14 de agosto de 2017. 
práticas que busquem re-empoderar a liderança partidária.

Se eu estiver certo de que o problema é a governança eficaz; de que a fragmentação política poderia ser um foco mais produtivo para esforços de reforma eficaz do que a polarização per se; e que a direção certa para um pensamento novo é como recapacitar líderes políticos e partidários, então também é necessário compreender as fontes profundas de resistência que devem ser engajadas como prelúdio de qualquer movimento prático nesse caminho. Essas fontes estão no apego distintamente americano a uma visão romântica da democracia centrada no cidadão individual, e não na governança efetiva e no papel central do poder político organizado, particularmente os partidos políticos, na determinação de como um sistema democrático realmente funciona na prestação do nível adequado e formas de bens públicos.

\section{Conclusão}

A democracia americana sempre se apoiou num equilíbrio entre uma mitologia da "soberania popular" e a realidade do que é necessário para organizar de maneira eficaz o poder político e de governo. A chave para uma democracia eficaz pode ser expressa da seguinte maneira: precisamos sustentar os elementos apropriados de participação popular, mantendo ao mesmo tempo uma estrutura coerente e decisiva de liderança política para permitir uma governança efetiva.

Devemos ter cuidado para não sermos seduzidos por uma concepção excessivamente romântica e individualizada de democracia que tenha uma ressonância mais profunda na cultura política e na história americana do que em qualquer outra nação. Devemos também ter cuidado em invocar valores democráticos, como a igualdade política, a liberdade de associação e de expressão, e a participação, em termos excessivamente idealizados e abstratos, que não atendem às consequências reais da institucionalização desses valores em formas particulares de poder político efetivo e governança. Este é um risco particular para a erudição jurídica e advocacia, que tendem a basear-se mais na análise e argumentação sobre valores e princípios do que sobre fatos empíricos sobre a organização real do poder político efetivo.

Eu percebo que não haverá aplausos para nada disto. Quem aplaude por centralizar mais poder nos partidos políticos num momento em que os partidos estão menos atraentes? Quem aplaude, pior ainda, uma visão particularmente elitista dos partidos políticos, centrada na capacitação dos líderes partidários? As pessoas não "vão às ruas" em favor dos partidos políticos e das elites partidárias. Tudo isso vai contra o DNA da 
sensibilidade democrática dos EUA.

Mas isso é parte do meu propósito: desafiar essas sensibilidades. No meio do declínio da governabilidade da ordem democrática americana, devemos nos concentrar menos na "participação" como a solução mágica e mais na dinâmica real de como facilitar a organização de um poder político efetivo. Tentei, hoje, dar-lhe um vislumbre dessa abordagem alternativa e institucionalista à democracia e ao pensamento jurídico.

\section{REFERÊNCIAS}

\section{ABRAMOWITZ, Alan. The Disappearing Center: Engaged Citizens,} Polarization, and American Democracy. New Haven, CT: Yale University Press, 2010.

ACKERMAN, Bruce; AYRES, Ian. Voting with Dollars: a New Paradigm for Campaign Finance. New Haven, CT: Yale University Press, 2002.

ANZIA, Sarah. Timing \& Turnout: How Off-Cycle Elections Favor Organized Groups. Chicago, IL: University of Chicago Press, 2014.

BAFUMI, Joseph; HERRON, Michael. Leapfrog Representation and Extremism: A Study of American Voters and Their Members in Congress. American Political Science Review, Vol. 104, 3, 2010.

BAILEY, Michael. Is Today's Court the Most Conservative in Sixty Years? Challenges and Opportunities in Measuring Judicial Preferences. Journal of Politics, Vol. 75, 3, 2013.

BALKIN, Jack. The Last Days of Disco: Why the American Political System Is Dysfunctional. Boston University Law Review, Vol. 94, 3, 2014. 
BALL, Molly. How the GOP Establishment Tea-Partied the Tea Party. The Atlantic, Nov. 6, 2013. Disponível em:

$<$ http://www.theatlantic.com/politics/archive/2013/11/how-the-gopestablishment-tea-partied-the-tea-party/281208>. Acesso em: 14 de agosto de 2017.

BARBER, Michael. Ideological Donors, Contribution Limits, and the Polarization of State Legislatures. Working Paper. 2013. Disponível em: $<$ http://citeseerx.ist.psu.edu/viewdoc/download?doi=10.1.1.668.8067\&re $\mathrm{p}=\mathrm{rep} 1 \&$ type $=\mathrm{pdf}>$. Acesso em: 14 de agosto de 2017.

. Representing the Preferences of Voters, Partisans, and Donors in the U.S. Senate. Working Paper. 2014, p. 18. Disponível em: $<$ http://citeseerx.ist.psu.edu/viewdoc/download?doi=10.1.1.668.1643\&re $\mathrm{p}=$ rep1\&type $=\mathrm{pdf}>$. Acesso em: 14 de agosto de 2017.

BARBER, Michael; McCARTY, Nolan. Causes and Consequences of Polarization. In: Jane Mansbridge; Cathie Jo Martin (eds.). Negotiating Agreement in Politics. Washington, DC: American Political Science Association, 2013.

BARRY, Francis. Forget the Dictionary, Super PACs aren't New. Bloomberg View, Mar. 21, 2014.

BAUER, Robert. Coordinating with a Super PAC, Raising Money for It, and the Difference between the Two. More Soft Money Hard Law, Jan. 27, 2014. Disponível em:

$<$ http://www.moresoftmoneyhardlaw.com/2014/01/coordinating-superpac-raising-money-difference-two>. Acesso em: 14 de agosto de 2017.

. Of Fragmentation and Networks, and the State of Political Parties. More Soft Money Hard Law, Feb. 19, 2014. Disponível em: $<$ http://www.moresoftmoneyhardlaw.com/2014/02/fragmentationnetworks-state-political-parties>. Acesso em: 14 de agosto de 2017. 
. The Right to "Do Politics" and Not Just To Speak: Thinking About the Constitutional Protections for Political Action. Duke Journal of Constitutional Law \& Public Policy, Vol. 9, 1, 2013.

BIERSACK, Robert. McCutcheon Decision: Add Some More Zeroes to That Check. OpenSecrets.Org: Center for Responsive Politics, Apr. 2, 2014. Disponível em:

$<$ http://www.opensecrets.org/news/2014/04/mccutcheon-decision-addsome-more-z $>$. Acesso em: 14 de agosto de 2017.

BINDER, Sarah; LEE, Frances. Making Deals in Congress. In: Jane Mansbridge; Cathie Jo Martin (eds.). Negotiating Agreement in Politics. Washington, DC: American Political Science Association, 2013.

BLACK, Earl; BLACK, Merle. The Rise of Southern Republicans. Cambridge, MA: Harvard University Press, 2002.

BONICA, Adam. Ideology and Interests in the Political Marketplace. American Journal of Political Science, Vol. 57, 2, 2013.

. Mapping the Ideological Marketplace. American Journal of Political Science, Vol. 58, 2, 2014.

BONNEAU, Chris; GANN HALL, Melinda. In Defense of Judicial Elections. New York, NY: Routledge, 2009.

BRIFFAULT, Richard. Soft Money, Issue Advocacy, and the U.S. Campaign Finance Law. Elections Canada, May, 2002. Disponível em: $<$ http://www.elections.ca/content.aspx?section=res\&dir=eim/issue5\&doc ument=p3\&lang=e $>$. Acesso em: 14 de agosto de 2017.

. Super PACs. Minnesota Law Review, Vol. 96, 5, 2012. 
. The Political Parties and Campaign Finance Reform. Columbia Law Review, Vol. 100, 3, 2000.

BROOCKMAN, David. An Artificial "Disconnect"? Assuming Americans Are Reliably Ideological Masks Public Support for Policies More Extreme than Politicians Pursue. Manuscrito não publicado, 2014.

CALOMIRIS, Charles; HABER, Stephen. Fragile by Design: the Political Origins of Banking Crises \& Scarce Credit. Princeton, NJ: Princeton University Press, 2014.

CAREY, John, et. al.. The Effects of Term Limits on State Legislatures: A New Survey of the 50 States. Legislative Studies Quarterly, Vol. 31, 1, 2006.

CAREY, Maeve. Presidential Appointments, The Senate's Confirmation Process, and Changes Made in the 112th Congress. Congressional Research Service, CRS Report 41872, 2012.

CARSEY, Thomas; LAYMAN, Geoffrey. Our Politics Is Polarized on More Issues than Ever Before. The Washington Post, Jan. 17, 2014. Disponível em: $<$ http://www.washingtonpost.com/blogs/monkeycage/wp/2014/01/17/our-politics-is-polarized-on-more-issues-than-everbefore $>$. Acesso em: 14 de agosto de 2017.

CHARLES, Guy-Uriel. Judging the Law of Politics. Michigan Law Review, Vol. 103, 6, 2005 (resenha de HASEN, Richard. The Supreme Court and Election Law: Judging Equality from Baker v. Carr to Bush v. Gore. New York, NY: New York University Press, 2003).

CHEN, Jowei; RODDEN, Jonathan. Don't Blame the Maps. The New York Times, Jan. 24, 2014. Disponível em:

$<$ http://www.nytimes.com/2014/01/26/opinion/sunday/its-thegeography-stupid.html>. Acesso em: 14 de agosto de 2017. 
COOPER, Brad. New PAC Supports Moderate Kansas Republicans. The Wichita Eagle, Aug. 1, 2012. Disponível em:

$<$ http://www.kansas.com/2012/08/01/2432145/new-pac-supportsmoderate-kansas.html>. Acesso em: 14 de agosto de 2017.

COX, Gary; McCUBBINS, Mathew. Legislative Leviathan: Party Government in the House. Berkeley, CA: University of California Press, 1993.

CROLEY, Steven. The Majoritarian Difficulty: Elective Judiciaries and the Rule of Law. University of Chicago Law Review, Vol. 62, 2, 1995.

DAVE, Paresh. SEIU California Launches Republican PAC to Back Moderates. The Sacramento Bee, Jun. 9, 2011. Disponível em: $<$ http://blogs.sacbee.com/capitolalertlatest/2011/06/seiu-californiarepublican-pac.html>. Acesso em: 14 de agosto de 2017.

DWORKIN, Ronald. Taking Rights Seriously. Cambridge, MA: Harvard University Press, 1977.

EGGEN, Dan. Outside Groups Plan To Focus on Air War, Ground Game in 2012 Election Fight. The Washington Post, Apr. 20, 2012. Disponível em: $<$ http://www.washingtonpost.com/politics/outsidegroups-plan-to-focus-on-air-war-ground-game-in-2012-electionfight/2012/04/20/gIQAw6beWT story.html $>$. Acesso em: 14 de agosto de 2017.

EHRENHALT, Alan. Special Report: The Individualist Senate. Congressional Quarterly Weekly Report, Sep. 4, 1982.

EPSTEIN, Leon. Political Parties in the American Mold. Madison, WI: University of Wisconsin Press, 1986. 
EVANS, Diana. Greasing the Wheels: Using Pork Barrel Projects to Build Majority Coalitions in Congress. Cambridge, MA: Cambridge University Press, 2004.

FIORIAN, Morris. Americans Have Not Become More Polarized. The Washington Post, Jun. 23, 2014. Disponível em:

$<$ http://www.washingtonpost.com/blogs/monkeycage/wp/2014/06/23/americans-have-not-become-more-politicallypolarized $>$. Acesso em: 14 de agosto de 2017.

FRANCIA, Peter, et. al.. The Financiers of Congressional Elections: Investors, Ideologues, and Intimates. New York, NY: Columbia University Press, 2003.

FRUM, David. The Transparency Trap: Why Trying to Make Government More Accountable Has Backfired. The Atlantic, Aug. 13, 2014. Disponível em:

$<$ http://www.theatlantic.com/magazine/archive/2014/09/thetransparency-trap/375074>. Acesso em: 14 de Agosto de 2017.

GARLAND, David. Peculiar Institution: America's Death Penalty in an Age of Abolition. Cambridge, MA: Belknap Press of Harvard University Press, 2010.

GARRETT, Elizabeth. Voting with Cues. University of Richmond Law Review, Vol. 37, 4, 2003.

GERKEN, Heather. Second-Order Diversity. Harvard Law Review, Vol. 118, 4, 2005.

. What Election Law Has to Say to Constitutional Law? Indiana Law Review, Vol. 44, 1, 2011.

GIERZYNSKI, Anthony; BREAUX, David. The Financing Role of 
Parties. In: Joel Thompson; Gary Moncrief (eds.). Campaign Finance in State Legislative Elections. Washington, DC: Congressional Quarterly Inc., 1998.

GILMORE, Glenda Elizabeth. Gender and Jim Crow: Women and the Politics of White Supremacy in North Carolina, 1896-1920. Chapel Hill, NC: University of North Carolina, 1996.

GLUECK, Katie. King Launches PAC. The Global Politico, Dec. 16, 2013. Disponível em: $<$ http://www.politico.com/story/2013/12/peterking-pac-2016-election-101204.html >. Acesso em: 14 de agosto de 2017.

GOLD, Matea. Top Harry Reid Advisers Build Big-Money Firewall To Protect Senate Democrats. The Washington Post, Sept. 16, 2014.

Disponível em: $<$ https://www.washingtonpost.com/politics/top-harryreid-advisers-build-big-money-firewall-to-protect-senatedemocrats/2014/09/16/991381b6-3cdf-11e4-95875dafd96295f0 story.html?utm term=.fe06e15033c1>. Acesso em: 14 de agosto de 2017.

GROSE, Christian. The Adoption of Electoral Reforms and Ideological Change in the California State Legislature. Los Angeles, CA:

Schwarzenegger Institute of University of Southern California, 2014.

Disponível em: $<$ http://www.schwarzeneggerinstitute.com/images/SIAdoption\%20of\%20Electoral\%20Reforms\%20Report.pdf $>$. Acesso em: 14 de agosto de 2017.

GROSSMANN, Matt. Artists of the Possible: Governing Networks and American Policy Change since 1945. New York, NY: Oxford University Press, 2014.

HACKER, Jacob; PIERSON, Paul. Off Center: The Republican Revolution and the Erosion of American Democracy. New Haven, CT: Yale University Press, 2005. 
HAIDT, Jonathan; HETHERINGTON, Marc. Look How Far We've Come Apart. The New York Times, Sept. 17, 2012. Disponível em: $<$ http://campaignstops.blogs.nytimes.com/2012/09/17/look-how-farweve-come-apart>. Acesso em: 14 de agosto de 2017.

HALL, Andrew. How the Public Funding of Elections Increases Candidate Polarization. Working Paper. 2014, p. 20-21. Disponível em: $<$ http://www.andrewbenjaminhall.com/Hall publicfunding.pdf $>$. Acesso em: 14 de agosto de 2017.

HAMM, Keith, et. al.. Independent Spending in State Elections: Vertically Networked Political Parties Have Been the Real Story. Working Paper. 2014, p. 1. Disponível: $<$ http://www.cfinst.org/pdf/state/hamm-kettler-malbin-glavin stateindep-spdg 2006-2010 webversion.pdf $>$. Acesso em: 14 de agosto de 2017.

HASEN, Richard. Clipping Coupons for Democracy? An Egalitarian/Public Choice Defense of Campaign Finance Vouchers.

California Law Review, Vol. 84, 1, 1996.

. Super PAC Contributions, Corruption, and the Proxy War over Coordination. Duke Journal of Constitutional Law \& Public Policy, Vol. 9, 2, 2014.

. The Supreme Court and Election Law: Judging Equality from

Baker v. Carr to Bush v. Gore. New York, NY: New York University Press, 2003.

HEBERLIG, Eric, et. al.. The Price of Leadership: Campaign Money and the Polarization of Congressional Parties. Journal of Politics, Vol. 68, 4, 2006. 
HEBERLIG, Eric; LARSON, Bruce. Congressional Parties, Institutional Ambition, and the Financing of Majority Control. Ann Arbor, MI:

University of Michigan Press, 2012.

HELDERMAN, Rosalind. Boehner Faces a Political Cliff over Budget Fracas in Washington. The Washington Post, Dec. 22, 2012. Disponível em: $<$ http://www.washingtonpost.com/politics/boehner-faces-apolitical-cliff-over-budget-fracas-in-washington/2012/12/22/8301c2804acd-11e2-9a42-d1ce6d0ed278 story.html>. Acesso em: 14 de agosto de 2017.

HELLMANN, Deborah. Defining Corruption and Constitutionalizing Democracy. Michigan Law Review, Vol. 111, 8, 2013.

HERNANDEZ, Raymond. Bloomberg Starts 'Super PAC,' Seeking National Influence. The New York Times, Oct. 27, 2012. Disponível em: $<$ http://www.nytimes.com/2012/10/18/nyregion/bloomberg-formingsuper-pac-to-influence-2012-races.html $>$. Acesso em: 14 de agosto de 2017.

HETHERINGTON, Marc; RUDOLPH, Thomas. Why Don't Americans Trust the Government? Because the Other Party Is in Power. The Washington Post, Jan. 30, 2014. Disponível em: $<$ https://www.washingtonpost.com/news/monkeycage/wp/2014/01/30/why-dont-americans-trust-the-governmentbecause-the-other-party-is-in-power/?utm term=.fff2eee3a2d9>. Acesso em: 14 de agosto de 2017.

HOEY, Dennis. Eliot Cutler to Launch PAC for Moderates. Portland Press Herald, Mar. 30, 2011. Disponível em:

$<$ http://www.pressherald.com/news/cutler-to-launch-pac-formoderates 2011-03-30.html >. Acesso em: 14 de agosto de 2017.

HOFSTADTER, Richard. The Idea of a Party System: the Rise of 
Legitimate Opposition in the United States, 1780-1840. Berkeley, CA: University of California Press, 1970.

HOWE, Daniel Walker. What Hath God Wrought: the Transformation of America, 1815-1848. New York, NY: Oxford University Press, 2007.

ISSACHAROFF, Samuel. Is Section 5 of the Voting Rights Act a Victim of Its Own Success? Columbia Law Review, Vol. 104, 6, 2004.

ISSACHAROFF, Samuel; KARLAN, Pamela. The Hydraulics of Campaign Finance Reform. Texas Law Review, Vol. 77, 7, 1999.

ISSACHAROFF, Samuel; KARLAN, Pamela; PILDES, Richard. The Law of Democracy: Legal Structure of the Political Process. Westbury, NY: Foundation Press, 1998.

_____ The Law of Democracy: Legal Structure of the

Political Process. 4th ed. Westbury, NY: Foundation Press, 2012.

ISSACHAROFF, Samuel; PETERMAN, Jeremy. Special Interests After Citizens United: Access, Replacement, and Interest Group Response to Legal Change. Annual Review of Law and Social Science, Vol. 9, 1, 2013.

ISSACHAROFF, Samuel; PILDES, Richard. Politics as Markets:

Partisan Lockups of the Democratic Process. Stanford Law Review, Vol. 50, 3, 1998.

IYENGAR, Shanto, et. al.. Affect, Not Ideology: A Social Identity Perspective on Polarization. Public Opinion Quarterly, Vol. 76, 3, 2012.

JUDIS, John. The Paradox of American Democracy: Elites, Special Interests, and the Betrayal of Public Trust. New York, NY: Pantheon Books, 2000. 
KANG, Michael. Race and Democratic Contestation. Yale Law Journal, Vol. 117, 5, 2008.

. Sore Loser Laws and Democratic Contestation. Georgetown

Law Review, Vol. 99, 4, 2011.

KARLAN, Pamela. Georgia v. Ashcroft and the Retrogression of Retrogression. Election Law Journal: Rules, Politics, and Policy, Vol. 3, 1, 2004.

KATZNELSON, Ira. Fear Itself: The New Deal and the Origins of our Time. New York, NY: Liveright Publishing Corp., 2014.

KELNER, Robert; LA RAJA, Raymond. McCain-Feingold's Devastating Legacy. The Washington Post, Apr. 11, 2014. Disponível em: $<$ https://www.washingtonpost.com/opinions/mccain-feingoldsdevastating-legacy/2014/04/11/14a528e2-c18f-11e3-bcecb71ee10e9bc3 story.html?utm term $=.37 d 3 d 3181 \mathrm{f} 5 \mathrm{c}>$. Acesso em: $14 \mathrm{de}$ agosto de 2017.

KIEWIET, Roderick; McCUBBINS, Mathew. The Logic of Delegation: Congressional Parties and the Appropriations Process. Chicago, IL: Chicago University Press, 1991.

KING, Anthony. Running Scared: Why America's Politicians Campaign too much and Govern too little. New York, NY: Martin Kessler Books, 1997.

KING, JR., Neil. GOP Pushes Back on Tea Party. The Wall Street Journal, Oct. 9, 2013. Disponível em: $<$ https://www.wsj.com/articles/gop-pushes-back-on-tea-party$\underline{1381361910>}$. Acesso em: 14 de agosto de 2017. 
KLEIN, Ezra. Small Donors May Make Politics Even Worse. Minnesota Lawyer. 2013. Disponível em: $<$ http://minnlawyer.com/2013/05/10/ezraklein-small-donors-may-make-politics-even-worse/>. Acesso em: $14 \mathrm{de}$ agosto de 2017.

KOUSSER, Joseph Morgan. The Shaping of Southern Politics: Suffrage Restriction and the Establishment of the One-Party South, 1880-1910. New Haven, CT: Yale University Press, 1974.

KOUSSER, Thad. Term Limits and the Dismantling of State Legislative Professionalism. Cambridge, MA: Cambridge University Press, 2005.

KOUSSER, Thad, et. al.. Reform and Representation: Assessing California's Top-Two Primary and Redistricting Commission. Working Paper, 2013. Disponível em:

$<$ http://www.columbia.edu/ jhp2121/workingpapers/ReformAndRepres entation.pdf $>$. Acesso em: 14 de Agosto de 2017.

LA RAJA, Raymond; SCHAFFNER, Brian. Do Party-Centered Campaign Finance Laws Increase Funding for Moderates and Challengers? Working Paper. 2014.

___ Want to Reduce Polarization? Give Parties More Money. The Washington Post, Jul. 21, 2014. Disponível em: $<$ http://www .washingtonpost.com/blogs/monkey-cage/wp/2014/07/21/want-toreduce-polarization-give-parties-more-money $>$. Acesso em: 14 de agosto de 2017.

LEHOUCQ, Fabrice Edouard. Institutionalizing Democracy: Constraint and Ambition in the Politics of Electoral Reform. Comparative Politics, Vol. 32, 4, 2000.

LEONARD, Gerald. The Invention of Party Politics: Federalism, 
Popular Sovereignty, and Constitutional Development in Jacksonian Illinois. Chapel Hill, NC: University of North Carolina Press, 2002.

LESSIG, Lawrence. A Reply to Professor Hasen. Harvard Law Review, Vol. 126, 2, 2013.

LEVENDUSKY, Matthew. The Partisan Sort: How Liberals became Democrats and Conservatives became Republicans. Chicago, IL: Chicago University Press, 2009.

LEVINSON, Daryl; PILDES, Richard. Separation of Parties, Not Powers. Harvard Law Review, Vol. 119, 8, 2006.

LEVITIN, Adam. The Politics of Financial Regulation and the Regulation of Financial Politics: A Review Essay. Harvard Law Review, 127, 7, 2014.

LEWIS, David. The Politics of Presidential Appointments: Political Control and Bureaucratic Performance. Princeton, NJ: Princeton University Press, 2008.

LIPTON, Eric, et. al.. Business Groups See Loss of Sway over House G.O.P.. The New York Times, Oct. 9, 2013. Disponível em: $<$ http://www.nytimes.com/2013/10/10/us/business-groups-see-loss-ofsway-over-house-gop.html?pagewanted=all $>$. Acesso em: 14 de agosto de 2017.

MAIER, Pauline. Ratification: the People Debate the Constitution, 1787-1788. New York, NY: Simon \& Schuster, 2010.

MALBIN, Michael. Small Donors: Incentives, Economies of Scale, and Effects. Forum, Vol. 11, 3, 2013.

MASKET, Seth. Mitigating Extreme Partisanship in an Era of 
Networked Parties: an Examination of Various Reform Strategies. Center for Effective Public Management at Brookings Institution. 2014. Disponível em: $<$ http://www.brookings.edu/ /media/research/files/papers/2014/03/20masket/masket mitigating-extreme-partisanship-in-an-era-ofnetworked-parties.pdf $>$. Acesso em: 14 de agosto de 2017.

MASKET, Seth; MILLER, Michael, Does Public Election Funding Create More Extreme Legislators? Evidence from Arizona and Maine. Working Paper. 2014. Disponível em: $<\underline{\text { https://430327f0-a-62cb3a1a-s- }}$ sites.googlegroups.com/site/millerpolsci/docs/extremismweb.pdf >. Acesso em: 14 de agosto de 2017.

MAYERSOHN, Andrew. Gather Ye Contributions, In Bulk. OpenSecrets.Org: Center for Responsive Politics, Aug. 21, 2014. Disponível em: $<$ https://www.opensecrets.org/news/2014/08/gather-yecontributions-in-bulk/>. Acesso em: 14 de agosto de 2017.

McCARTY, Nolan, et. al.. Does Gerrymandering Cause Polarization? American Journal of Political Science, Vol. 53, 3, 2009.

McCARTY, Nolan, et. al.. Geography and Polarization. 2013. Disponível em: $<$ http://www.stanford.edu/ jrodden/wp/geo polar apsa2013 V4.pdf $>$. Acesso em: 14 de agosto de 2017.

McCARTY, Nolan, et. al.. Polarization is Real (and Asymmetric). Voteview Blog, May 16, 2012. Disponível em: $<$ http://themonkeycage.org/2012/05/polarization-is-real-andasymmetric/>. Acesso em: 14 de agosto de 2017.

McCARTY, Nolan, et. al.. Polarized America: the Dance of Ideology and Unequal Riches. Cambridge, MA: The MIT Press, 2006. 
McGHEE, Eric, et. al.. A Primary Cause of Partisanship? Nomination Systems and Legislator Ideology. American Journal of Political Science, Vol. 58, 2, 2014.

NAÍM, Moisés. The End of Power: From Boardrooms to Battlefields and Churches to States, Why Being in Charge Isn't What It Used to Be. New York, NY: Basic Books, 2013.

NASSMACHER, Karl-Heinz. Party Funding in Continental Western Europe. In: Reginald Austin; Maja Tjernström (eds.). Funding of Political Parties and Election Campaigns. Stockholms: International Institute for Democracy and Electoral Assistance, 2003.

NATIONAL CONFERENCE OF STATE LEGISLATURES. Overview of State Laws on Public Financing. 2013. Disponível em:

$<$ http://www.ncsl.org/research/elections-and-campaigns/publicfinancing-of-campaigns-overview.aspx $>$. Acesso em: 14 de agosto de 2017.

OHMAN, Magnus. Political Finance Regulations around the World: an Overview of the International IDEA Database. Stockholm:

International Institute for Democracy and Electoral Assistance, 2012.

PALETTA, Damian. Breakdown Is New Norm in Spending Showdowns. The Wall Street Journal, Oct. 1, 2013. Disponível em: $<$ http://online.wsj.com/news/articles/SB10001424052702303643304579107 683112139054>. Acesso em: 14 de agosto de 2017.

PERSILY, Nathaniel. Bringing Big Money Out of the Shadows. The New York Times, Apr. 2, 2014. Disponível em:

$<$ http://www.nytimes.com/2014/04/03/opinion/bringing-big-money-outof-the-shadows.html $>$. Acesso em: 14 de agosto de 2017.

. Soft Parties and Strong Money. Election Law Journal, Vol. 3, 2, 
2004.

. The Peculiar Geography of Direct Democracy: Why the Initiative, Referendum, and Recall Developed in the American West. Michigan Law \& Policy Review, Vol. 2, 1, 1997.

PEW RESEARCH CENTER. Political Polarization in the American Public: How Increasing Ideological Uniformity and Partisan Antipathy Affects Politics, Compromise, and Everyday Life. 2014. Disponível em: $<$ http://www.people-press.org/2014/06/12/politicalpolarization-in-the-american-public $>$. Acesso em: 14 de agosto de 2017.

PILDES, Richard. Competitive, Deliberative, and Rights-Oriented Democracy. Election Law Journal: Rules, Politics, and Policy, Vol. 3, 4, 2004 (resenha de POSNER, Richard. Law, Pragmatism, and Democracy. Cambridge, MA: Harvard University Press, 2003). . Democracy, Anti-Democracy and the Canon. Constitutional Commentary, Vol. 17, 2, 2000.

. Disputing Elections. In: Arthur Jacobson; Michael Rosenfeld (eds.). The Longest Night: Polemics and Perspectives on Election 2000. Berkeley, CA: University of California Review, 2002. . Foreword: The Constitutionalization of Democratic Politics. Harvard Law Review, Vol. 118, 29, 2004.

. Is Voting-Rights Law Now at War with Itself? Social Science and Voting Rights in the 2000s. North Carolina Law Review, Vol. 80, 5, 2002.

. Political Competition and the Modern VRA. In: David Epstein, et. al. (eds.). The Future of the Voting Rights Act. New York, NY:

Russell Sage Foundation, 2006. 
. The Politics of Race. Harvard Law Review, Vol. 108, 6, 1995 (resenha de DAVIDSON, Chandler; GROFMAN, Bernard. (eds.). Quiet Revolution in the South: the Impact of the Voting Rights Act, 19651990. Princeton, NJ: Princeton University Press, 1994).

. The Theory of Political Competition, Virginia Law Review, Vol. $85,8,1999$.

. Why the Center Does Not Hold: The Causes of Hyperpolarized Democracy in America. California Law Review, Vol. 99, 2, 2011.

PUTNAM, Robert. Bowling Alone: America's Declining Social Capital. Journal of Democracy, Vol. 6, 1, 1995.

RAHAT, Gideon. Candidate Selection: The Choice before the Choice. Journal of Democracy, Vol. 18, 1, 2007.

RANNEY, Austin. The Doctrine of Responsible Party Government: Its Origins and Present State. Urbana, IL: University of Illinois Press, 1954.

ROBERTSON, Campbell. Byrne Wins Republican Runoff in Alabama House Race. The New York Times, Nov. 5, 2013. Disponível em: $<$ http://www.nytimes.com/2013/11/06/us/politics/tea-party-republicanloses-alabama-runoff.html>. Acesso em: 14 de agosto de 2017.

ROHDE, David. Parties and Leaders in the Postreform House. Chicago, IL: University of Chicago Press, 1991.

ROSENBLUM, Nancy. On the Side of the Angels: an Appreciation of Parties and Partisanship. Princeton, NJ: Princeton University Press, 2008.

RUNCIMAN, David. The Confidence Trap: a History of Democracy in 
Crisis from World War I to the Present. Princeton, NJ: Princeton University Press, 2013.

SAMPLE, James, et. al. (eds.). The New Politics of Judicial Elections 2000-2009: decade of change. Washington, DC: Justice at Stake Campaign, 2010.

SCARROW, Susan, et. al.. From Social Integration to Electoral Contestation: The Changing Distribution of Power within Political Parties. In: Russell Dalton; Martin Watterberg (eds.). Parties without Partisans: Political Change in Advanced Industrial Democracies. Oxford: Oxford University Press, 2002.

SCHEIBER, Noam. Hillary's Nightmare? A Democratic Party That Realizes Its Soul Lies with Elizabeth Warren. New Republic, Nov. 10, 2013. Disponível em:

$<$ http://www.newrepublic.com/article/115509/elizabeth-warren-hillaryclintons-nightmare>. Acesso em: 14 de agosto de 2017.

SHOR, Boris; McCARTY, Nolan. The Ideological Mapping of American Legislatures. American Political Science Review, Vol. 105, 3, 2011.

SHUGERMAN, Jed Handelsman. The People's Courts: Pursuing Judicial Independence in America. Cambridge, MA: Harvard University Press, 2012.

SINCLAIR, Barbara. Party Wars: Polarization and the Politics of National Policy Making. Norman, OK: University of Oklahoma Press, 2006.

SMITH, Bradley. Super PACs and the Role of "Coordination" in Campaign Finance Law. Willamette Law Review, Vol. 49, 4, 2013.

STEINHAUER, Jennifer. Last Shutdown a Lesson Lost on Capitol Hill. 
The New York Times, Sept. 28, 2013. Disponível em:

$<$ http://www.nytimes.com/2013/09/29/us/politics/last-shutdown-alesson-lost-on-capitol-hill.html>. Acesso em: 14 de agosto de 2017.

STEPHANOPOULOS, Nicholas. Aligning Campaign Finance Law. Virginia law Review, Vol. 101, 5, 2015.

. Our Electoral Exceptionalism. University of Chicago Law

Review, Vol. 80, 2, 2013.

STEWART, Richard. The Reformation of American Administrative Law. Harvard Law Review, Vol. 88, 8, 1975.

STONECASH, Jeffrey, et. al.. Diverging Parties: Social Change, Realignment, and Party Polarization. Boulder, CO: Westview Press, 2003.

STRAUSS, Daniel. Super PAC to Defend Moderate Republicans against Tea Partiers. Talking Points Memo, Dec. 4, 2013. Disponível em: $<$ http://talkingpointsmemo.com/dc/defending-main-street-republicans $>$. Acesso em: 14 de agosto de 2017.

STUNTZ, William. The Collapse of American Criminal Justice. Cambridge, MA: Belknap Press of Harvard University Press, 2011.

SULLIVAN, Sean; BLAKE, Aaron. House GOP to Look at Immigration against Backdrop of Deep Divisions. The Washington Post, Jul. 9, 2013. Disponível em: $<$ http://www.washingtonpost.com/politics/house-gopto-look-at-immigration-against-backdrop-of-deepdivisions/2013/07/09/9f1fd7e6-e8a6-11e2-8f22de4bd2a2bd39 story.html>. Acesso em: 14 de agosto de 2017.

TOKAJI, Daniel. Responding to Shelby County: A Grand Election Bargain. Harvard Law \& Policy Review, Vol. 8, 1, 2014. 
TOLCHIN, Michael; TOLCHIN, Susan. To the Victor: Political Patronage from the Clubhouse to the White House. New York, NY: Random House, 1972.

WALLISON, Peter; GORA, Joel. Better Parties, Better Government: a Realistic Program for Campaign Finance Reform. Washington, DC: AEI Press, 2009.

WARREN, Mark; MANSBRIDGE, Jane. Deliberative Negotiation. In: Jane Mansbridge; Cathie Jo Martin (eds.). Negotiating Agreement in Politics. Washington, DC: American Political Science Association, 2013.

WEISMAN, Jonathan. In Mississippi, It's G.O.P. vs. Tea Party. The New York Times, Mar. 26, 2014. Disponível em:

$<$ http://www.nytimes.com/2014/03/27/us/politics/mississippi-senaterace-boils-down-to-gop-vs-tea-party.html >. Acesso em: 14 de agosto de 2017.

WHACK, Errin. Bolling Launches PAC to Recruit Mainstream Republicans in Virginia. The Washington Post, May 15, 2013. Disponível em: $<$ http://www.washingtonpost.com/local/vapolitics/bolling-announces-launch-of-pac-to-recruit-mainstreamrepublicans-in-virginia/2013/05/15/81b1a2bc-bd6c-11e2-89c93be8095fe767 story.html>. Acesso em: 14 de agosto de 2017.

WILENTZ, Sean. The Rise of American Democracy: Jefferson to Lincoln. New York, NY: Norton, 2005.

WRIGHT, Lawrence. Thirteen Days in September: Carter, Begin, and Sadat at Camp David. New York, NY: Alfred A. Knopf, 2014. 
Democracia Romantizada, Fragmentação Política e o Declínio do Governo Norte-Americano Romanticizing Democracy, Political Fragmentation, and the Decline of American Government Submetido em: 2017-07-11 Aceito em: 2017-07-29 